\title{
Monitoring of Double-Stud Wall Moisture Conditions in the Northeast
}

K. Ueno

Building Science Corporation

March 2015 


\title{
NOTICE
}

This report was prepared as an account of work sponsored by an agency of the United States government. Neither the United States government nor any agency thereof, nor any of their employees, subcontractors, or affiliated partners makes any warranty, express or implied, or assumes any legal liability or responsibility for the accuracy, completeness, or usefulness of any information, apparatus, product, or process disclosed, or represents that its use would not infringe privately owned rights. Reference herein to any specific commercial product, process, or service by trade name, trademark, manufacturer, or otherwise does not necessarily constitute or imply its endorsement, recommendation, or favoring by the United States government or any agency thereof. The views and opinions of authors expressed herein do not necessarily state or reflect those of the United States government or any agency thereof.

Available electronically at http://www.osti.gov/bridge

Available for a processing fee to U.S. Department of Energy and its contractors, in paper, from:

\author{
U.S. Department of Energy \\ Office of Scientific and Technical Information \\ P.O. Box 62 \\ Oak Ridge, TN 37831-0062 \\ phone: 865.576 .8401 \\ fax: 865.576.5728 \\ email: mailto:reports@adonis.osti.gov
}

Available for sale to the public, in paper, from:

U.S. Department of Commerce

National Technical Information Service

5285 Port Royal Road

Springfield, VA 22161

phone: 800.553 .6847

fax: 703.605.6900

email: orders@ntis.fedworld.gov

online ordering: http://www.ntis.gov/ordering.htm 


\title{
Monitoring of Double-Stud Wall Moisture Conditions in the Northeast
}

\author{
Prepared for: \\ The National Renewable Energy Laboratory \\ On behalf of the U.S. Department of Energy's Building America Program \\ Office of Energy Efficiency and Renewable Energy \\ 15013 Denver West Parkway \\ Golden, CO 80401 \\ NREL Contract No. DE-AC36-08GO28308 \\ Prepared by: \\ K. Ueno \\ Building Science Corporation \\ 3 Lan Drive, Suite 102 \\ Westford, MA 01886 \\ NREL Technical Monitor: Stacey Rothgeb \\ Prepared under Subcontract No. KNDJ-0-40337-05
}

March 2015 
The work presented in this report does not represent performance of any product relative to regulated minimum efficiency requirements.

The laboratory and/or field sites used for this work are not certified rating test facilities. The conditions and methods under which products were characterized for this work differ from standard rating conditions, as described.

Because the methods and conditions differ, the reported results are not comparable to rated product performance and should only be used to estimate performance under the measured conditions. 


\section{Contents}

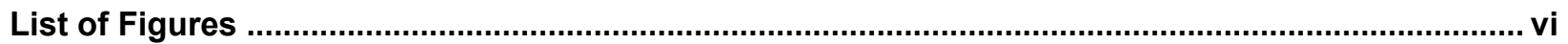

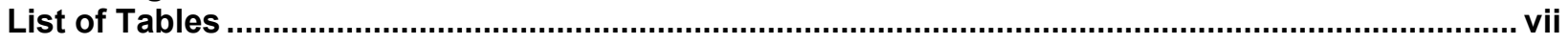

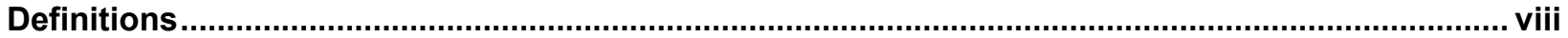

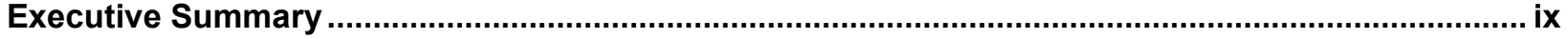

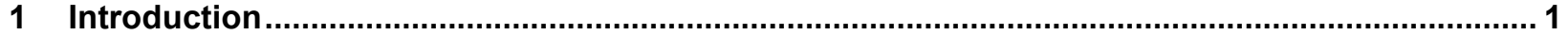

1.1 Transformations Enclosure and Mechanical Characteristics ................................................. 1

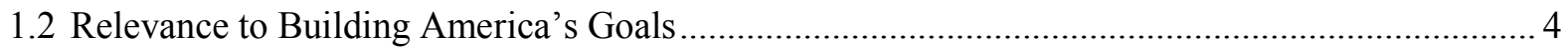

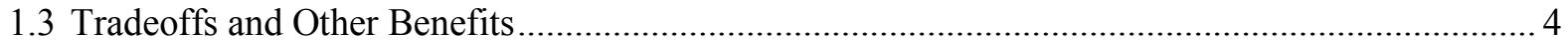

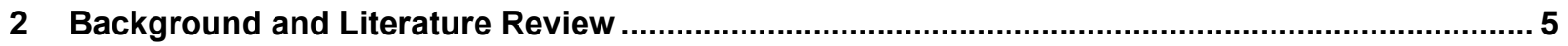

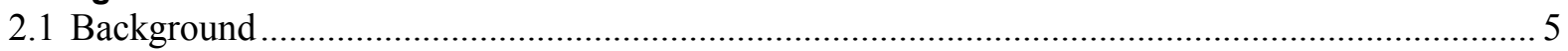

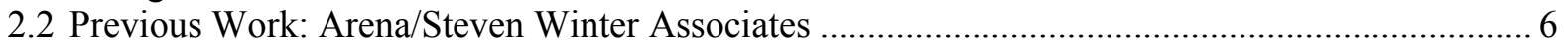

2.3 Previous Work: Ryerson University/University of Waterloo ..................................................... 7

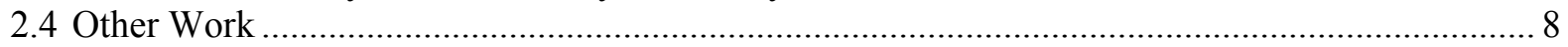

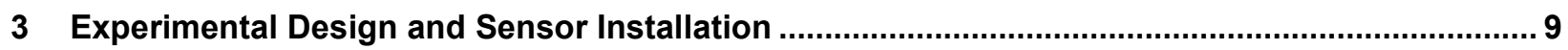

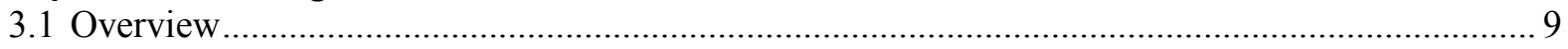

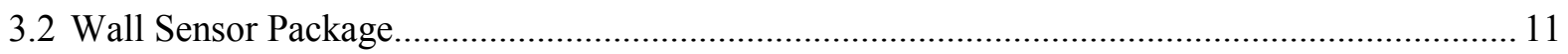

3.3 Additional Sensors and Data Collection Logistics .............................................................. 15

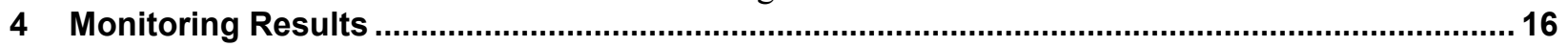

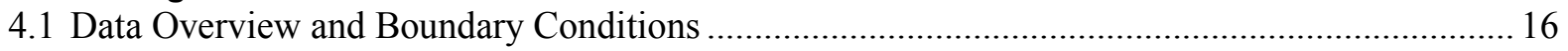

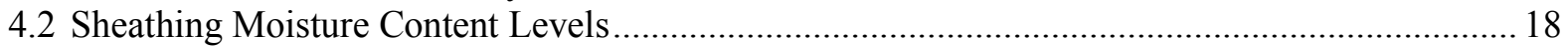

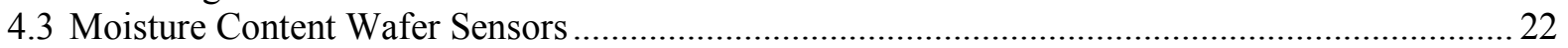

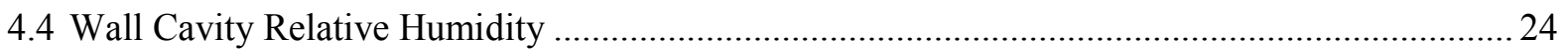

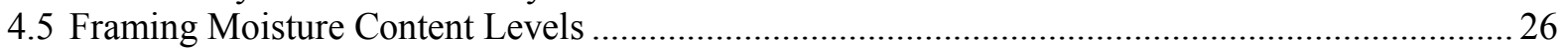

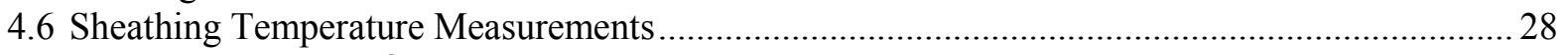

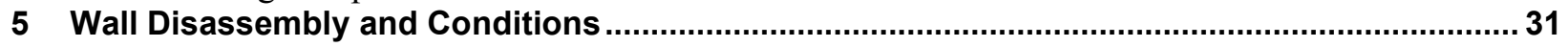

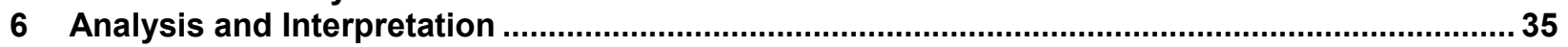

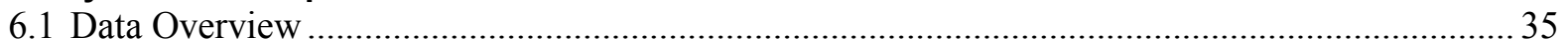

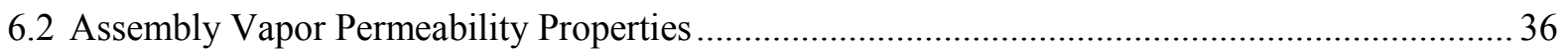

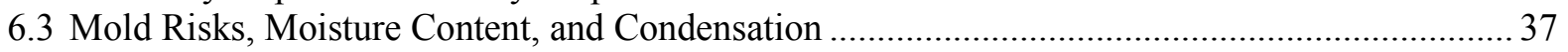

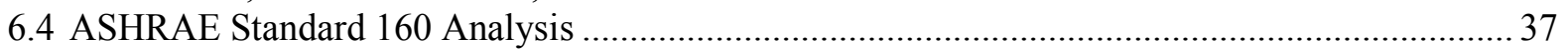

6.5 Temperature-Relative Humidity Plot (Isopleth) Analysis .................................................... 41

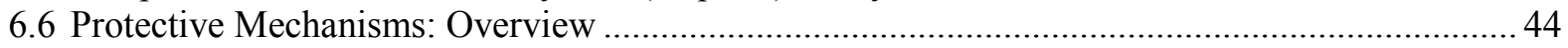

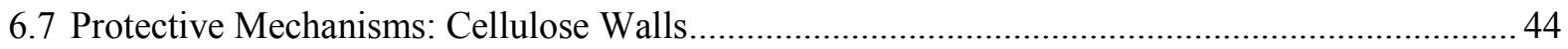

6.8 Protective Mechanisms: Open-Cell Spray Polyurethane Foam Walls ........................................ 46

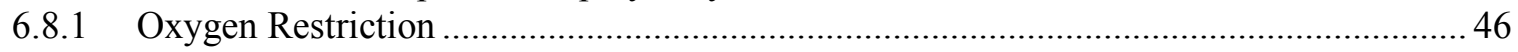

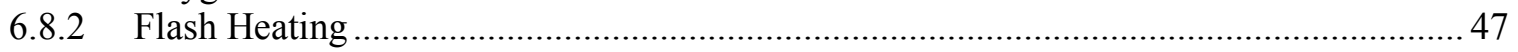

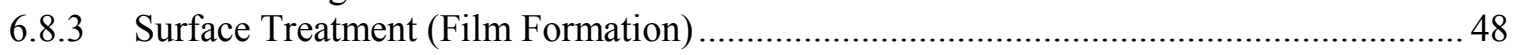

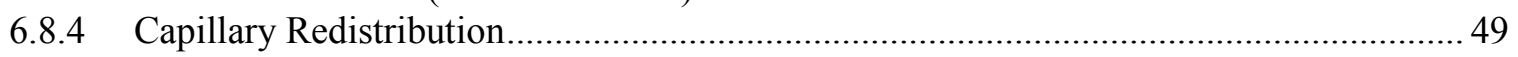

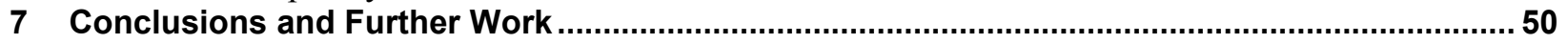

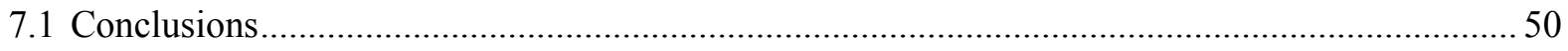

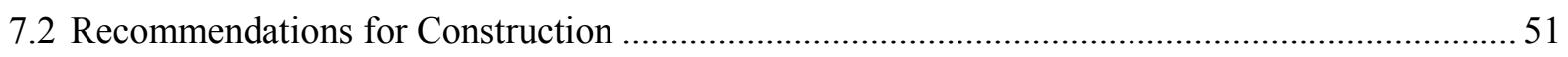

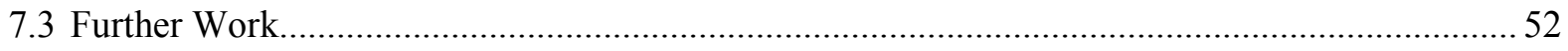

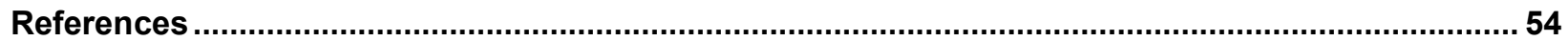




\section{List of Figures}

Figure 1. Transformations enclosure overview section ............................................................... 3

Figure 2. Typical installation of $0.5 \mathrm{lb} / \mathrm{ft}^{3}$ (PCF) ocSPF in double-stud walls .................................... 4

Figure 3. THERM results for double-stud walls; condensing plane highlighted in gray.................... 5

Figure 4. THERM results for 4-in. exterior foam wall; condensing plane highlighted in gray ........... 6

Figure 5. Relative mold risks during air injection (top) and drying (bottom) periods ........................ 8

Figure 6. Overhead $(L)$ and front $(R)$ views of Lot 3 test house ..................................................... 10

Figure 7. Test walls shown on second-floor plan, with guard bay insulation for separation........... 10

Figure 8. Test wall locations shown on exterior of house; south $(L)$ and north $(R)$ orientations..... 11

Figure 9. (L) Temperature and MC sensor at sheathing; (R) sensors at mid-height of stud bay ..... 12

Figure 10. (L) Wafer surrogate RH sensor; $(R)$ schematic of sensor, with dimensions $(\mathrm{mm})$.......... 13

Figure 11. South test walls after installation of sensors, showing double-stud layout ................... 13

Figure 12. Instrumentation diagram for (L) 12-in. OcSPF; (C) 12-in. cellulose; and

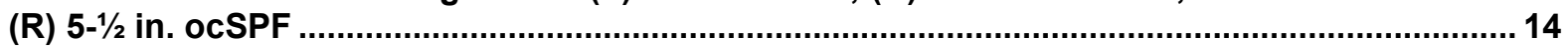

Figure 13. Sensor measure interior (bedroom) T/RH sensors .................................................... 15

Figure 14. (L) Exterior T/RH sensor; (R) data collection from exterior connection port .................. 15

Figure 15. Exterior and interior (test rooms and basement) temperatures ....................................... 16

Figure 16. HDD $\left(65^{\circ} \mathrm{F}\right)$ for Fitchburg, Massachusetts airport (KFIT) ............................................. 17

Figure 17. Interior RHs (test rooms and basement); ventilation operation shown ......................... 17

Figure 18. Exterior and interior (test rooms and basement) dew point temperatures ...................... 18

Figure 19. Sheathing MC/temperature sensor locations (bottom shown in picture) ....................... 19

Figure 20. North side sheathing MCs, with exterior temperature for reference ................................ 20

Figure 21. South side sheathing MCs, with exterior temperature for reference ............................ 21

Figure 22. Sheathing-insulation interface wafer sensor location ................................................. 22

Figure 23. North side wafer sensor MCs, with exterior temperature for reference ............................22

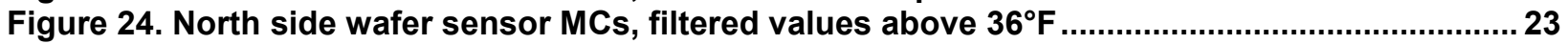

Figure 25. South side wafer sensor MCs, with exterior temperature for reference .......................... 24

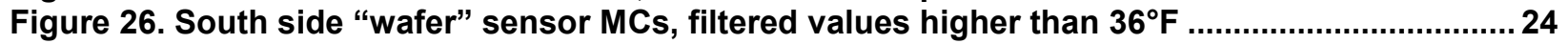

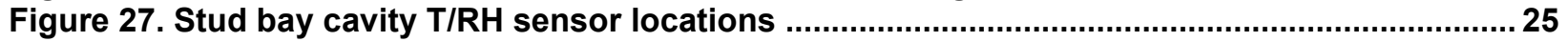

Figure 28. North-facing wall exterior side RH, with exterior temperature for reference ................... 25

Figure 29. North-facing wall interior side RH, with interior RH and exterior temperature for

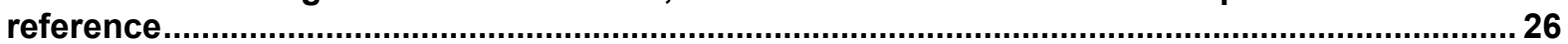

Figure 30. Framing MC/temperature sensor locations................................................................. 26

Figure 31. North-facing wall exterior framing MC, with exterior temperature for reference ..............27

Figure 32. South-facing wall exterior framing MCs, with exterior temperature for reference ...........27

Figure 33. North-facing wall interior framing MCs, with exterior temperature for reference ............. 27

Figure 34. South-facing wall exterior framing MCs, with exterior temperature for reference .......... 28

Figure 35. South-facing wall infrared image; $50^{\circ} \mathrm{F}\left(10^{\circ} \mathrm{C}\right)$ outdoor conditions ................................. 28

Figure 36. North-facing wall sheathing temperatures, mid-height (December-January) .................29

Figure 37. North-facing wall sheathing temperatures, mid-height (January 2 weeks) ..................... 29

Figure 38. Sheathing temperature versus outdoor temperature, middle and upper north

sheathing.

Figure 39. South-facing wall disassembly, showing test bay cavities ......................................... 31

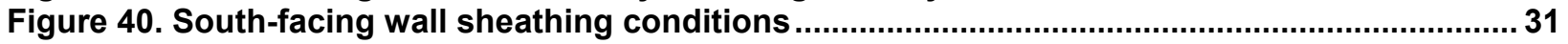

Figure 41. Sheathing and framing conditions at south-facing walls ........................................... 32

Figure 42. North-facing wall disassembly, showing test bay cavities .......................................... 32

Figure 43. South-facing wall sheathing conditions (12-in. ocSPF/N1 and cellulose/N2) .................. 33

Figure 44. North-facing wall conditions at fastener and sheathing at cellulose bay (N2)................ 33

Figure 45. Stud bay cavity and sheathing conditions at 5-1/2-in. ocSPF north-facing wall (N3)........ 34

Figure 46. ASHRAE Standard 160 evaluation of north-facing walls, insulation-sheathing interface

Figure 47. ASHRAE Standard 160 evaluation of south-facing walls, insulation-sheathing interface

Figure 48. 30-day running average surface $\mathrm{RH}$, north walls 
Figure 49. Hourly surface RH, north walls, with ASHRAE 160 failure hours 40

Figure 50. T/RH conditions for mold growth

Figure 51. Isopleth example, with Viitanen, ASHRAE 160, and LIM $_{\text {Bau }}$ criteria plotted

Figure 52. North-facing walls, winter 2012-2013 (November-May) T/RH plots, insulationsheathing interface.

Figure 53. South-facing walls, winter 2012-2013 (November-May) T/RH plots, insulation-

sheathing interface.

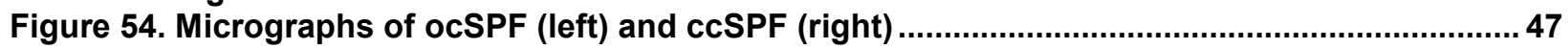

Figure 55. Infrared images of ccSPF application on a mass masonry substrate.............................. 48

Figure 56. Bulk water leakage through ocSPF, visible at interior...................................................... 49

Unless otherwise noted, all figures were created by Building Science Corporation.

\section{List of Tables}

Table 1. Transformations, Inc. Typical Enclosure and Mechanical Specifications............................ 2

Table 2. Test Wall Listing for Fox (2014), With Cavity Depth and Nominal R-Value ........................... 7

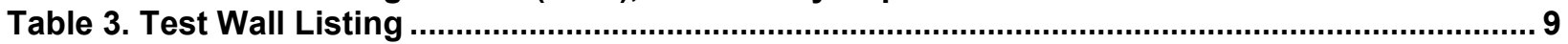

Table 4. Peak Wintertime MCs for Sheathing, Wafer and Outer Framing (Three Winters) .................. 35

Table 5. Vapor Permeability of Insulation and Assemblies ................................................................. 36

Table 6. Hours and Percent of Monitored Period Failing ASHRAE 160 Criteria ................................. 39

Table 7. Sterilization Temperatures Required for Various Mold Species ........................................ 48

Unless otherwise noted, all tables were created by Building Science Corporation. 


\section{Definitions}

ASHRAE American Society of Heating, Refrigerating and Air-Conditioning Engineers, Inc.

ACH 50 Air changes per hour at 50 Pascal test pressure

ccSPF Closed-cell spray polyurethane foam

CFM Cubic feet per minute

DOE U.S. Department of Energy

FPL USDA Forest Products Laboratory

HDD Heating degree day

ICC International Code Council

LIM Lowest isopleth for mold

MC Moisture content

MDI Methylene diphenyl diisocyanate

NYSERDA New York State Energy Research and Development Authority

ocSPF Open-cell spray polyurethane foam

OSB Oriented strand board

PCF Pounds per cubic foot

RH Relative humidity

RSI R-value SI $\left(\mathrm{K} \cdot \mathrm{m}^{2} / \mathrm{W}\right)$

T/RH Temperature/relative humidity

WUFI Wärme and Feuchte Instationär

XPS Extruded polystyrene 


\section{Executive Summary}

Double-stud walls insulated with cellulose or low-density spray foam can have R-values of 40 or higher. They have been used in high performance housing since the 1970s; their advantages include trade familiarity with construction detailing (especially at the exterior), and the use of commonly available construction materials. However, double-stud walls have a higher risk of interior-sourced condensation moisture damage compared to high-R approaches using exterior insulating sheathing.

The U.S. Department of Energy Building America team, Building Science Corporation, monitored moisture conditions in double-stud walls from 2011 through 2014 at a new production house located in Devens, Massachusetts (U.S. Department of Energy zone 5A). The builder, Transformations, Inc., has been using double-stud walls insulated with 12 in. of open cell polyurethane spray foam (ocSPF); however, the company has been considering a change to netted and blown cellulose insulation for cost reasons. Cellulose is a common choice for doublestud walls because of its lower cost (in most markets). However, cellulose is an air-permeable insulation, unlike spray foams, raising interior moisture risks.

Three double-stud assemblies were compared: 12 -in. ocSPF, 12 -in. cellulose, and 5-1/2-in. ocSPF at the exterior of a double-stud wall (to approximate conventional $2 \times 6$ wall construction and insulation levels, acting as a control wall). These assemblies were repeated on the north and south orientations, for a total of six assemblies.

Data were collected from December 2011 through July 2014, capturing three winters of operation in various states. Winter 2011-2012 was very mild (warm) and the house had very low interior relative humidity (RH) because it was unoccupied. Winter 2012-2013 was colder and the house had very high $(40 \%-50 \%)$ interior $\mathrm{RH}$ until the ventilation system was put into operation (mid-February 2013). Winter 2013-2014 was very cold, but the ventilation system was operated, resulting in moderate interior RHs.

Under "normal" interior conditions (functioning ventilation system, wintertime RH 10\%-30\%), ocSPF walls (both 12 in. and 5-1/2 in.) with latex paint as interior vapor control (nominally Class III, but possibly more vapor open) showed low risk; all sheathing moisture contents (MCs) remained lower than 20\%. However, the 12-in. cellulose wall had MCs higher than $20 \%$ on the north side. In addition, the cellulose wall sheathing-insulation interface had high RH conditions.

Under high interior humidity loading (nonfunctional ventilation system, $40 \%-50 \%$ interior $\mathrm{RH}$ ), all test walls showed MCs and sheathing-insulation interface RHs well into the high risk range. The cellulose walls showed particularly high MCs (sheathing in excess of 30\%), while the ocSPF walls showed MCs in the $18 \%-25 \%$ range. In addition, the monitoring showed evidence of liquid water condensation (which can result in quick degradation) in all walls; the condensation was substantial in the cellulose walls. These condensation issues occurred on the north and south sides.

But in all walls, during each summer after a winter of wetting, moisture levels fell well into the safe range. Based on the difference between the winters, it is clear that interior RH can have a 
tremendous effect on the performance of enclosure systems, in terms of interstitial condensation risks, when using more vapor-open interior finishes such as latex paint.

The ocSPF walls showed consistently lower MCs and interface RH levels than the cellulose walls. Although air leakage cannot be eliminated as a possibility, it is likely that at the thicknesses applied, the ocSPF provided reasonable vapor control (1.5-3.5 perms when combined with Class III latex paint) under normal loading conditions.

The collected data were analyzed in terms of ASHRAE Standard 160 criteria (tabulating hours with RH and temperatures that support mold growth), using the calculated surface $\mathrm{RH}$ at the sheathing-insulation interface. All north-facing walls failed through all three winters; in particular, there were large numbers of failure hours during the high humidity winter (20122013). Sheathing-insulation interface temperatures and RHs during the high humidity winter showed many hours with mold risk conditions (high humidity and sufficient temperature for mold growth).

When the walls were disassembled at the conclusion of the experiment, the sheathing and framing showed remarkably little evidence of wetting damage or mold growth. No visible mold growth or evidence of staining or water rundown was found. The damage was limited to some limited grain raise of the interior surface of the oriented strand board at the cellulose wall, and slight corrosion of fasteners and staples.

Based on the data, calculations, and analysis, all three walls should be at high risk of failure; the analytic tools used indicate that these walls should have failed. However, disassembly showed that the walls were essentially undamaged by the monitored moisture exposure. This suggests that the walls, at least in the configurations tested, were far more robust than current analysis tools would indicate. Various theories were proposed on what protective mechanisms might be at work in these assemblies, in particular, the effect of cavity fill insulation.

The cellulose walls were likely protected by borate preservatives (which inhibit mold) and the ability to safely store moisture. However, the literature shows that, although borate-treated cellulose can have significant mold-inhibiting effects, it is not a panacea; if the moisture loading is sufficiently high, mold will grow.

The protective mechanism of the ocSPF wall was not clear; proposed theories included restriction of oxygen to the sheathing-insulation interface, flash heating of the surface during spray foam application (thus sterilizing the interface), coating of the substrate surface with a polyurethane film (thus rendering the wood inaccessible to mold), and capillary redistribution of moisture. Based on resources in the literature, the oxygen theory seems unlikely, given the low oxygen requirements of mold. Similarly, the flash heating theory seems unlikely: the time required to sterilize samples is longer than would occur during installation. Surface treatment and capillary redistribution seem to be plausible, albeit unconfirmed, explanations.

In terms of construction recommendations, a Class II vapor retarder (e.g., variable permeability membrane or vapor retarder paint) will reduce moisture risks in the cellulose walls to more reasonable levels. But it is entirely likely that many double-stud walls are insulated with cellulose with only Class III vapor control and provide fine service. It is a marginal judgment 
call whether a Class II vapor retarder is needed or warranted in ocSPF walls. In either case, a Class I vapor retarder (polyethylene) is not recommended, because it completely eliminates inward drying. 


\section{Introduction}

Double-stud walls insulated with cellulose or low-density spray foam can have R-values of 40 or higher. They have been used in high performance housing since the 1970s; their advantages include trade familiarity with construction detailing (especially at the exterior) and the use of commonly available construction materials. However, double-stud walls have a higher risk of interior-sourced condensation moisture damage compared to high-R approaches using exterior insulating sheathing. Insulation outboard of structural sheathing increases (warms) the winter temperature of the sheathing, while additional insulation inboard of the sheathing decreases its temperature (Straube and Smegal 2009).

The U.S. Department of Energy Building America team, Building Science Corporation, monitored moisture conditions in double-stud walls from 2011 through 2014 at a new production house located in Devens, Massachusetts (U.S. Department of Energy [DOE] zone 5A, per ICC 2009). The builder, Transformations, Inc., has been using double-stud walls insulated with 12 in. of open-cell polyurethane spray foam (ocSPF); however, the company has been considering a change to netted and blown cellulose insulation for cost reasons. Cellulose is a common choice for double-stud walls because of its lower cost (in most markets). However, cellulose is an airpermeable insulation, unlike spray foams, raising interior moisture risks.

Three double-stud assemblies were compared: $12 \mathrm{in.} \mathrm{of} \mathrm{ocSPF,} 12 \mathrm{in}$. of cellulose, and 5-1/2 in. of ocSPF at the exterior of a double-stud wall (to approximate conventional $2 \times 6$ wall construction and insulation levels, acting as a control wall). These assemblies were repeated on the north and south orientations, for a total of six assemblies. Sensors within the wall measured wood moisture contents (MCs) (of sheathing and framing), temperature (T), and relative humidity $(\mathrm{RH})$. Interior and exterior boundary conditions $(\mathrm{T} / \mathrm{RH})$ were also monitored.

\subsection{Transformations Enclosure and Mechanical Characteristics}

Transformations, Inc. is a residential development and building company with a proven track record of delivering high performance super-insulated housing at a cost-effective price point in a variety of Massachusetts markets (DOE zone 5A). These houses have been covered in previous work, including Bergey and Ueno (2011), Ireton (2013), and Ueno et al. (2013). For reference, the basic enclosure and mechanical specifications for their work are shown in Table 1. 
Table 1. Transformations, Inc. Typical Enclosure and Mechanical Specifications

\begin{tabular}{|c|c|}
\hline Item & Description \\
\hline Full Basement & $\begin{array}{l}\text { 2-in. extruded polystyrene (XPS) rigid insulation (R-10) under slab } \\
3-1 / 2 \text {-in. closed cell spray foam (ccSPF) insulation }(\mathrm{R}-20) \text { at basement walls }\end{array}$ \\
\hline Slab on Grade & $\begin{array}{l}\text { 6-in. XPS rigid insulation }(\mathrm{R}-30) \text { under the slab and } \\
\text { 4-in. XPS rigid insulation }(\mathrm{R}-20) \text { at the edge of the slab }\end{array}$ \\
\hline $\begin{array}{l}\text { Above-Grade } \\
\text { Walls }\end{array}$ & $\begin{array}{l}\text { Double-stud wall with } 12 \text {-in. ocSPF ( } 0.5 \text { per cubic foot }[\mathrm{PCF}]) \text { insulation } \\
\text { (R-46 nominal) }\end{array}$ \\
\hline Attic & Ventilated attic; 18 -in. cellulose insulation (R-63) \\
\hline Windows & $\begin{array}{l}\text { Vinyl-frame, double-hung, triple-glazed, } \mathrm{U}=0.22 \text {, solar heat gain } \\
\text { coefficient }=0.17 \text { typical }\end{array}$ \\
\hline Airtightness & $1.0-1.5$ ACH50 range, typical \\
\hline Heating/Cooling & $\begin{array}{l}\text { Two Mitsubishi FE12NA (MUZ-FE12NA + MSZ-FE12NA) } \\
\text { ductless heat pumps; one per floor, typical }\end{array}$ \\
\hline $\begin{array}{l}\text { Domestic Hot } \\
\text { Water }\end{array}$ & $\begin{array}{c}\text { Navien tankless instantaneous water heater, NR-180, } \\
\text { in basement or conditioned space }\end{array}$ \\
\hline Ventilation & $\begin{array}{c}\text { Panasonic } 30 \text { CFM exhaust-only fan, continuous operation with boost } \\
\text { option, two fans (baseline system; varies in some houses) }\end{array}$ \\
\hline
\end{tabular}

A typical Transformations enclosure cross section is illustrated in Figure 1. 

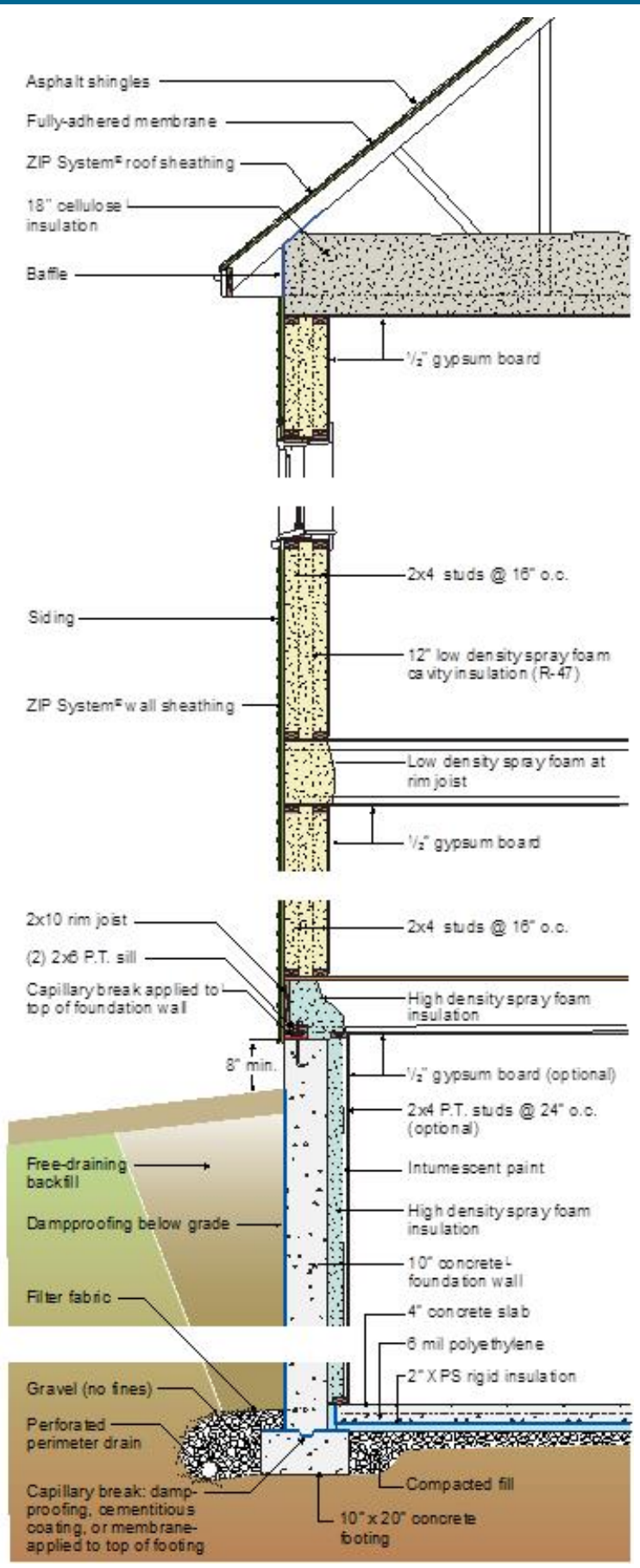

Figure 1. Transformations enclosure overview section

Part of Transformations Inc.'s strategy of producing high performance homes without a significant cost increase is to offset the cost of upgrading the building enclosure/shell by reducing the size and cost of the mechanical systems. Double-stud walls with ocSPF have been standard components of Transformation's production-level high performance houses (Figure 2). 

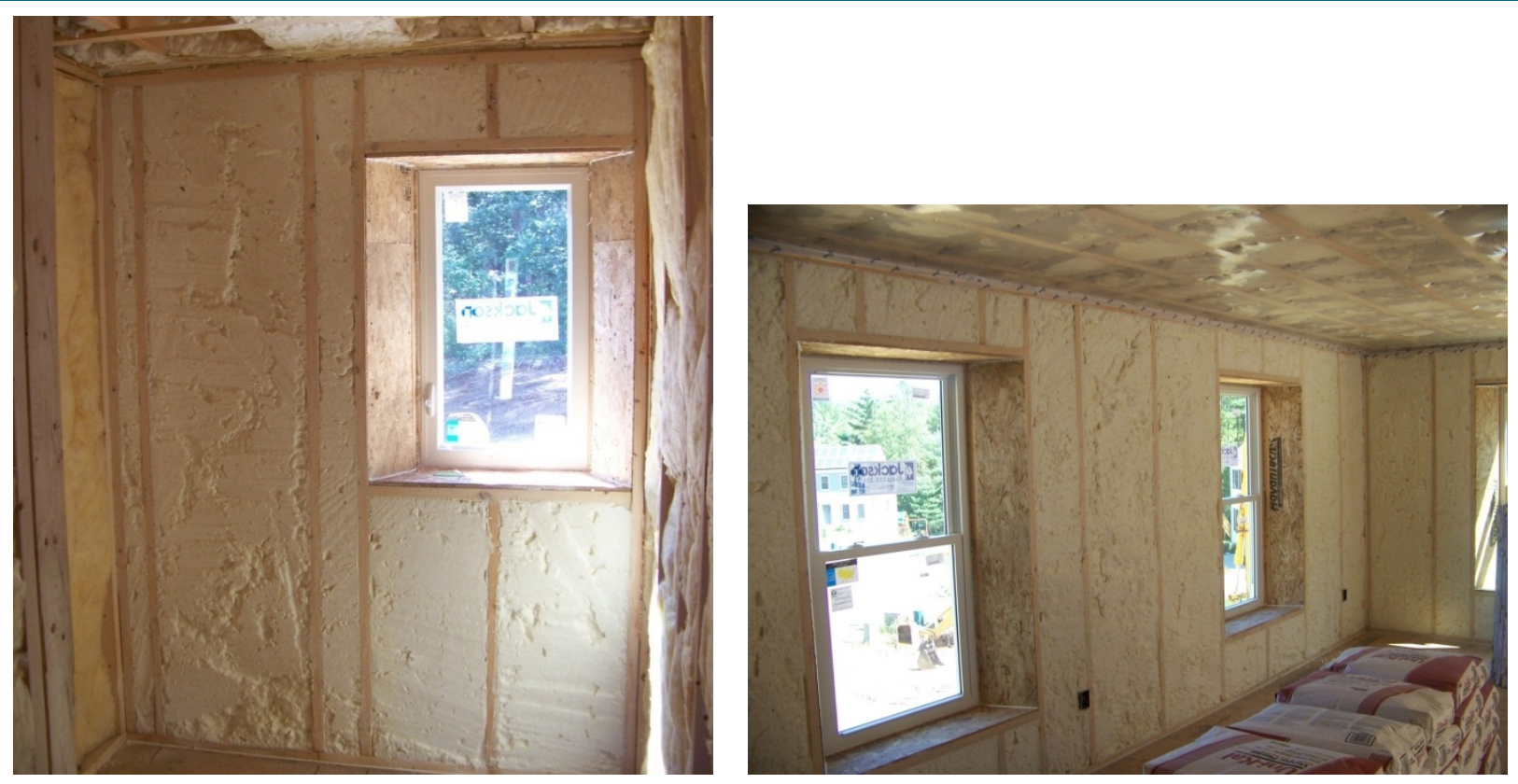

Figure 2. Typical installation of $0.5 \mathrm{lb} / \mathrm{ft}^{3}(\mathrm{PCF})$ ocSPF in double-stud walls

\subsection{Relevance to Building America's Goals}

Given the Building America goals of reducing home energy use by 30\%-50\% (compared to 2009 energy codes for new homes and pre-retrofit energy use for existing homes), double-stud walls are a commonly considered option for high R-value walls. Greater understanding of the moisture risks associated with these walls (and exploring potential solutions) opens up options for builders of high performance houses.

\subsection{Tradeoffs and Other Benefits}

The common concern for double-stud walls is the potential durability risks associated with this wall assembly. Reduction of heat flow through an assembly results in reduced drying; therefore, higher R assemblies are more vulnerable to moisture-related damage (Lstiburek 2008). Energy conservation and durability are both cornerstones of sustainable design. Emphasizing one attribute while sacrificing the other is a poor tradeoff; the two must be balanced against each other. 


\section{Background and Literature Review}

\subsection{Background}

Double-stud walls insulated with cellulose or low-density spray foam can have R-values of 40 or higher. They have been used in high performance housing since the 1970s; their advantages include trade familiarity with construction detailing (especially at the exterior), elimination of thermal bridging in the field of the wall (albeit not at window openings or floor framing), and the use of commonly available construction materials (Coldham 2010; Wagner 2012).

However, double-stud walls have a higher risk of interior-sourced condensation moisture damage compared to approaches using exterior insulating sheathing. Insulation outboard of structural sheathing increases (warms) the winter temperature of the sheathing, while additional insulation inboard of the sheathing decreases its temperature (Straube and Smegal 2009).

This is demonstrated in the thermal simulation results shown in Figure 3 and Figure 4, which compare temperatures for a double-stud wall with a 4-in. exterior foam wall, assuming an interior temperature of $68^{\circ} \mathrm{F}$ and an exterior temperature of $-4^{\circ} \mathrm{F}$. The surface that is the most likely to experience condensation (interior side of exterior sheathing) is highlighted in each wall in gray, showing the relative risks of air leakage or vapor diffusion-based condensation.

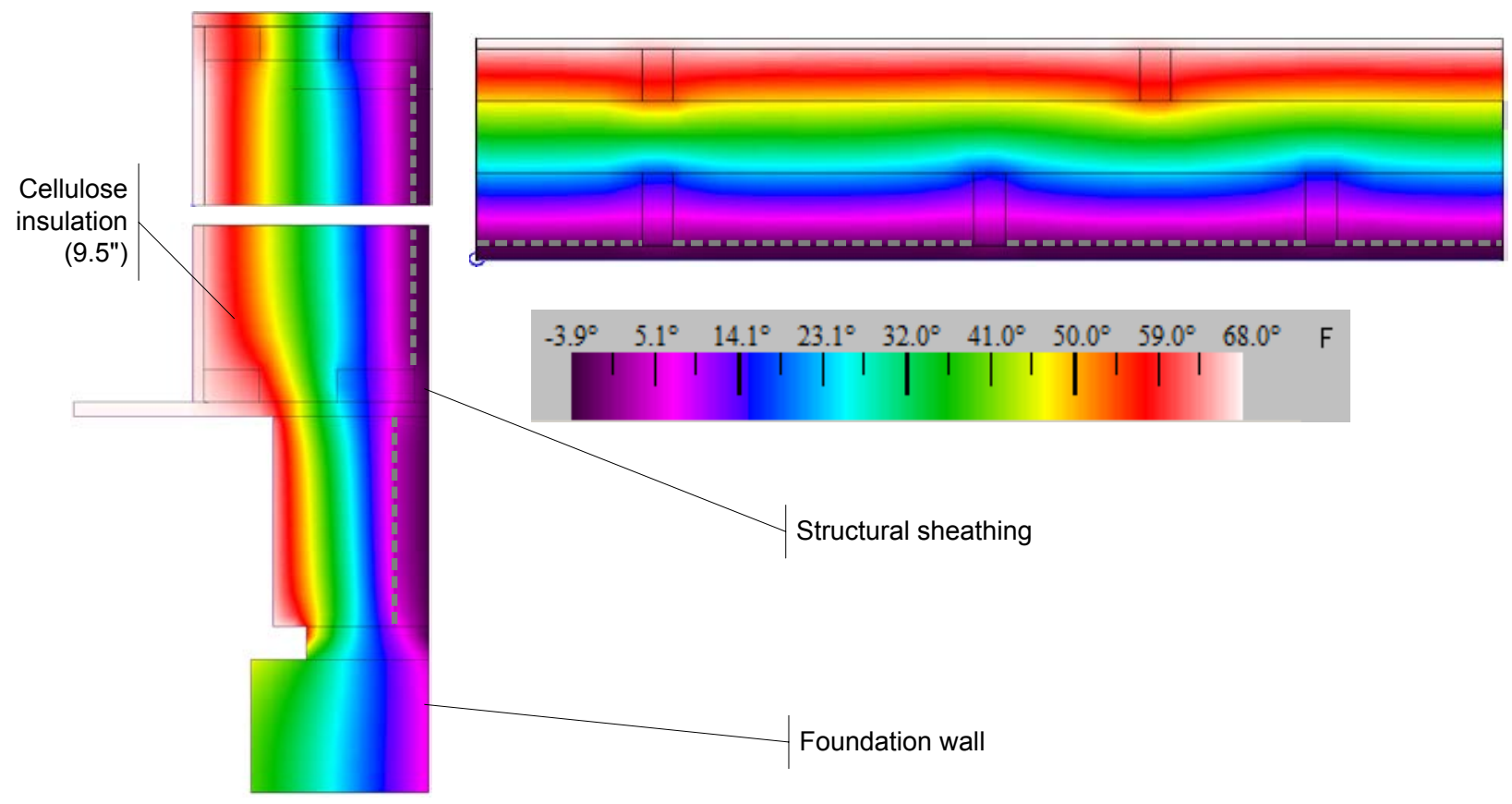

Figure 3. THERM results for double-stud walls; condensing plane highlighted in gray (based on Straube and Smegal 2009) 


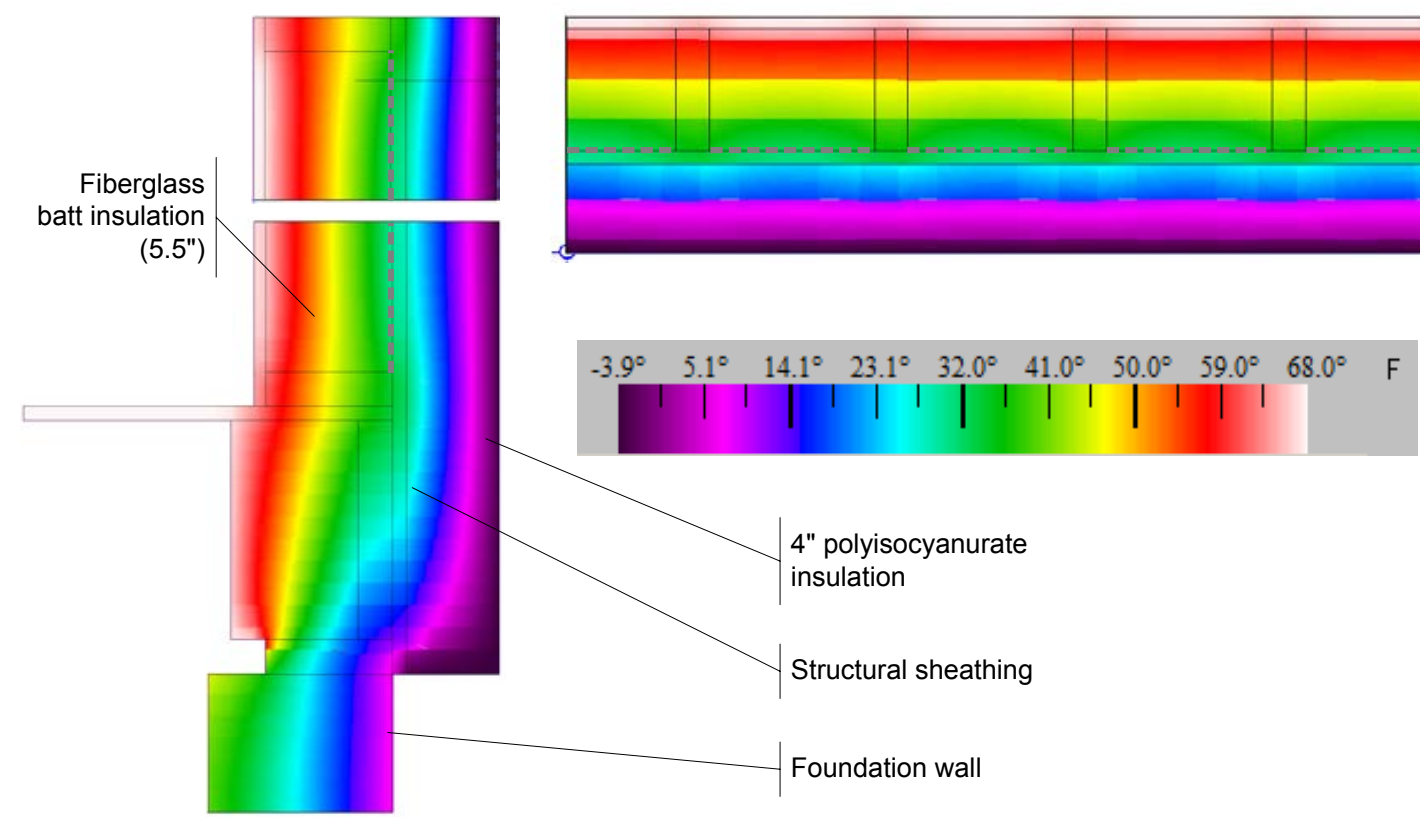

Figure 4. THERM results for 4-in. exterior foam wall; condensing plane highlighted in gray

(based on Straube and Smegal 2009)

If a double-stud wall is compared to a $2 \times 6$ wall with the same type of stud bay insulation and no exterior insulating sheathing, the double-stud wall sheathing experiences colder wintertime temperatures and less heat flow. Both of these factors increase the risks of moisture-related problems (Lstiburek 2008; LePage et al. 2013).

Low-density spray foam (ocSPF, $0.5 \mathrm{lb} / \mathrm{ft}^{3}$ or $8 \mathrm{~kg} / \mathrm{m}^{3}$ ), with a similar R-value to cellulose, is believed to have lower moisture risk because its superior control of air leakage reduces the risk of wetting the exterior sheathing by interior-sourced moisture. However, the insulation material is still open to vapor diffusion: a 12-in. (305-mm) thickness of ocSPF has a vapor permeability of $7.3 \mathrm{perms} / 419 \mathrm{ng} /\left(\mathrm{Pa} \cdot \mathrm{s} \cdot \mathrm{m}^{2}\right)$ (both wet and dry cup; ASHRAE 2009a), while $12 \mathrm{in}$. of cellulose is roughly 7-10 perms/402-575 $\mathrm{ng} /\left(\mathrm{Pa} \cdot \mathrm{s} \cdot \mathrm{m}^{2}\right)$ (dry and wet cup).

\subsection{Previous Work: Arena/Steven Winter Associates}

Arena et al. (2013) monitored MCs in double-stud walls insulated with cellulose in DOE zone 5A (Devens, Massachusetts). Walls were monitored for temperature, RH, and MC on the north and south sides. The wall thickness was 10-1/2 in. (267 mm), resulting in nominal R-40 (RSI 7.0) insulation. A vapor retarder primer (Class II) was applied to the interior gypsum board.

South side sheathing MCs peaked near 17\%, while north side MCs peaked at slightly higher than $20 \%$. Wintertime interior RH levels were typically in the $20 \%-30 \%$ range, with slightly higher than typical interior temperatures $72^{\circ}-73 \mathrm{~F}\left(22^{\circ}-23^{\circ} \mathrm{C}\right)$.

The assemblies were also simulated using WUFI. Correlation between measurements and simulations were difficult; the model was tuned assuming a bulk water leak at the MC pins, which improved correlation. 
The assemblies were also evaluated in terms of ASHRAE Standard 160 criteria: based on monitored data, both north and south walls fail. However, the authors have simulated other common walls using ASHRAE 160, and have found that many commonly used walls fail this test, which suggests that the standard has overly conservative criteria for failure.

Arena (2014) continued work on monitoring double-stud walls, using New York State Energy Research and Development Authority (NYSERDA) funding to monitor two walls in climate zone 6 (upstate New York). The study compared two double-stud wall designs: a 12-in. cellulose wall and one with $3-1 / 2-i n$. ccSPF at the exterior of the stud cavity; the remainder was filled with 8-1/2-in. cellulose insulation. Sheathing MCs through winter 2013-2014 remained in the safe range (daily averages below 12\%). Monitoring is ongoing, and will be reported on in late 2014.

The researchers found similar problems with ASHRAE 160: most of the walls fail the criteria (both measured data and WUFI simulations), even though monitoring shows low risk based on sheathing MCs.

\subsection{Previous Work: Ryerson University/University of Waterloo}

Fox (2014) monitored multiple high R-value wall assemblies in a test hut in Kitchener-Waterloo, Ontario (climate zone 6A); the test was run from October through June, capturing one fallwinter-spring period. The walls included deep cavity walls insulated with dense-packed cellulose (double-stud and I-joist), cavity walls with exterior insulation (polyisocyanurate, XPS, and mineral wool), a ccSPF wall (with $2 \times 8$ studs), and a "datum" or baseline comparison wall $(2 \times$ 6 with cavity insulation). The walls are described in Table 2 , with cavity depth and nominal Rvalue (which do not account for thermal bridging). The exterior was finished with fiber cement clapboard on a rain screen/drainage space; an interior polyethylene vapor retarder (Class I) was used on all walls except for the exterior insulation walls $(5,6$, and 7$)$.

Table 2. Test Wall Listing for Fox (2014), With Cavity Depth and Nominal R-Value

\begin{tabular}{c|c|c|c}
\hline $\begin{array}{c}\text { Wall } \\
\text { ID }\end{array}$ & Wall Construction & Cavity Depth & $\begin{array}{c}\text { Nominal } \\
\text { R-Value }\end{array}$ \\
\hline N1/S1 & Double stud with dense-packed cellulose & $11-1 / 4$ in. & $\mathrm{R}-39$ \\
N2/S2 & I-joist stud with dense-packed cellulose & $9-1 / 2$ in. & $\mathrm{R}-33$ \\
N3/S3 & $2 \times 6$ datum wall, with fiberglass cavity insulation & $5-1 / 2$ in. & $\mathrm{R}-22$ \\
S4 & $2 \times 8$ closed cell spray foam (ccSPF) & $6-i n$. ccSPF & $\mathrm{R}-36$ \\
N5/S5 & $2 \times 6$ wall with exterior 2-in. polyisocyanurate & $5-1 / 2$ in. & $\mathrm{R}-35$ \\
N6/S6 & $2 \times 6$ wall with exterior 2-1/2-in. extruded polystyrene & $5-1 / 2$ in. & $\mathrm{R}-35$ \\
N7/S7 & $2 \times 6$ wall with exterior 3-in. mineral wool & $5-1 / 2$ in. & $\mathrm{R}-34$ \\
\hline
\end{tabular}

After running the walls for a baseline period (October to mid-February), the walls were stressed in midwinter (mid-February to April) by injecting interior air (at roughly $40 \% \mathrm{RH}$ ) into the insulated stud bay cavities. The airflow rate was set at a constant 40 cubic feet per hour $(0.67$ cubic feet per minute) per panel, which was an attempt to take "typical" modern air leakage levels (2.5 air changes per hour at 50 Pascals) and normalize it over the panel area. The air injection was followed by a drying period (April-June), to examine the walls' recovery from wintertime wetting. 
During the baseline period, all walls had relatively low and stable MCs. However, when interior air leakage was introduced, MCs rose sharply in the walls without exterior insulation, with many MCs exceeding 20\%. North-facing walls had higher MCs than south-facing walls. The number of condensation hours in walls 1 and 2 (double-stud and I-joist) were higher than other walls. For instance, lower wall plate MCs increased to more than 50\% and 35\% in walls N1 and N2, respectively. Walls with exterior insulation, by contrast, showed a slight rise, but were well within the safe range (maximum lower than 15\% MC) because of the warmer temperatures of the condensing surface (interior side of oriented strand board [OSB] sheathing).

These risks were quantified by tabulating the number of hours at mold risk (MC exceeding 16\%, temperature exceeding $41^{\circ} \mathrm{F}\left[5^{\circ} \mathrm{C}\right]$ ), as shown in Figure 5, for the air injection and drying periods. The vertical bars represent various components of the wall (bottom/top plate, OSB sheathing). The deep cavity fill walls (double-stud and I-joist) showed higher risks of mold growth, especially on the north side. In addition, the drying period (when exterior temperatures are warming) was a higher risk condition than the injection period (midwinter).

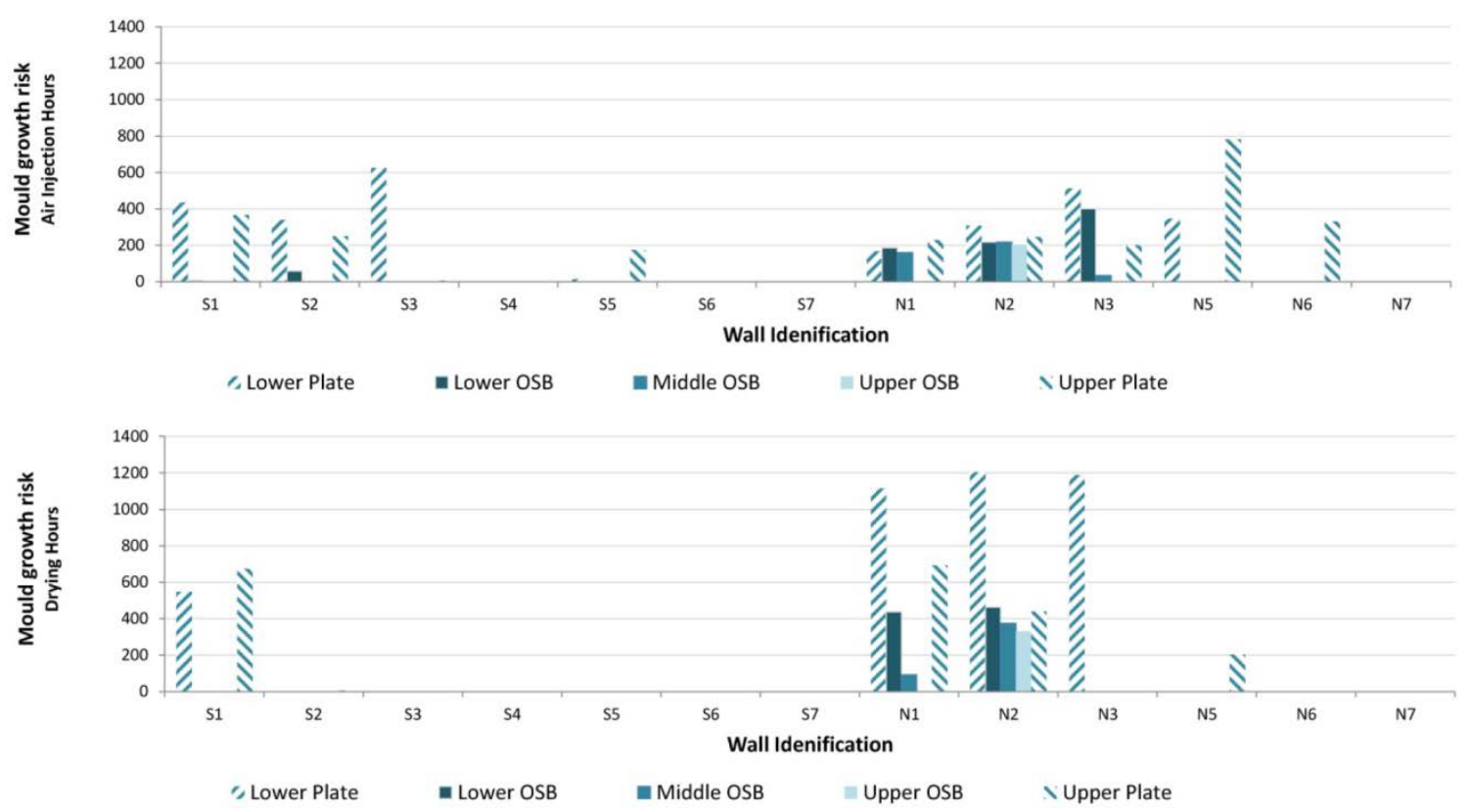

Figure 5. Relative mold risks during air injection (top) and drying (bottom) periods

(Fox 2014)

Overall, this work demonstrated that "thick" walls with cold sheathing (i.e., double-stud and Ijoist walls) are more vulnerable to interior-sourced condensation than exterior insulated walls.

\subsection{Other Work}

Holladay (2013) summarized the research on double-stud walls at that date, including work by Arena, Fox, and preliminary work from this current research in Devens. Cushman (2014) summarized this current research in the popular construction press. 


\section{Experimental Design and Sensor Installation}

\subsection{Overview}

The moisture monitoring field experiment was conducted at a newly constructed house in Devens, Massachusetts. Three wall assemblies were selected for this experiment; they were duplicated on opposite orientations (north and south), for a total of six test wall sections (see Table 3 and Figure 12). Descriptions of the three test insulation materials follow:

- 12-in. 0.5 PCF $\left(1 \mathrm{~b} / \mathrm{ft}^{3}\right)$ ocSPF in a double-stud wall (as per the remainder of the house; typical installation is shown in Figure 2). The spray foam was installed in three passes with time allowed between the passes for cooling.

- 12-in. netted and dry blown-in cellulose in a double-stud wall. The density was not directly measured, but it was reported to be 3.5 PCF. Typical densities achieved for proper dense pack installations behind netting are 3.5-4.0 PCF (Tauer 2012).

Disassembly at the conclusion of the experiment showed good density and no settling.

- $5-1 / 2$-in. 0.5 PCF ocSPF at the exterior of a double-stud wall, to approximate conventional $2 \times 6$ wall construction and insulation levels, acting as a control wall (a.k.a. "shorted" bay).

Table 3. Test Wall Listing

\begin{tabular}{c|c|c|c|c}
\hline $\begin{array}{c}\text { Wall } \\
\text { ID }\end{array}$ & Orientation & Insulation & $\begin{array}{c}\text { Nominal } \\
\text { R-value }\end{array}$ & Notes \\
\hline N1 & North & 0.5 PCF spray foam, 12 in. & 46 & Same as rest of house \\
N2 & North & Netted/blown cellulose, 12 in. & 42 & \\
N3 & North & 0.5 PCF spray foam, 5-1/2 in. & 21 & "Control" \\
S1 & South & 0.5 PCF spray foam, 12 in. & 46 & Same as rest of house \\
S2 & South & Netted/blown cellulose, 12 in. & 42 & "Control" \\
S3 & South & 0.5 PCF spray foam, 5-1/2 in. & 21 & ( \\
\hline
\end{tabular}

The remainder of the wall was constructed as per the builder's conventional construction, with an OSB-based sheathing with an integrated drainage plane and taped seams (no separate house wrap), and vinyl siding. The interior finish is $1 / 2$-in. gypsum board with latex primer and paint finish (Class III vapor retarder).

The control wall (5-1/2-in. 0.5 PCF foam) is mean to represent common construction (a $2 \times 6$ stud frame wall); this assembly has no history or reputation of endemic moisture failures. Data from the control bay (with the same solar and rain exposure as the test walls) were used to interpret the results.

The test home is not oriented directly north-south (Figure 6), but close to northeast and southwest. The southernmost and northernmost exposure walls were used for this research, and are referred to as "north" and "south" for simplicity. 


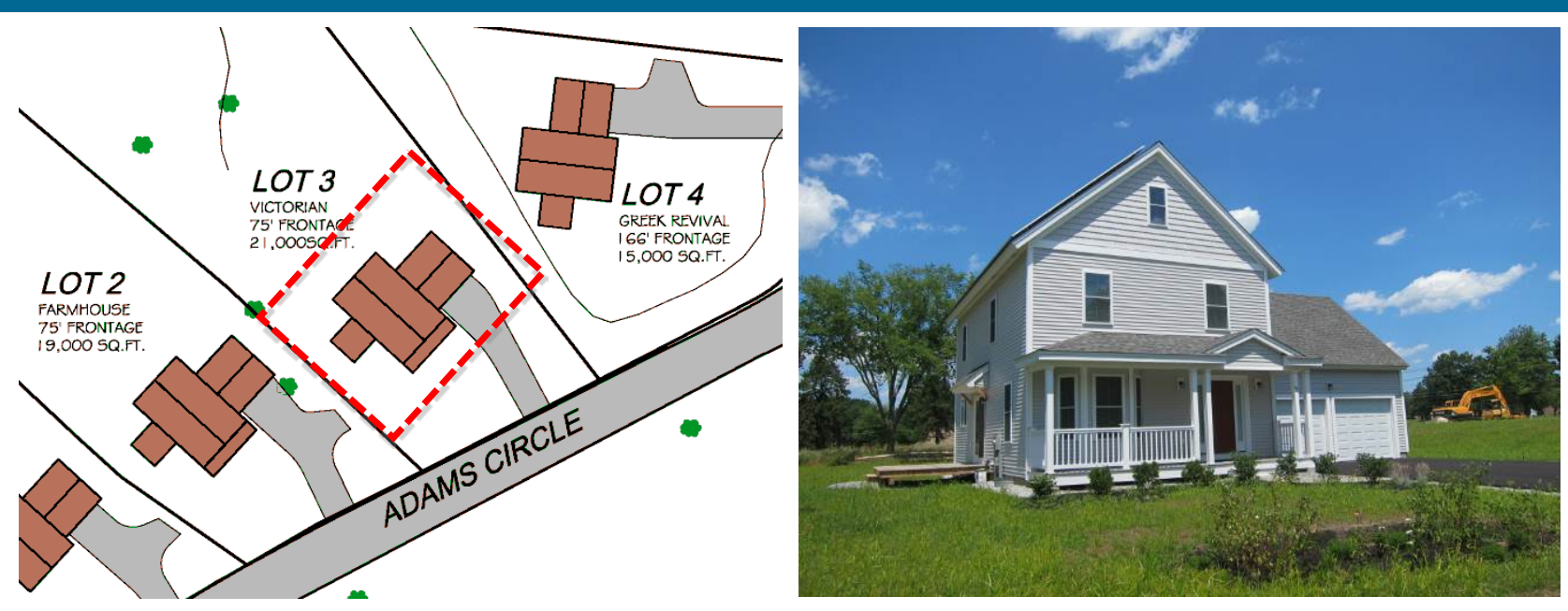

Figure 6. Overhead (L) and front (R) views of Lot 3 test house

The test walls were installed in second-floor bedrooms (Figure 7). The test bays are indicated by the dotted patterns, and the guard areas (noninstrumented portions) are filled with full-thickness spray foam to maintain separation between adjacent bays.

Northernmost-facing walls experience the least solar gain, while southernmost-facing walls receive the most. The two orientations place upper and lower bounds on the moisture problems, because solar gain is the major source of energy to dry the sheathing in highly insulated walls.

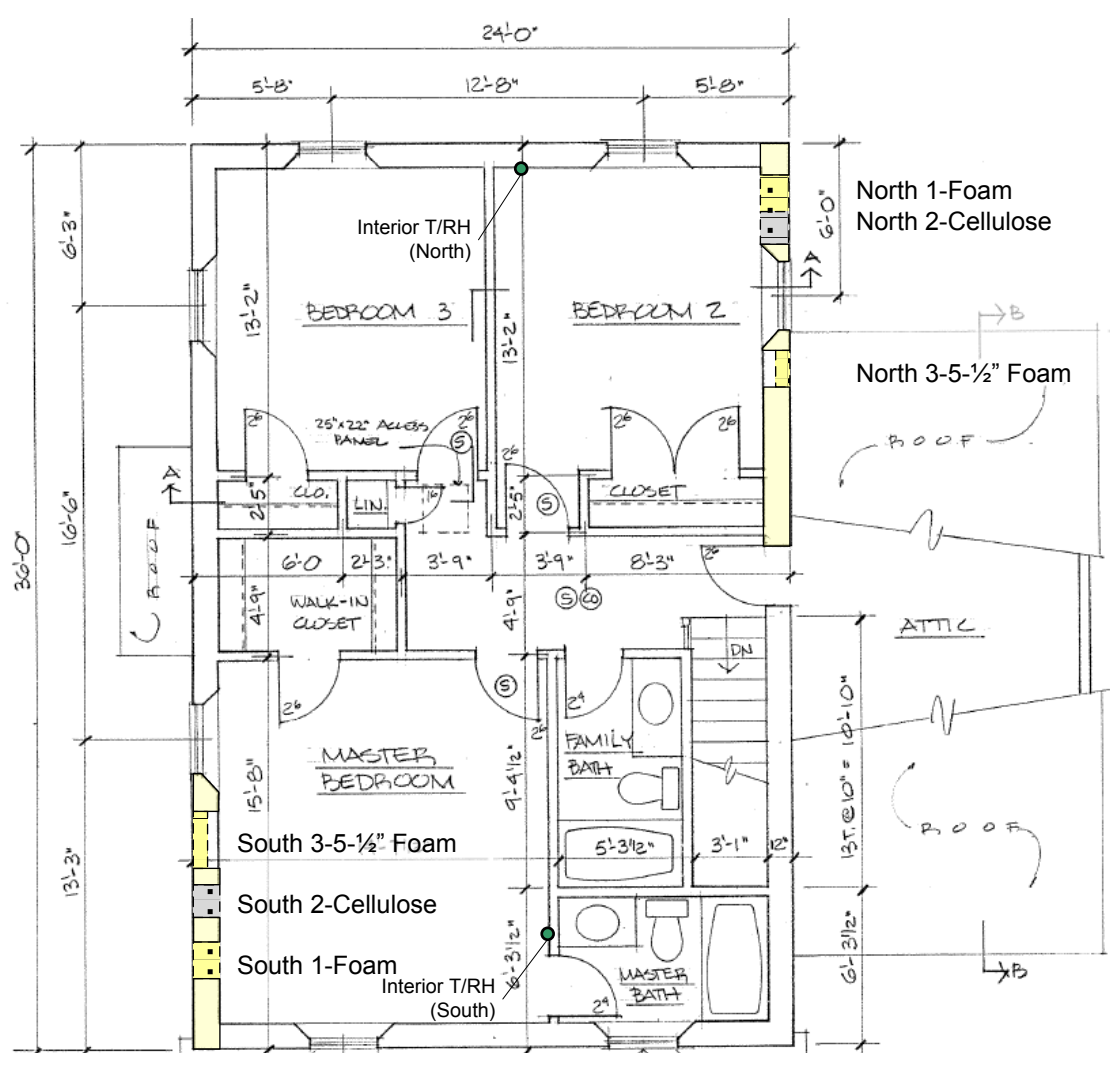

Figure 7. Test walls shown on second-floor plan, with guard bay insulation for separation 
As shown in Figure 8 (right), the third bay ("control") on the north side is partially sheltered at the bottom by the sloping garage roof. No better location was available, because of the positioning of windows, bathrooms, and garage.
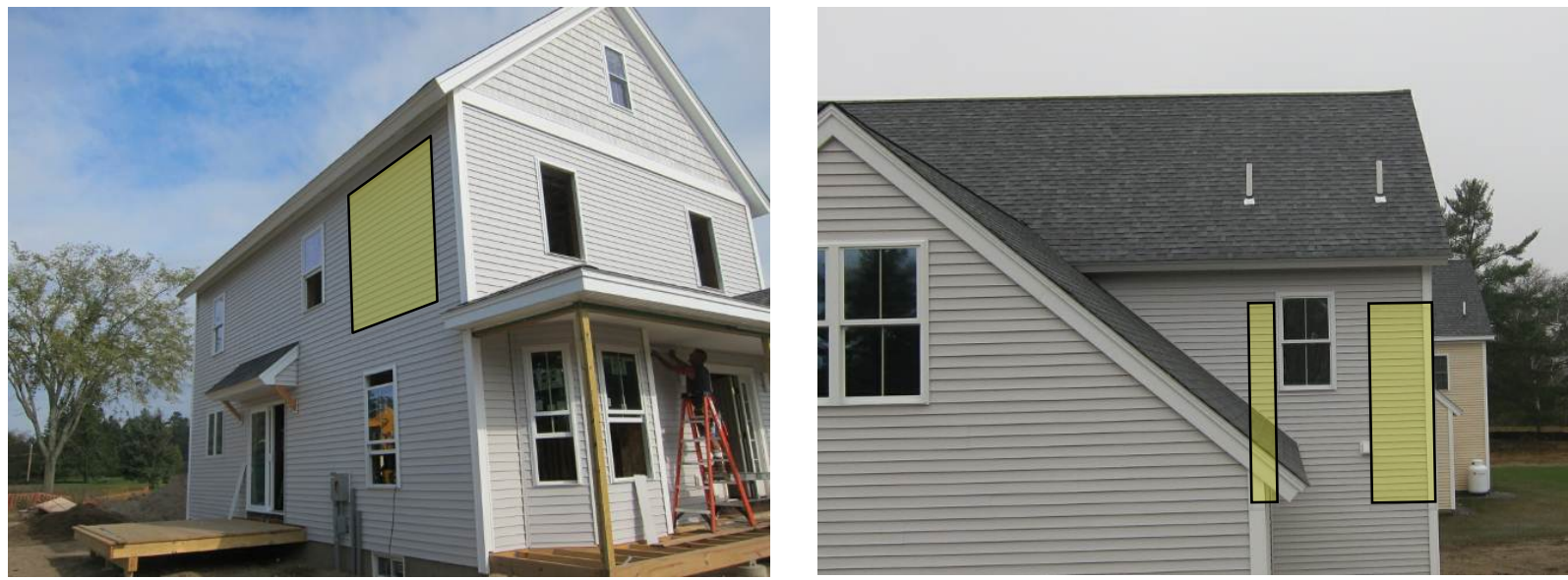

Figure 8. Test wall locations shown on exterior of house; south (L) and north (R) orientations

\subsection{Wall Sensor Package}

Three types of sensors are used to measure conditions within the walls; the specifics of these sensors are covered in detail by Straube et al. (2002).

- Temperature sensors $\left(10 \mathrm{k}\right.$ NTC thermistors; accuracy $\left.0.4^{\circ} \mathrm{F}\left[0.2^{\circ} \mathrm{C}\right]\right)$

- Relative humidity (RH) sensors (thermoset polymer capacitive-based sensors with onboard signal conditioning (accuracy $\pm 3 \%, 10 \%-90 \% \mathrm{RH}$ )

- Wood moisture content (MC) (in-situ electrical-based resistance measurements between corrosion-resistant insulated pins). Electric resistances were converted into wood MCs using methods described by Straube et al. (2002). Species correction factors were applied when available. A generic OSB species correction was used for the wall sheathing, as opposed to values specific to the manufacturer.

The test wall instrumentation plan is shown in Figure 12; the logic for the selection of sensors is listed below.

- Sheathing $\mathrm{MC}$ is a key indicator for long-term durability and moisture risks; therefore, three sheathing $\mathrm{MC} /$ temperature sensors were installed at each wall (upper/middle/lower).

- The outermost stud MC was monitored at inboard and outboard edges (warm/cold conditions).

- Temperature and RH were monitored at three depths in the stud bay (outboard/middle/inboard), which allows measurement of temperature and humidity gradients.

- The "wafer" sensor was installed at the inboard surface of the exterior sheathing to measure surface humidity conditions at the likely condensing plane. 
- A temperature sensor was installed at the interface between the insulation and the interior gypsum board.

Figure 9 shows typical sensor types and installations. The left-hand image (Figure 9) shows a temperature and wood MC sensor installed at the exterior sheathing. The sensor with red heatshrink tubing is a temperature measurement (thermistor), and the blue wire leads run to wood MC pins.

The right-hand image (Figure 9) shows typical conditions mid-height in the study bay, with $\mathrm{T} / \mathrm{RH}$, sheathing MC, and stud MC sensors visible. The T/RH sensor can be identified by the yellow heat shrink tubing; the sensor consists of a vapor-permeable polyolefin house wrap envelope around the $\mathrm{T} / \mathrm{RH}$ sensor.
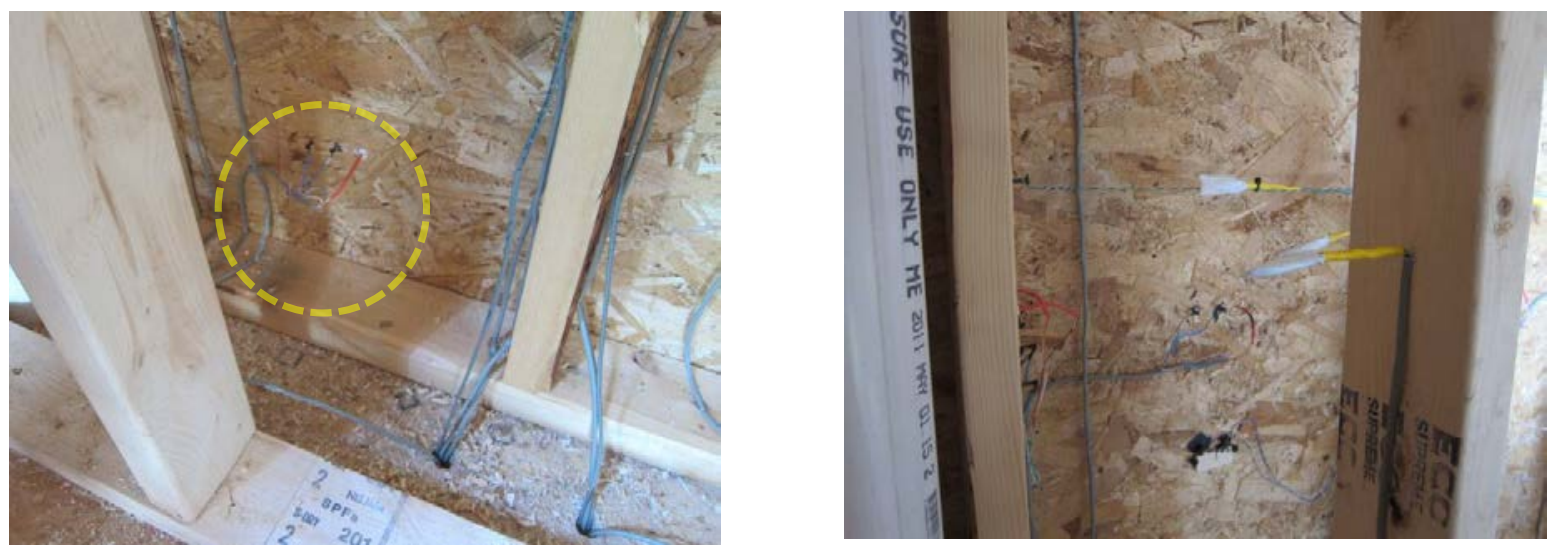

Figure 9. (L) Temperature and MC sensor at sheathing; (R) sensors at mid-height of stud bay

Figure 10 shows a "wafer" sensor (wood-based RH surrogate measurement), installed at the inboard side of the sheathing to measure conditions at the likely condensation plane. Screws were used as temporary clamps to hold the sensor in place until the adhesive set.

The completed installation at the south walls is shown in Figure 11 prior to insulation. Stud bays were chosen to avoid anomalies such as electrical boxes, plumbing pipes, or corners of the building.

ocSPF (0.5 PCF) meets the requirements for an air barrier material at typical stud bay thicknesses (3.5-4.5 in.). Lateral air movement at the cellulose bay is controlled by full-depth spray foam between test bays. The cellulose bay was not gasketed as an isolated bay, but the houses at this development were air sealed with the air drywall approach (caulked bottom and top plates, and window/door openings).

Sensor cables were stapled back to studs or sheathing to minimize thermal bridging and/or insulation displacement effects near the measurement location; cables were run away from the sensor perpendicular to the heat flow path to minimize their effect (Straube et al. 2002). 
The sensor complement was identical in the two 12-in. thick insulation (spray foam and cellulose) wall test bays. At the "shorted" or "control" bay (N3/S3), the sensor count was reduced. There was a "dead" air space between the interior gypsum board and the interior face of the stud bay spray foam. This is not an ideal comparison, but was required to keep the interior gypsum board in plane at this occupied house. T/RH conditions within the void space were recorded directly, for comparison with interior conditions. Only a single temperature sensor was placed between the inner face of the foam and the drywall, because negligible $\mathrm{T} / \mathrm{RH}$ gradients were expected across this void space.

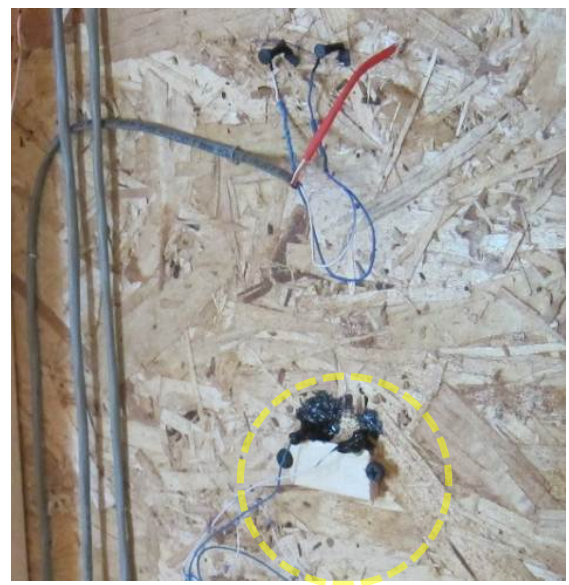

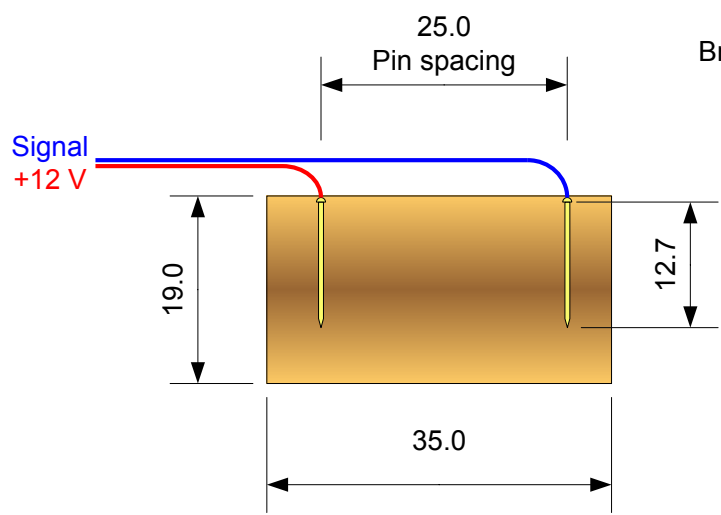

Face view

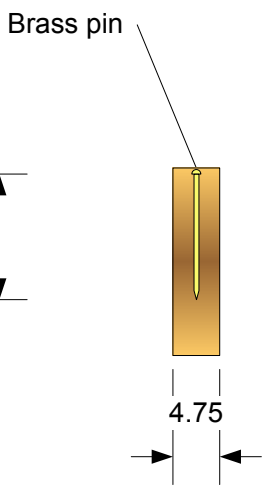

Edge view

Figure 10. (L) Wafer surrogate RH sensor; (R) schematic of sensor, with dimensions (mm)

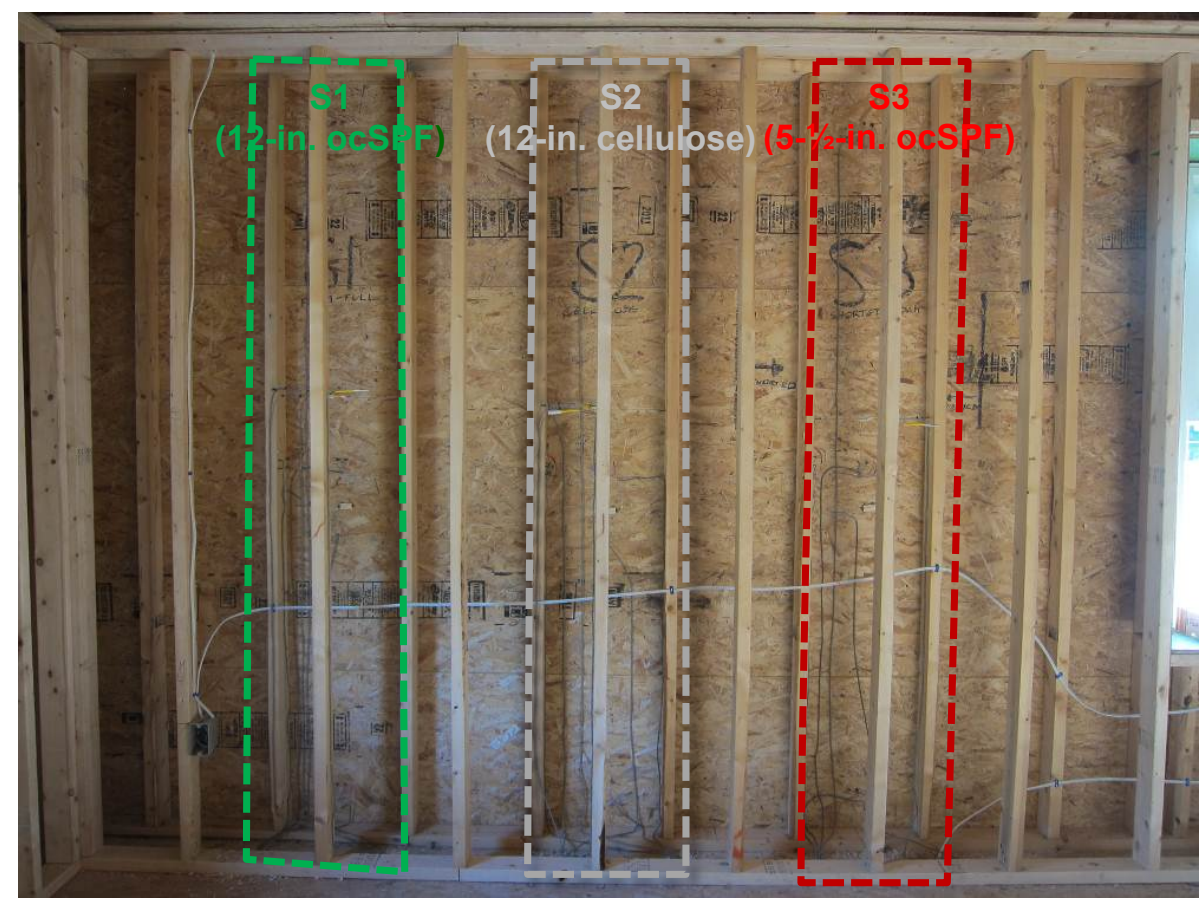

Figure 11. South test walls after installation of sensors, showing double-stud layout

The base of wall N3 was shielded by the garage roof (Figure 8); the sensors at the "lower" sheathing location were shifted upward, to the lowest exterior exposure in the stud bay. 

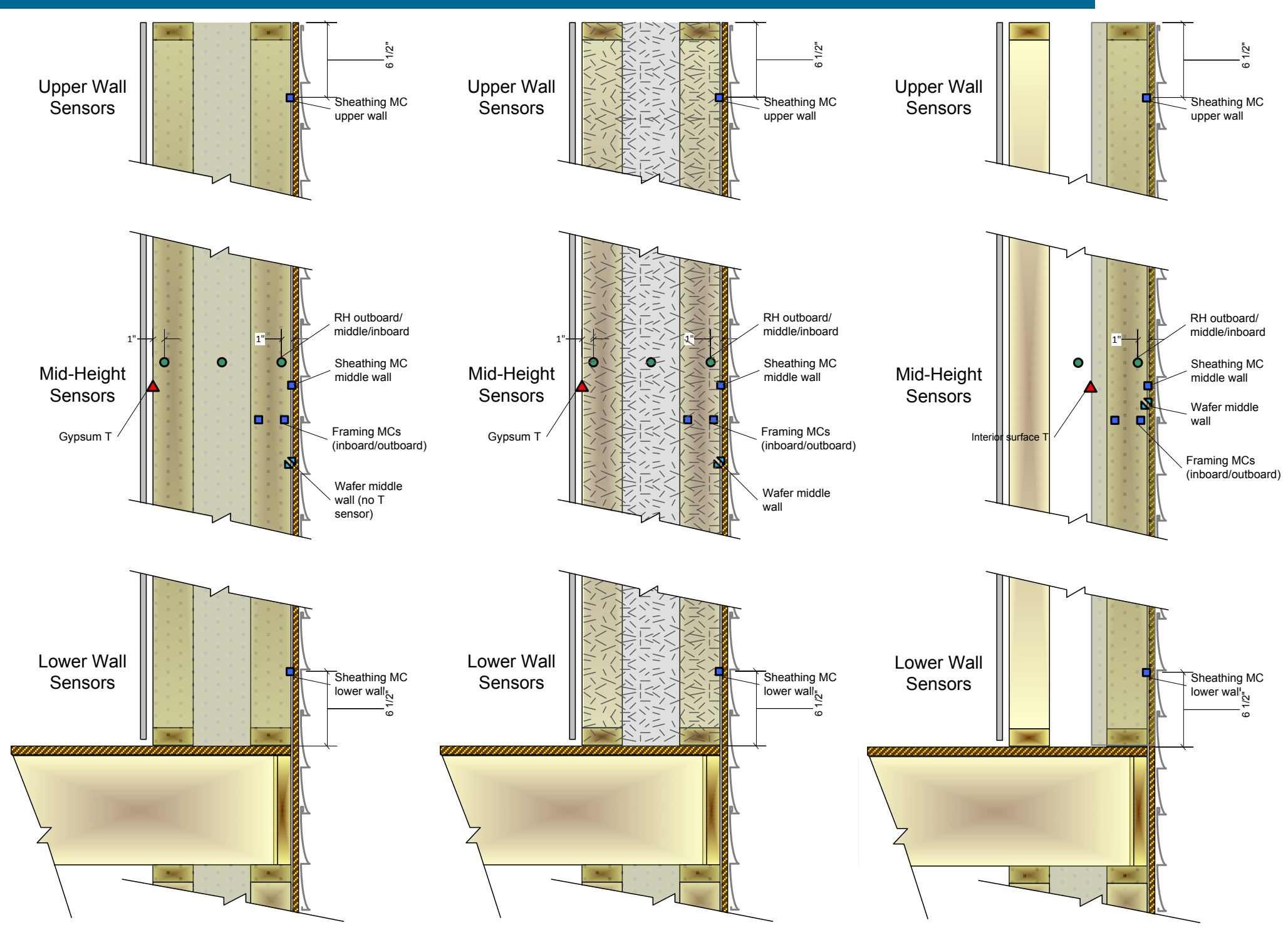

Figure 12. Instrumentation diagram for (L) 12-in. ocSPF; (C) 12-in. cellulose; and (R) $5-1 / 2$ in. ocSPF 


\subsection{Additional Sensors and Data Collection Logistics}

In addition to the sensors in the walls, T/RH sensors were located in the living spaces in the north and south test wall rooms. The enclosure is shown in Figure 13; the locations on the floor plan are shown in Figure 7.
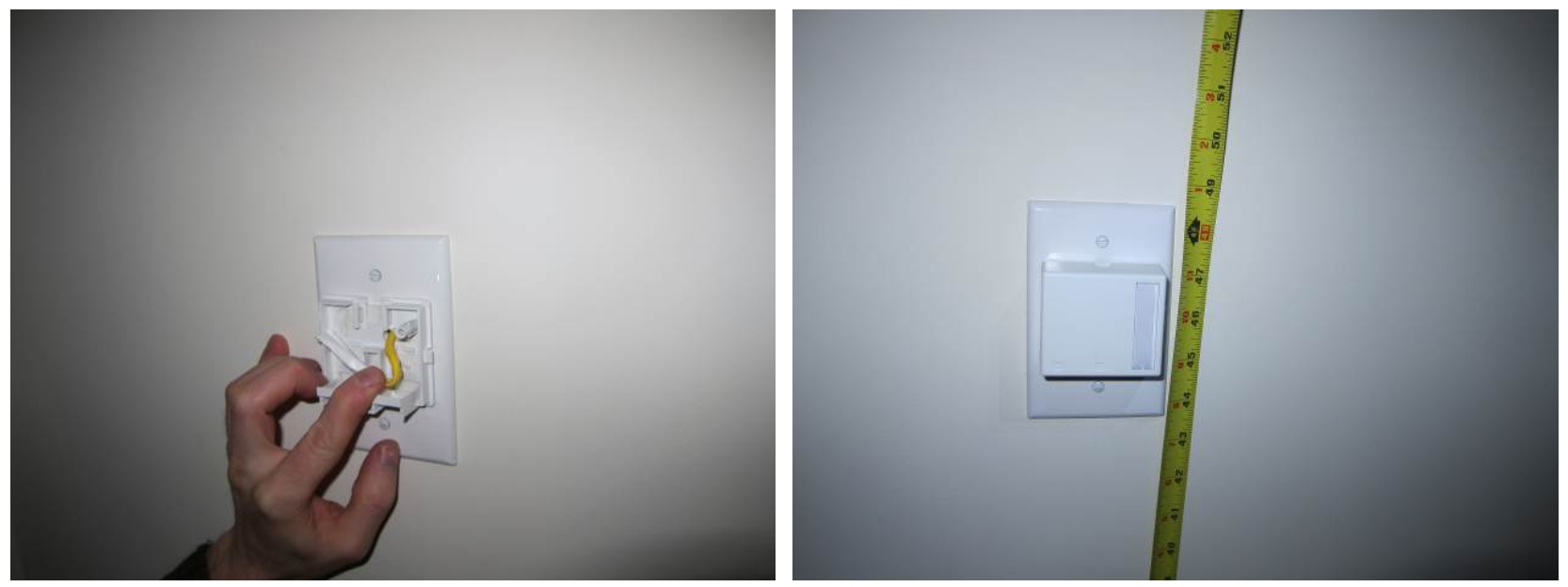

Figure 13. Sensor measure interior (bedroom) T/RH sensors

An exterior T/RH sensor (Figure 14, left) provided outdoor conditions synchronized to the wall measurements; it was located within a solar radiation shield on the north side of the house.

The data logger was located in the basement; data were collected at 5-min intervals, and hourly averages were recorded. No battery backup for the data logger was provided; however, the unit has nonvolatile memory, and resumed data collection after a power failure.
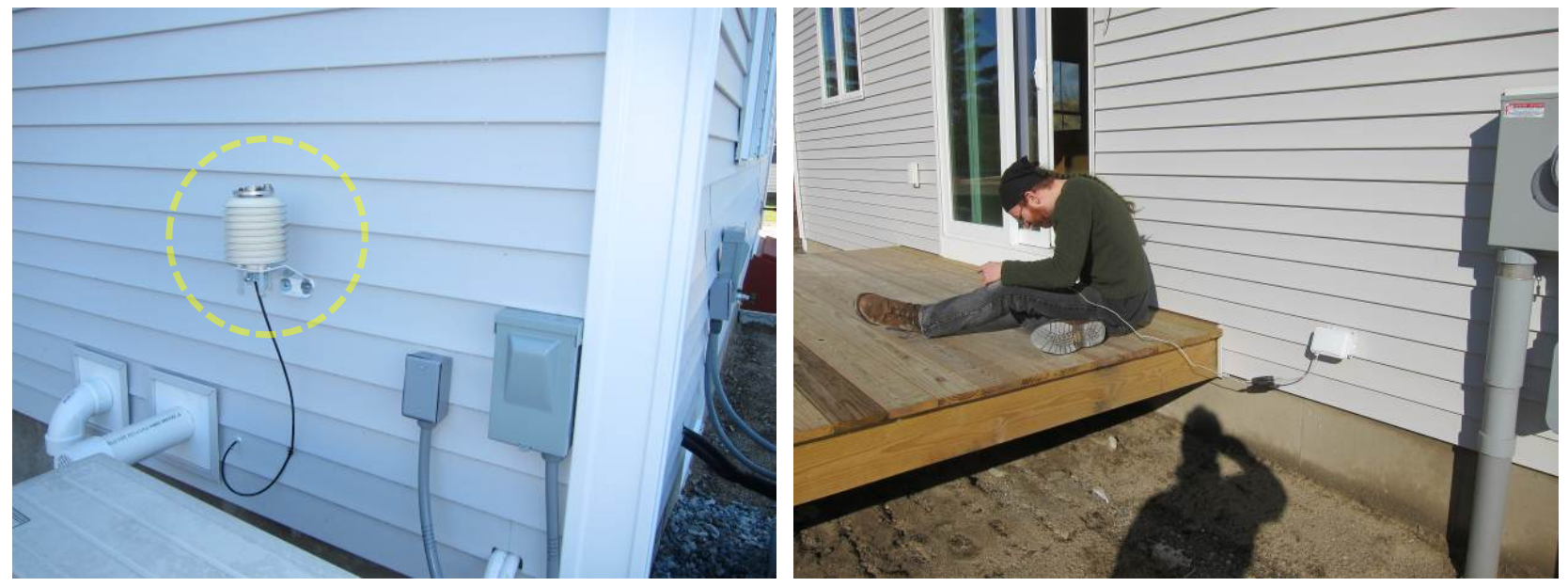

Figure 14. (L) Exterior T/RH sensor; (R) data collection from exterior connection port

An RS-232 serial cable was run through the wall to a weather-tight box mounted on the exterior. This allowed onsite data collection without entering the house, as shown in Figure 14, right. 


\section{Monitoring Results}

\subsection{Data Overview and Boundary Conditions}

Data were collected from December 2011 through July 2014, or roughly 32 months. This captures data from three winters (one partial winter) of operation in various states.

Interior and exterior temperatures are shown in Figure 15. Interior winter temperatures held steady in the north and south bedrooms in the $65^{\circ}-72^{\circ} \mathrm{F}\left(18^{\circ}-22^{\circ} \mathrm{C}\right)$ range, except for a period in March 2012 when the heating system was inadvertently turned off. Interior temperatures in winter 2013-2014 were slightly warmer than in previous winters.

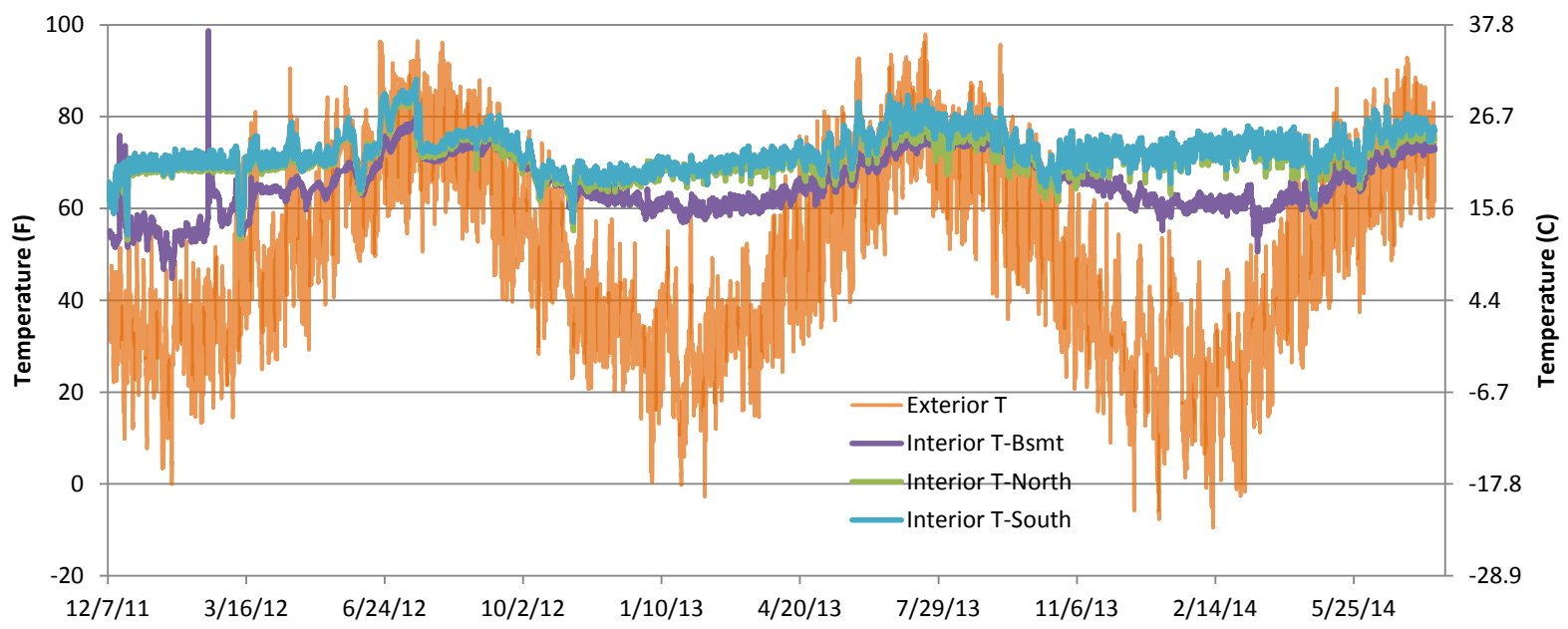

Figure 15. Exterior and interior (test rooms and basement) temperatures

Exterior temperatures varied by winter:

- Winter 2011-2012 was exceptionally mild (warmer than normal): 5220 HDD base $65^{\circ} \mathrm{F} / 2900 \mathrm{HDD}$ base $18^{\circ} \mathrm{C}$ versus $6220 / 3455 \mathrm{HDD}$ climate normal for Fitchburg, Massachusetts.

- Winter 2012-2013 was closer to normal (6050 HDD $\left.65^{\circ} \mathrm{F} / 3360 \mathrm{HDD} 18^{\circ} \mathrm{C}\right)$.

- Winter 2013-2014 was colder than climate normal (6730 HDD 65ำ/3740 HDD $18^{\circ} \mathrm{C}$ ); this was the winter of the "polar vortex."

For reference, the monthly HDD for Fitchburg, Massachusetts, airport (KFIT, roughly 9 miles from the Devens site) are plotted in Figure 16, with annual HDD tabulated. 


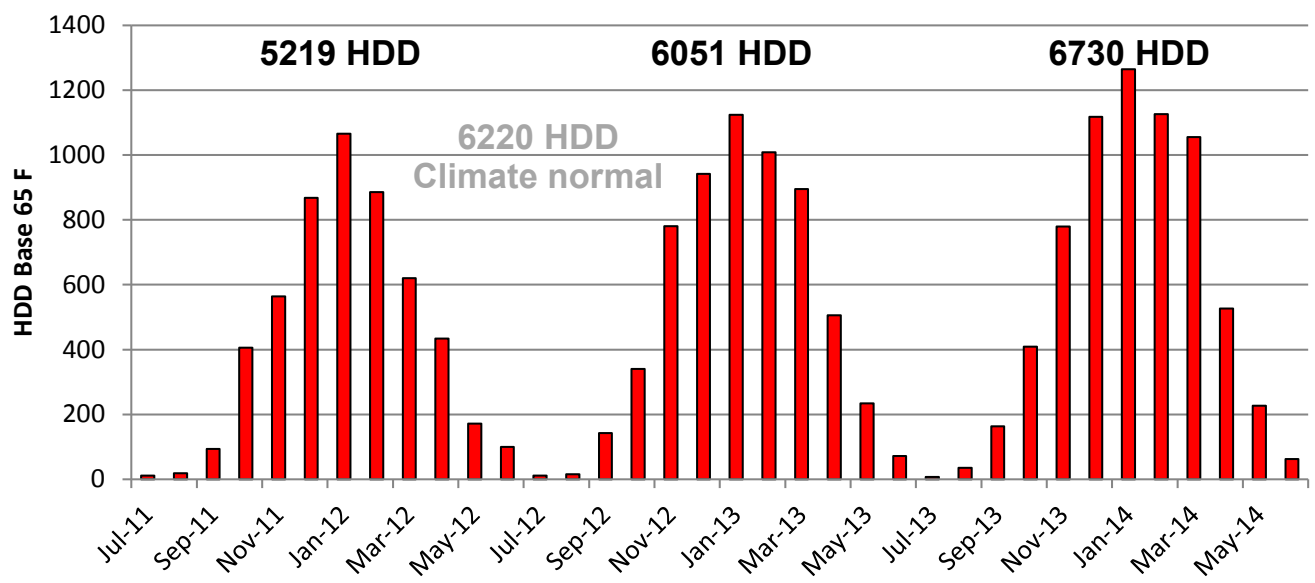

Figure 16. HDD $\left(65^{\circ} \mathrm{F}\right)$ for Fitchburg, Massachusetts airport (KFIT)

Interior RH conditions are shown in Figure 17; there were different interior conditions for each of the three winters.

- Winter 2011-2012 (partial): interior wintertime RH levels fell to the $10 \%-20 \%$ range for much of the winter, which were exceptionally dry conditions. There was no occupancy during this winter, and therefore no interior moisture generation (occupants showering, cooking), thus explaining the low RH levels. However, construction moisture was drying during the winter. Basement RH levels were higher, as would be expected with lower temperatures.

- Winter 2012-2013: the house was occupied by a family of four, and the ventilation system was not operated consistently; in addition, the house is very airtight (1.1 air change per hour at 50 Pascals/ACH50). This resulted in high wintertime humidity levels of $40 \%-50 \%$ for most of the early winter. The ventilation system was put in operation in late winter (mid-February 2013; gray line), resulting in lower interior RHs $(20 \%-35 \%)$.

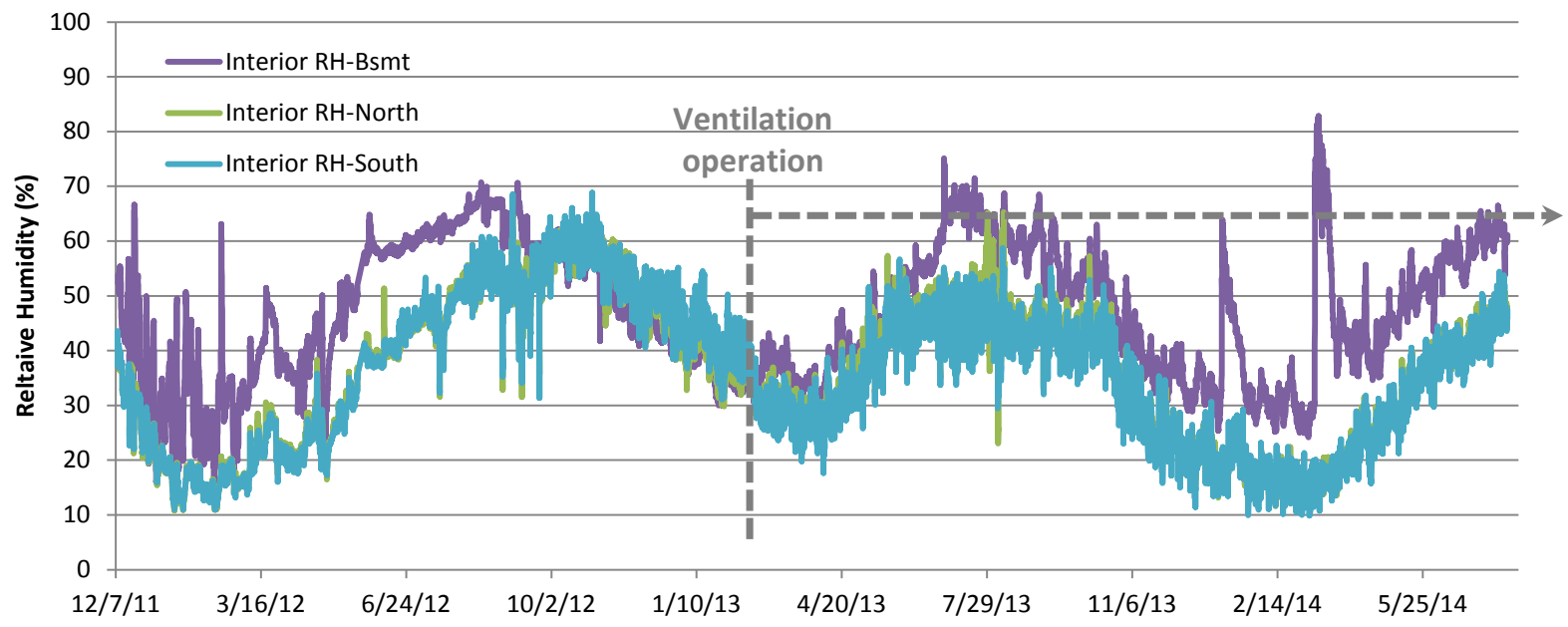

Figure 17. Interior RHs (test rooms and basement); ventilation operation shown 
- Winter 2013-2014: the third winter had the same occupancy conditions, but the ventilation system was operated continuously. This resulted in wintertime RH levels in the $10 \%-30 \%$ range. There were two spikes in basement RH levels; they were caused by basement flooding issues from snow buildup.

Interior $\mathrm{T} / \mathrm{RH}$ conditions were used to generate dew point temperatures (absolute air MC), which were plotted with outdoor dew points (Figure 18). Interior moisture conditions essentially tracked outdoor conditions in the first winter, as would be expected without interior moisture generation. But in the second winter, interior dew points were higher in early winter $\left(40^{\circ}-50^{\circ} \mathrm{F}\right.$ $\left.\left[4^{\circ}-10^{\circ} \mathrm{C}\right]\right)$, with drier conditions after ventilation $\left(30^{\circ}-40^{\circ} \mathrm{F}\left[-1^{\circ}\right.\right.$ to $\left.\left.10^{\circ} \mathrm{C}\right]\right)$. The third winter had dew points between these extremes, consistent with an occupied, airtight house with an operating ventilation system.

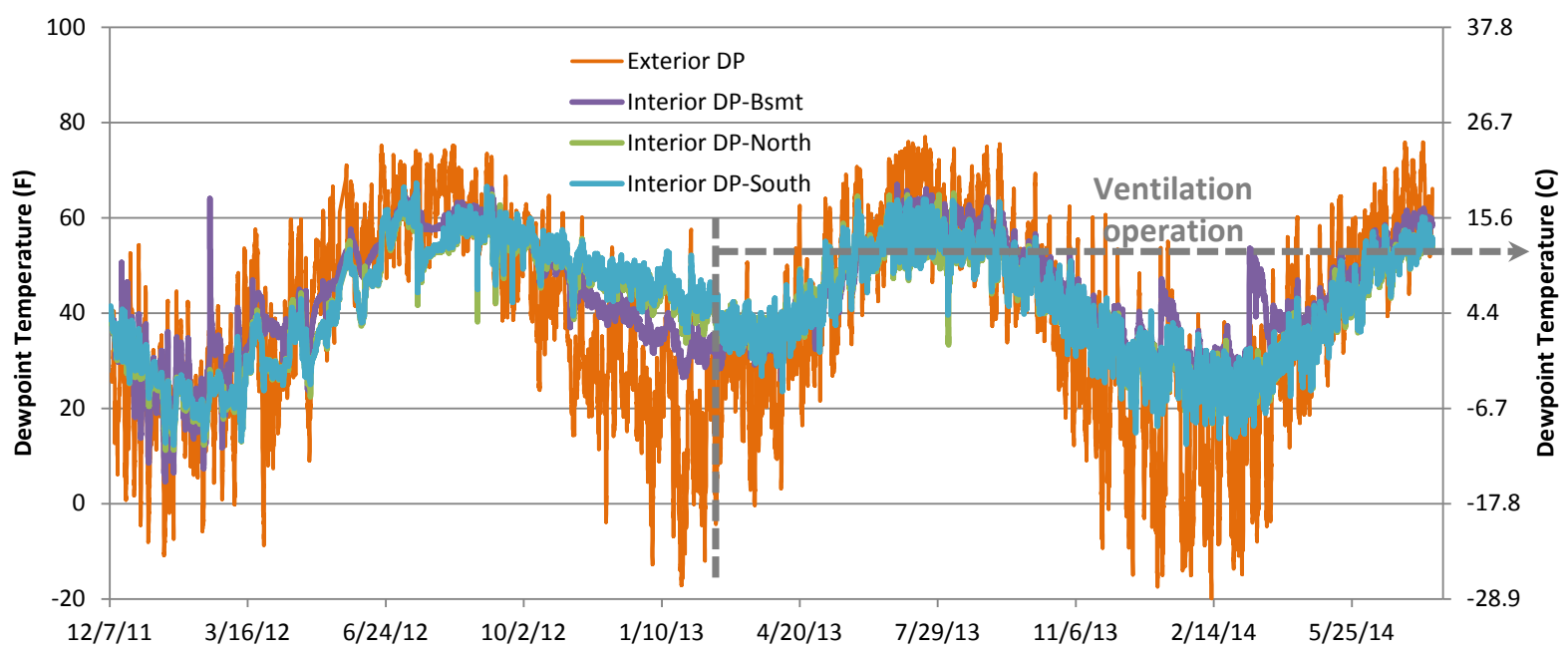

Figure 18. Exterior and interior (test rooms and basement) dew point temperatures

To summarize the three winters (key seasons for sheathing condensation and high MCs) that these test walls have experienced:

- Winter 2011-2012: mild winter, very low interior RH caused by lack of occupancy (partial winter starting in December 2011)

- Winter 2012-2013: colder winter, very high (40\%-50\%) interior RH until ventilation system running in mid-February 2013.

- Winter 2013-2014: very cold winter (“polar vortex"), operating ventilation system, moderate interior RHs.

\subsection{Sheathing Moisture Content Levels}

Sheathing MCs are often used as a primary performance indicator of moisture risks. The sheathing is typically used because it operates near outdoor temperatures, and is often the vulnerable condensing surface for interior moisture in wintertime. The sheathing $\mathrm{MC}$ sensor locations are shown in Figure 19. 

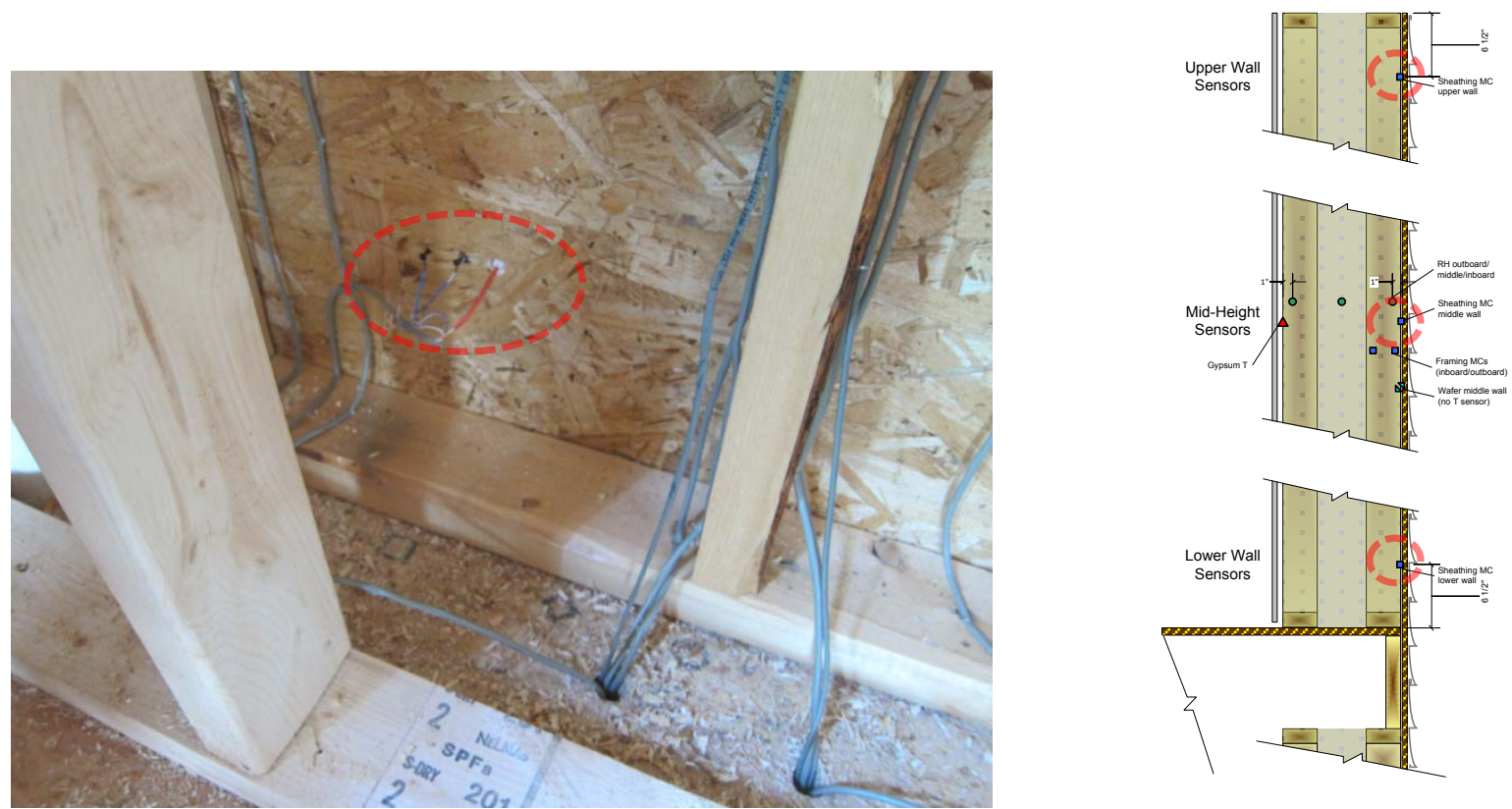

Figure 19. Sheathing MC/temperature sensor locations (bottom shown in picture)

Sheathing MCs for the north-facing walls are shown in Figure 20; they show the expected seasonal rise and fall, with peak MCs in wintertime. The three winter boundary conditions resulted in different responses from the walls:

- In the first winter (with low interior RH levels and mild outdoor temperatures), the north 12-in. ocSPF wall (N1) showed a peak wintertime sheathing MC near $12 \%-15 \%$; the 5$1 / 2$-in. ocSPF wall (N3) was similar to N1, but with slightly higher peak MCs $(15 \%-20 \%)$. However, the 12-in. cellulose wall (N2) showed considerably higher MCs, in the $20 \%-$ $28 \%$ range. In the following summer, MCs fell to the safe range $(10 \%-12 \% \mathrm{MC})$.

- However, the second winter (with interior RH levels in the 40\%-50\% range) resulted in much higher sheathing MCs. The north 12-in. ocSPF wall (N1) showed a peak wintertime sheathing MC near 20\%-26\%; the 5-1/2-in. ocSPF wall (N3) had similar behavior to N1 (24\%-26\% peaks). However, the 12-in. cellulose wall (N2) showed very high MCs, in the 25\%-33\% range. Again, in the following summer, MCs fell to the safe range $(10 \%-12 \% \mathrm{MC})$.

- In the third winter (moderate interior $\mathrm{RH}$, cold outdoor conditions), behavior was similar to the first winter. The north 12-in. ocSPF wall (N1) showed a peak wintertime sheathing MC near 15\%-18\%; the 5-1/2 in. ocSPF wall (N3) was slightly drier than N1, with peak MCs of 15\%-16\%). Again, the 12-in. cellulose wall (N2) had higher MCs, in the 15\%$23 \%$ range, but were much drier than the second winter. Also, all walls dried to safe levels in the summer. 

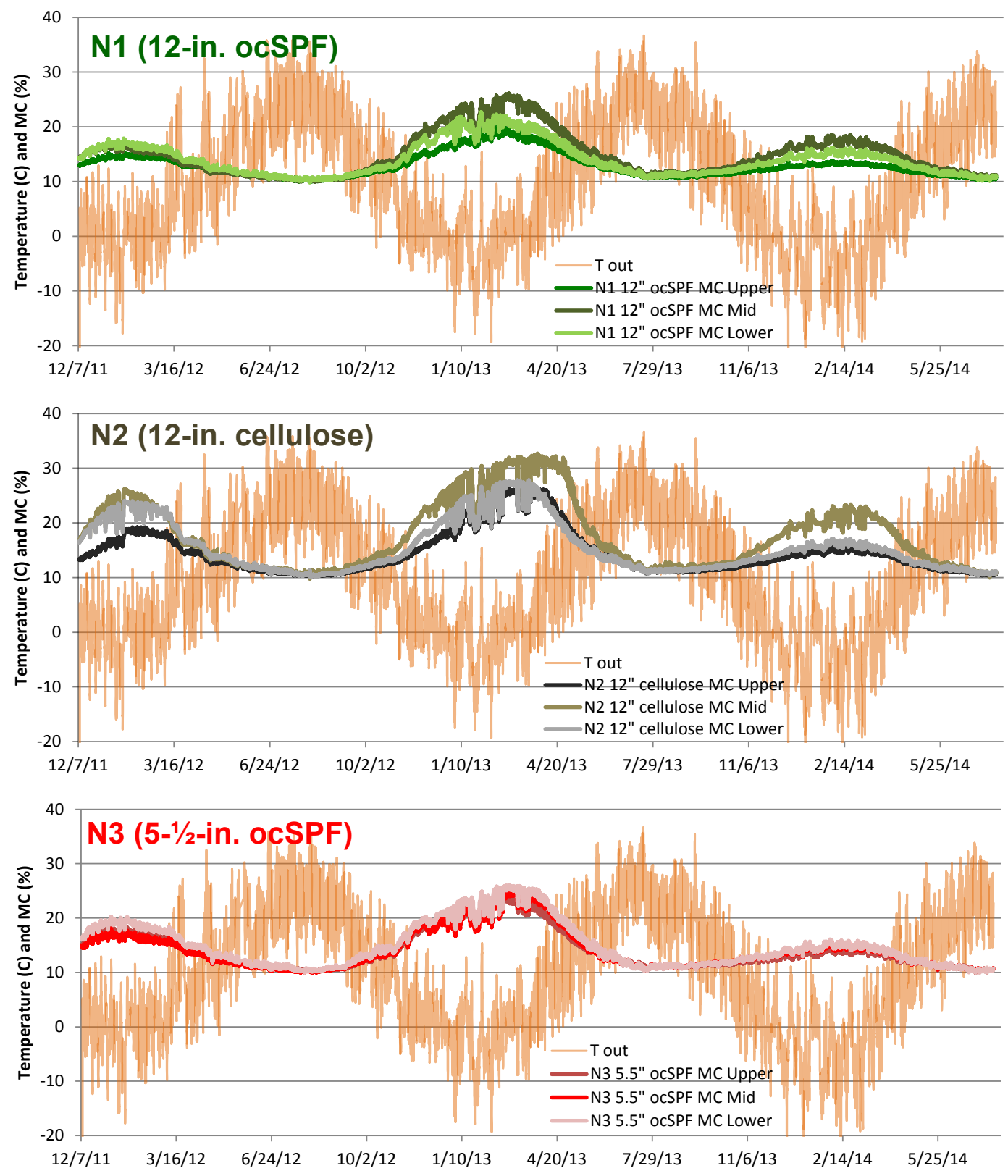

Figure 20. North side sheathing MCs, with exterior temperature for reference

Sheathing MC measurements exceeded the fiber saturation point in some cases: $30 \% \mathrm{MC}$ typical for solid wood (Glass and Zelinka 2010), but were lower in adhered wood products such as OSB (Glass 2013), in the $25 \%-26 \%$ range. From the fiber saturation point up to the capillary saturation, the relationship between MC and electrical resistance is not well defined (James 1988), so the plotted values should not be taken as absolute measurements. However, the high values are useful to show greater wetness levels than lower values.

The MC anomalies seen in the second winter at high MC levels (sudden jumps in MC) coincided with freezing temperatures; freezing of water in the sheathing likely resulted in different 
electrical resistance response (and thus measured $\mathrm{MC}$ ). The $\mathrm{MC}$ trends during nonfreezing temperatures were more representative of actual conditions.

The south-facing walls were all considerably drier than the north-facing walls, but with a similar pattern, where the 12-in. cellulose wall (S2) had higher wintertime peak MCs (Figure 21). In the second winter, the cellulose MCs rose to the $17 \%-30 \%$ range: this was much higher than the ocSPF walls. All walls dried to the $8 \%$ range in the summer; the intermittent data seen during summertime indicated periods drier than the measurement range of the data logger (wood electrical resistance was too high for measurement).
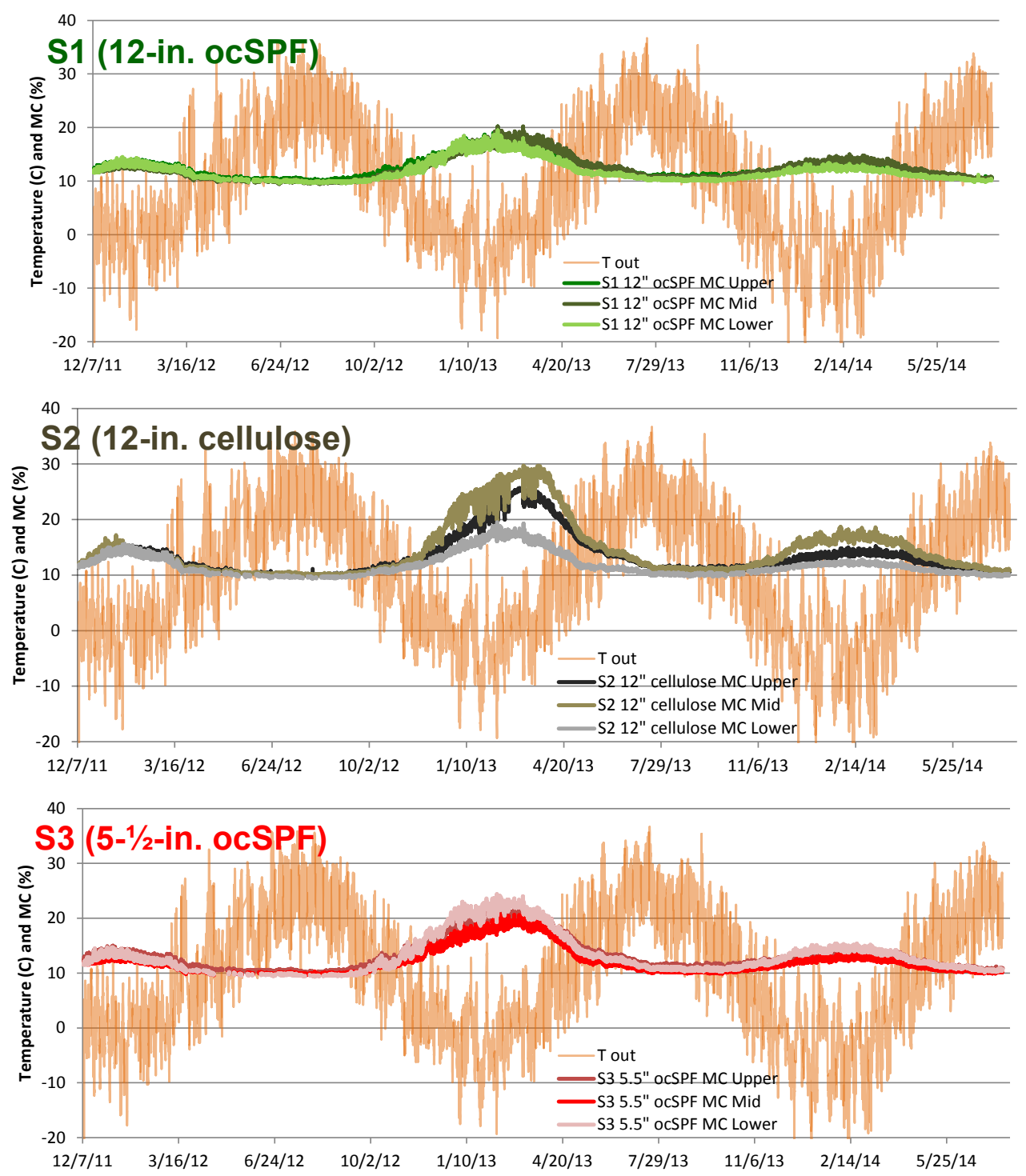

Figure 21. South side sheathing MCs, with exterior temperature for reference

Given the low, middle, and high sheathing MC measurements, the data were examined for evidence of spatial MC relationships. The mid-height MC was noticeably higher in some cases; the upper MC was lowest in two of three cases: this would be an argument against convective 
airflow depositing moisture at the top of the stud bay. The upper sheathing might have been slightly shielded from night sky radiation by the roof overhang, resulting in warmer sheathing temperatures (and lower MCs). Tthis is consistent with temperature measurements.

\subsection{Moisture Content Wafer Sensors}

Other sensors were used to corroborate the sheathing $\mathrm{MC}$ behavior. The wafer sensors reflected conditions at the exterior sheathing-to-insulation interface (Figure 22).
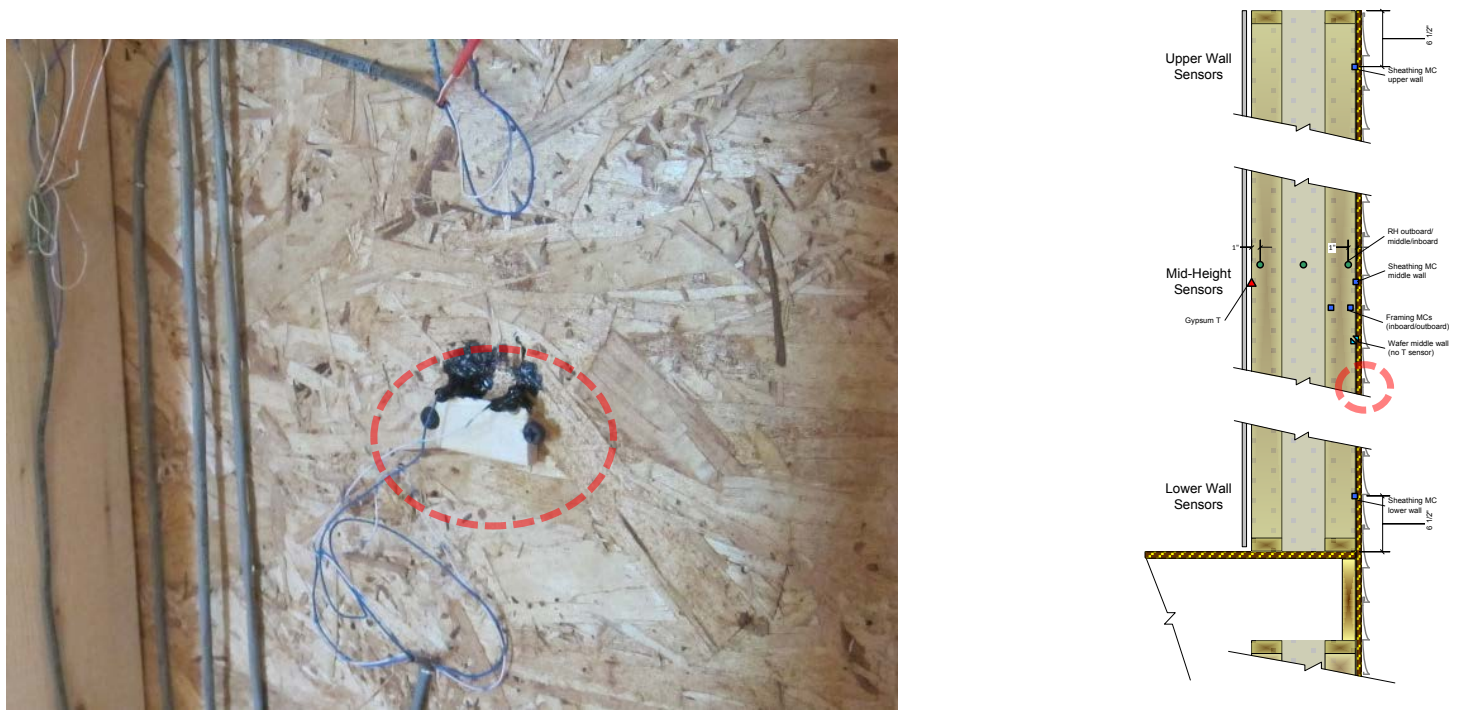

Figure 22. Sheathing-insulation interface wafer sensor location

Results for the three north-facing walls are plotted in Figure 23. The response of these woodbased sensors should be understood when interpreting these results. In a previous calibration (Ueno and Straube 2008), the wafer sensors came to equilibrium with 100\% RH conditions (air in closed container over water) at 28\%-30\% MC (blue dotted line in Figure 23 through Figure 26). However, immersing the sensors in liquid water increased their MC to the $40 \%-45 \%$ range. Therefore, measurements above the $100 \% \mathrm{RH}$-equivalent range indicate liquid water condensation.

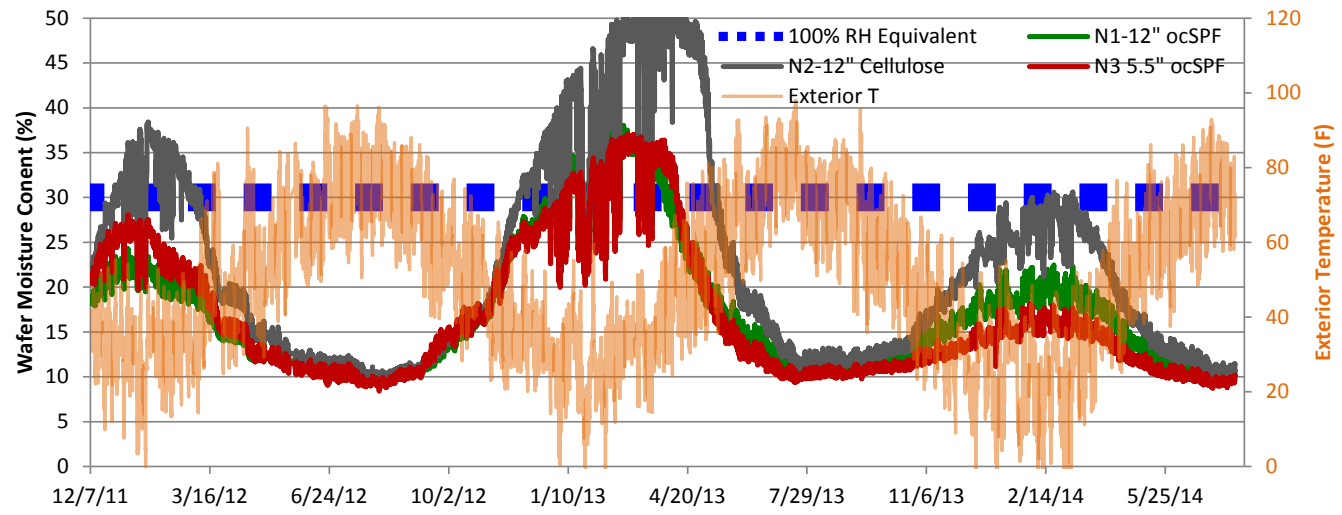

Figure 23. North side wafer sensor MCs, with exterior temperature for reference 
The wafer response is consistent with the sheathing MC measurements, as shown in the northside measurements (Figure 23):

- In the first winter, 12 in. of ocSPF remained the driest through the winter, followed by 5 $1 / 2$-in. ocSPF. The cellulose wall showed much higher wintertime peak moisture levels, consistent with condensation occurring at the sheathing (higher than the $100 \%$ equivalence line). In contrast, the open foam walls remained below the $100 \% \mathrm{RH}-$ equivalence level. During the following summer, all wafer sensors dried to the $9 \%-12 \%$ $\mathrm{MC}$ range $(50 \%-65 \% \mathrm{RH}$ equivalent).

- In the second winter, all wafer sensors showed MC peaks well into the condensation range, with significant condensation at the 12-in. cellulose wall. Again, the wafers dried in the following summer, because thermal gradients drove moisture inward.

- In the third winter, similar patterns to the first winter are seen, except that $12 \mathrm{in}$. of ocSPF (N1) and 5-1/2-in. ocSPF (N3) changed order (although both were well below $100 \% \mathrm{RH}$ ).

The wafer MC measurements also showed anomalies during freezing conditions; the peak values should be considered to be most representative. Figure 24 shows the same data, but filtered for values when sheathing temperatures were above the freezing point $\left(35.6^{\circ} \mathrm{F}\left[2^{\circ} \mathrm{C}\right]\right.$ used here); there was a significant reduction in wintertime anomalies.

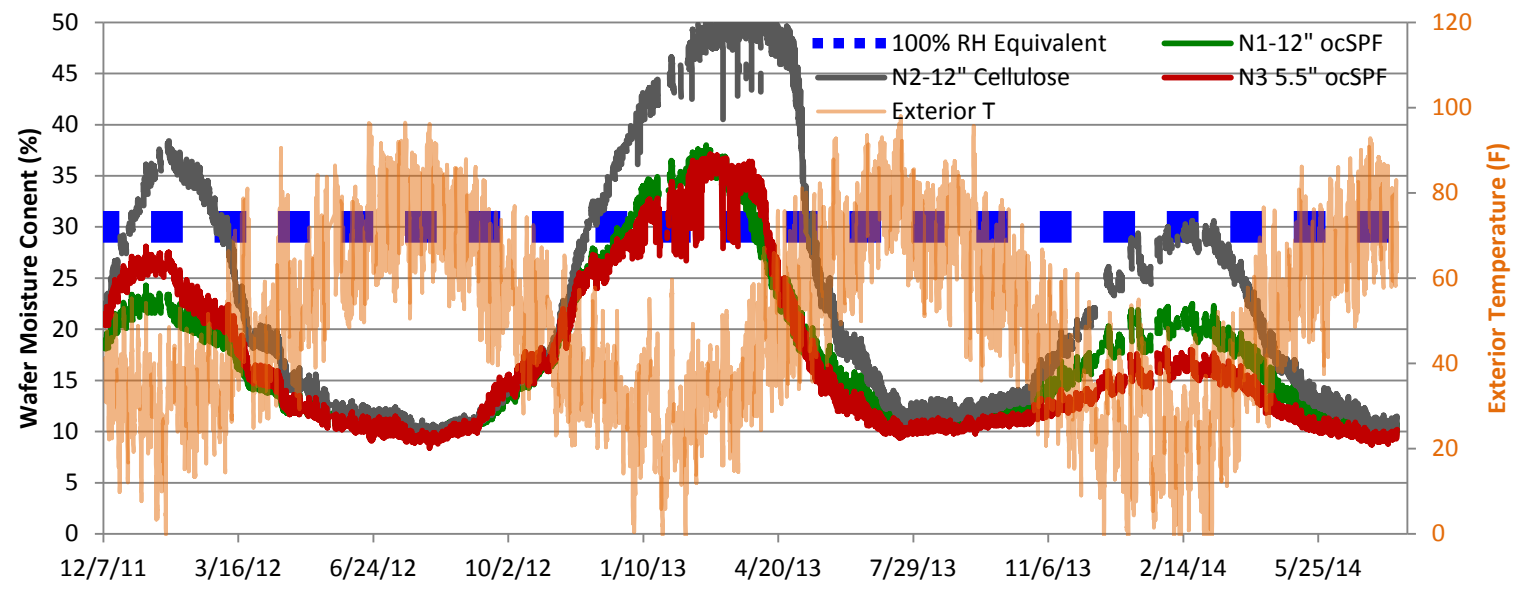

Figure 24. North side wafer sensor MCs, filtered values above $36^{\circ} \mathrm{F}$

The south-facing wall wafer results are shown in Figure 25; again, patterns are analogous to the previous sheathing MC measurements. The cellulose wall showed the highest moisture levels, but was drier than the north walls. In the second winter, significant condensation was indicated in the cellulose wall; again in the following summer, the wafers returned to the dry range. In the third winter, all measurements were below $100 \% \mathrm{RH}$ equivalent. Also, during each summer, the wafers dried to roughly $10 \% \mathrm{MC}$, which is well into the safe range. 


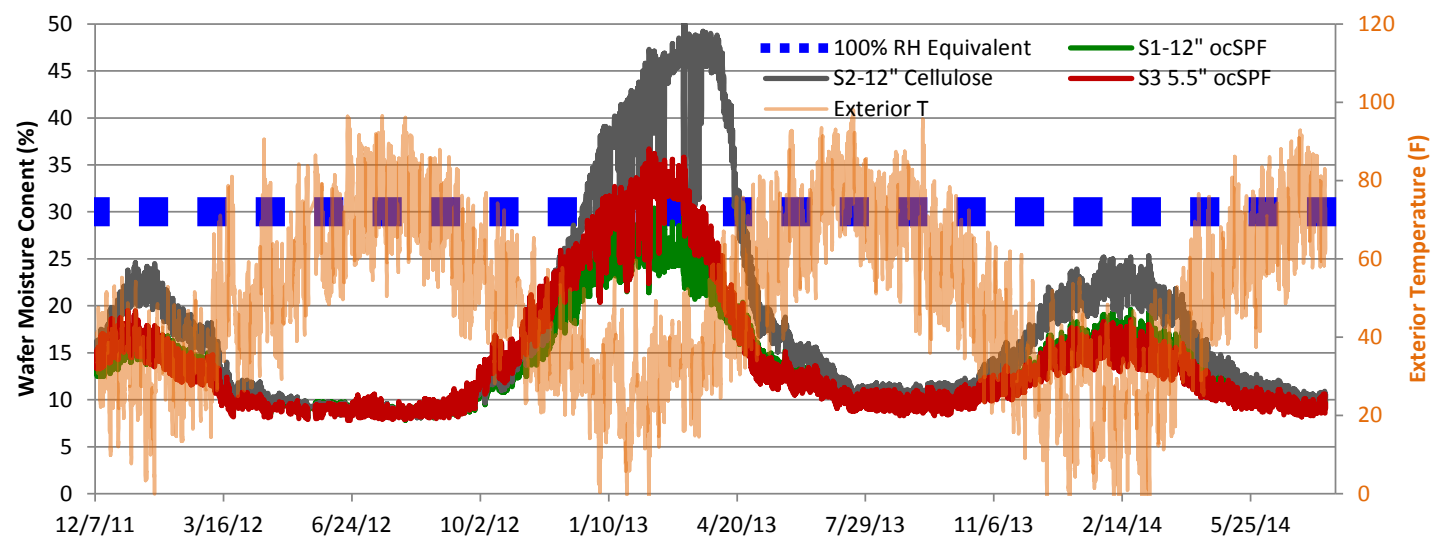

Figure 25. South side wafer sensor MCs, with exterior temperature for reference

The values were again filtered for sheathing temperatures above freezing $\left(35.6^{\circ} \mathrm{F}\left[2^{\circ} \mathrm{C}\right]\right.$ used here) in Figure 26; there was a similar reduction in anomalies.

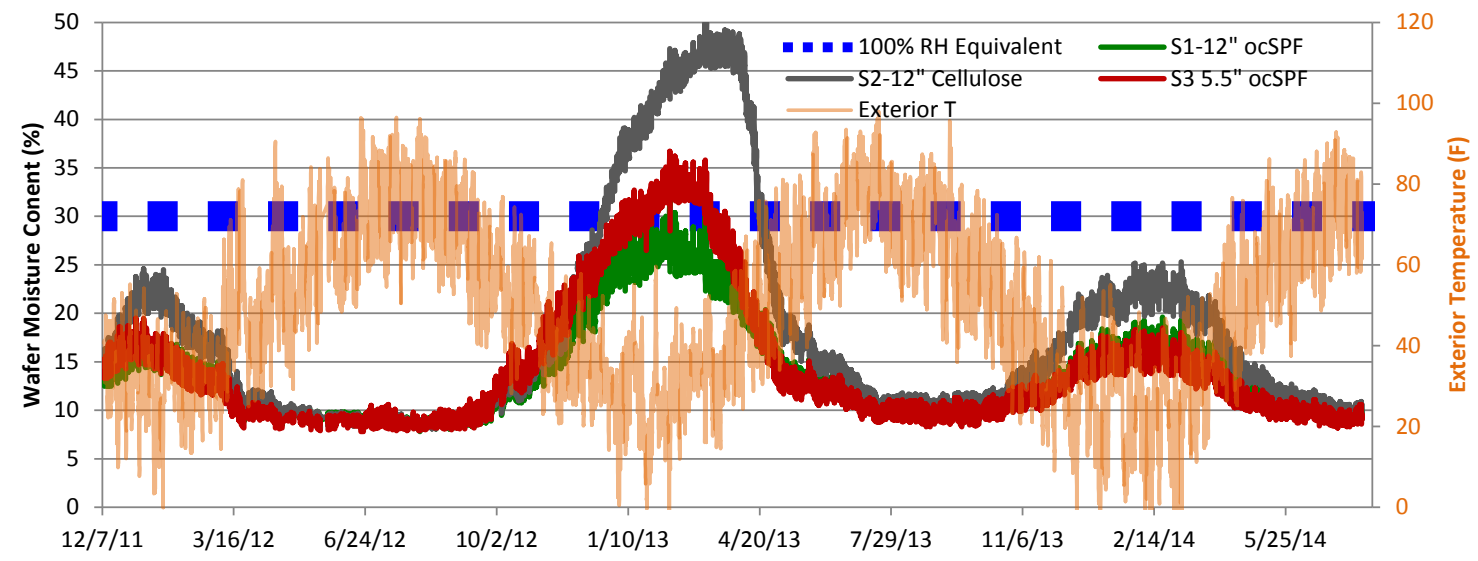

Figure 26. South side "wafer" sensor MCs, filtered values higher than $36^{\circ} \mathrm{F}$

\subsection{Wall Cavity Relative Humidity}

RH measurements further corroborate the MC measurements. As shown in Figure 27, T/RH sensors were located at the exterior, middle, and interior of each stud bay.

The RH measurements for the north-facing walls (outboard side) are plotted in Figure 28. The $\mathrm{T} / \mathrm{RH}$ sensor was installed roughly $1 / 2$ in. away from the face of the exterior sheathing. 

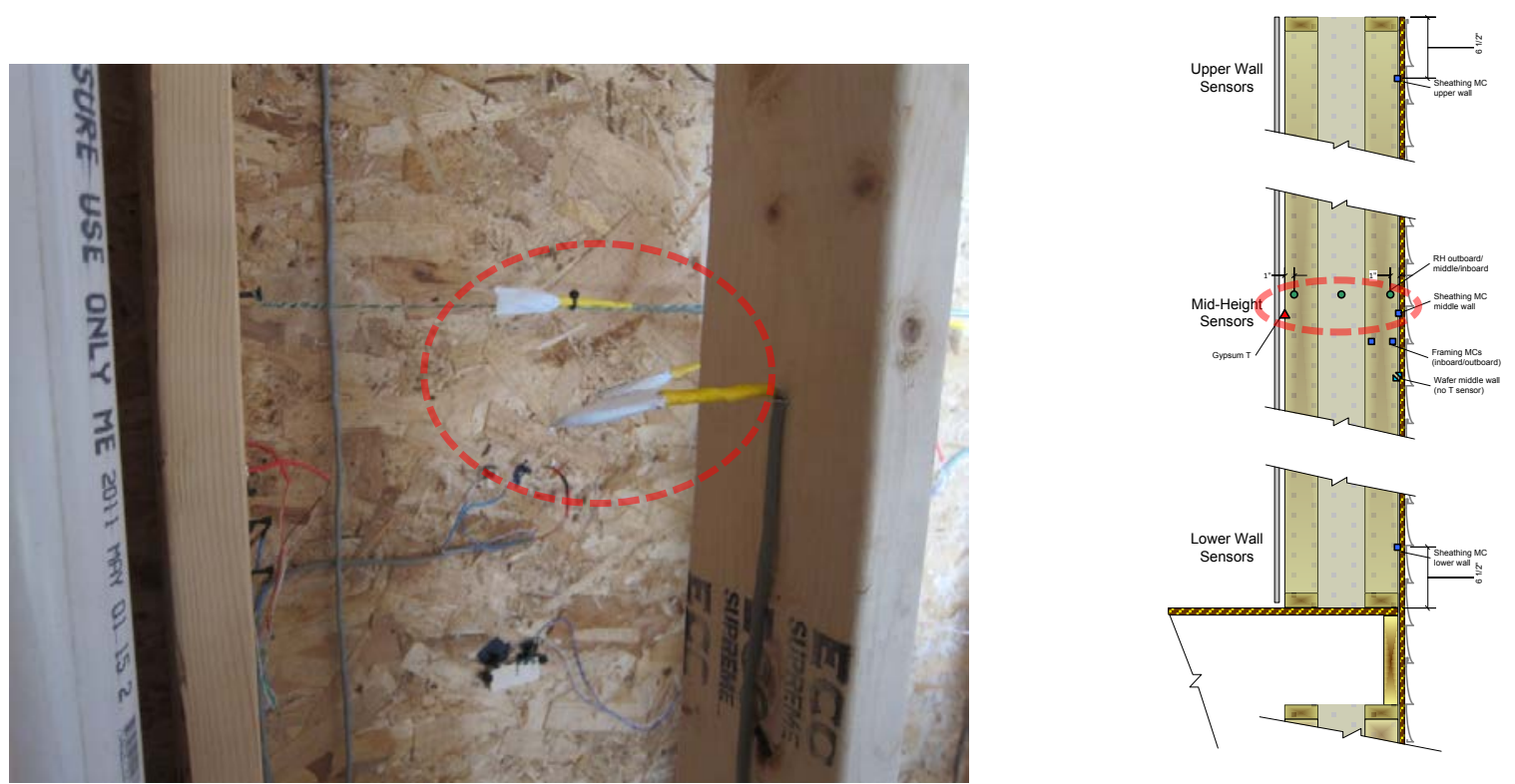

Figure 27. Stud bay cavity T/RH sensor locations

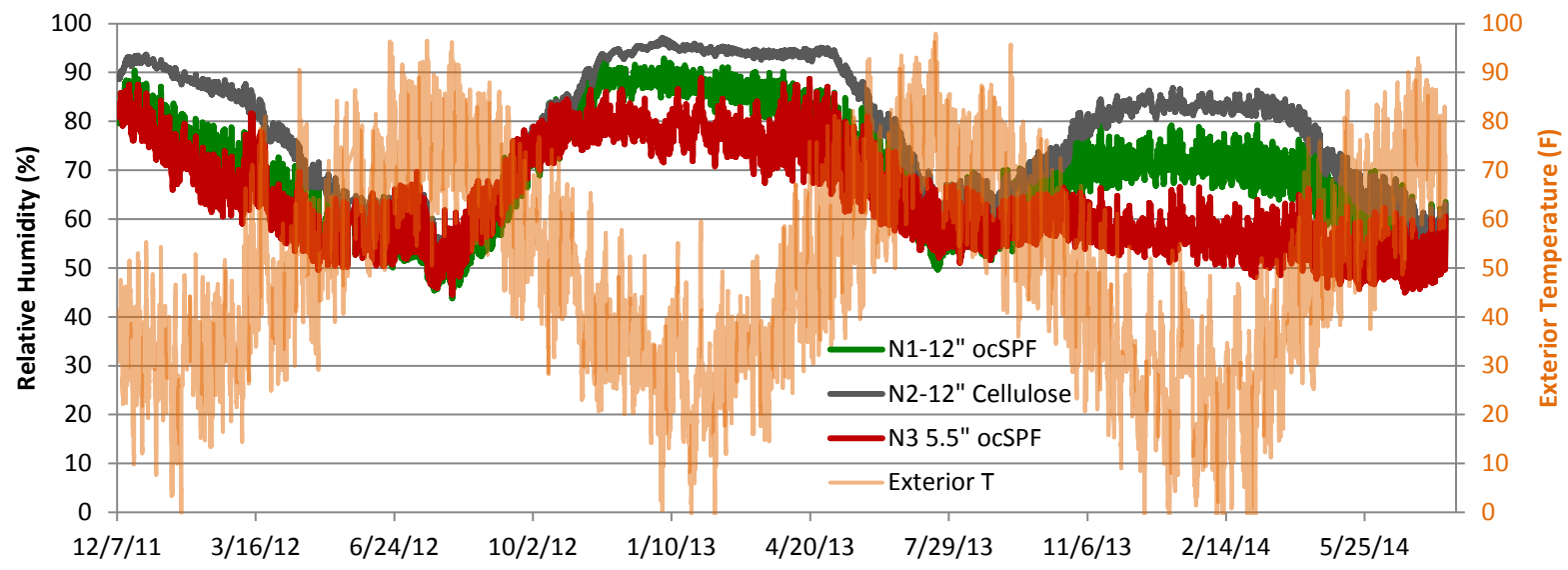

Figure 28. North-facing wall exterior side RH, with exterior temperature for reference

The temperatures at the RH sensors followed the expected wintertime pattern: N1 and N2 were close to identical (tracking outdoor conditions), and N3 was slightly warmer (because of reduced insulation inboard of the sensor).

The relative order of RHs was similar to what was seen in the wafer data, with the cellulose (N2) consistently the wettest, and the 5-1/2-in. os SPF (N3) typically driest. During the second winter (high interior $\mathrm{RH}$ ), the $\mathrm{RH}$ at the cellulose wall was roughly $95 \%$ for most of the winter. During the summers, all RH sensors at the sheathing fell to the $50 \%-70 \%$ range, because the temperature gradient and moisture drive were inward, away from the sheathing.

The inboard RH sensors for the north-facing walls are plotted in Figure 29, with exterior temperature and interior RH for reference. The RH levels essentially tracked interior conditions. The void space inboard of N3/S3 (5-1/2-in. ocSPF) showed similar behavior. 


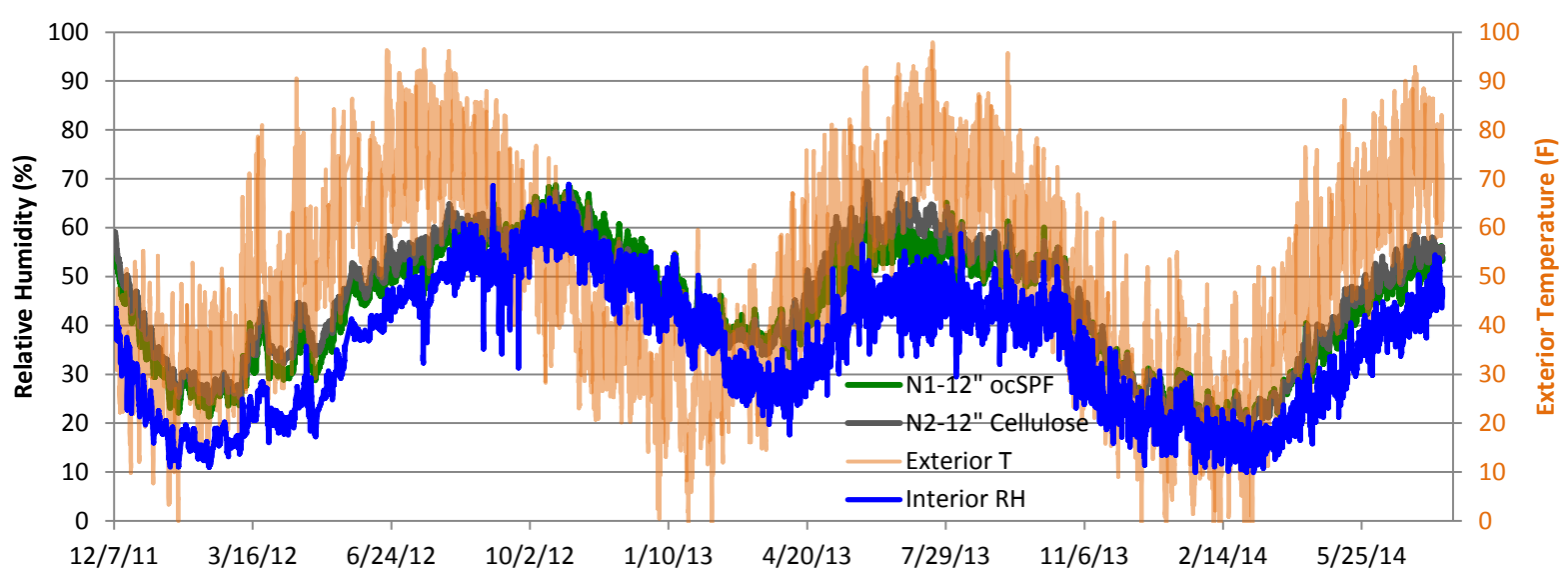

Figure 29. North-facing wall interior side RH, with interior $\mathrm{RH}$ and exterior temperature for reference

In the summers, when the walls dried inward, there was no sign of moisture accumulation at the inboard side of the wall. This was due to the vapor-open nature of the interior finishes (latex paint on gypsum board, Class III vapor retarder).

\subsection{Framing Moisture Content Levels}

The framing MC sensors (inboard/outboard side of outer stud) are shown in Figure 30; they were compared to previous measurements for consistency.
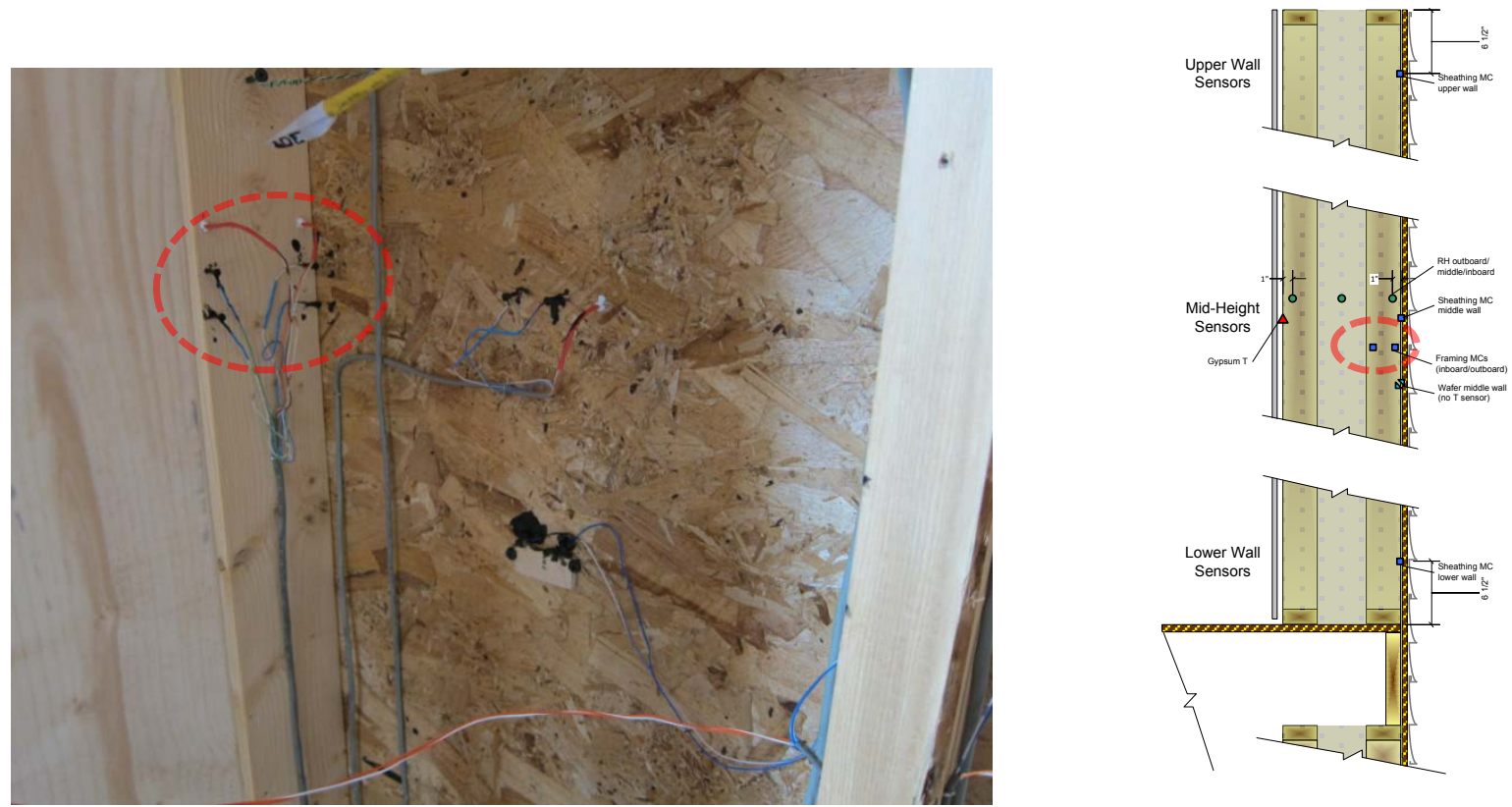

Figure 30. Framing MC/temperature sensor locations

The relationships between the test walls were again similar, with north walls wetter than the south, cellulose wetter than ocSPF walls, and outboard MCs higher than inboard MCs. Peak MCs were generally lower in the framing than the sheathing measurements. In the second winter 
(worst wetting), the north cellulose outboard framing peaked at 20\%-25\%, while the two ocSPF walls peaked near $16 \%-18 \%$.

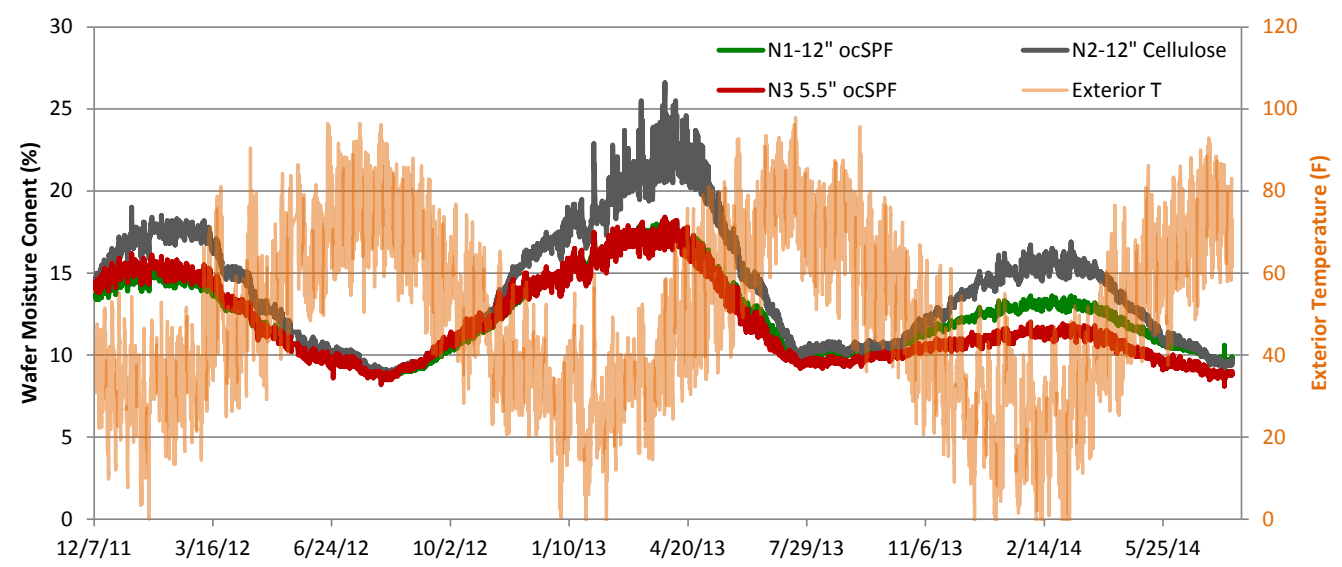

Figure 31. North-facing wall exterior framing MC, with exterior temperature for reference

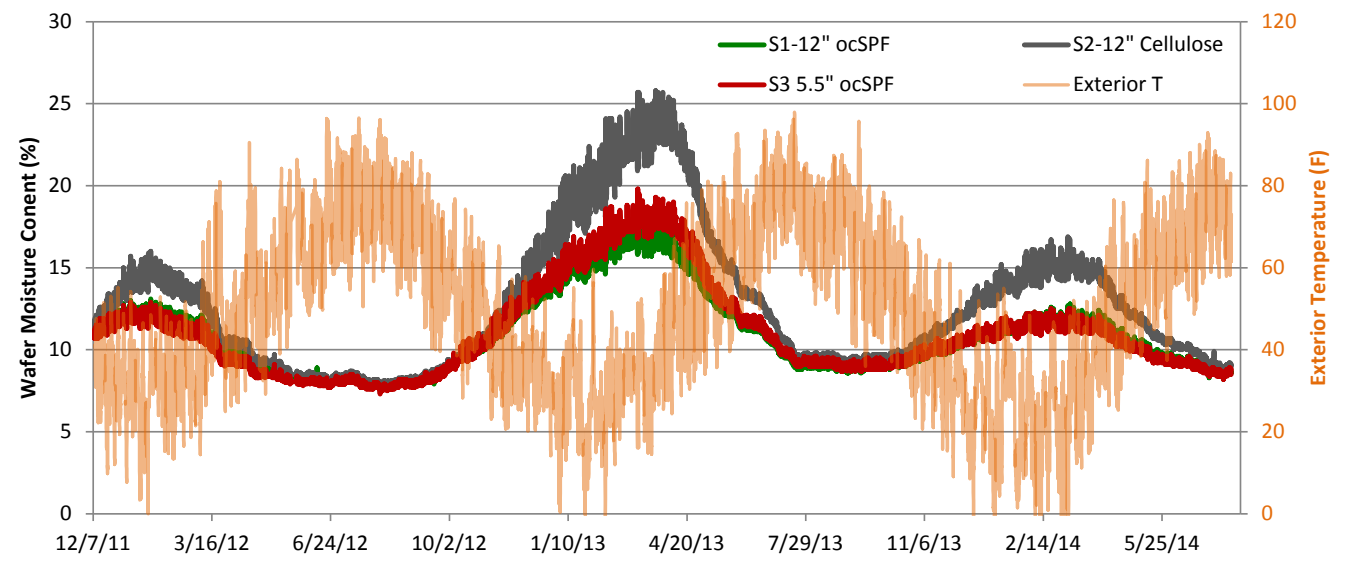

Figure 32. South-facing wall exterior framing MCs, with exterior temperature for reference

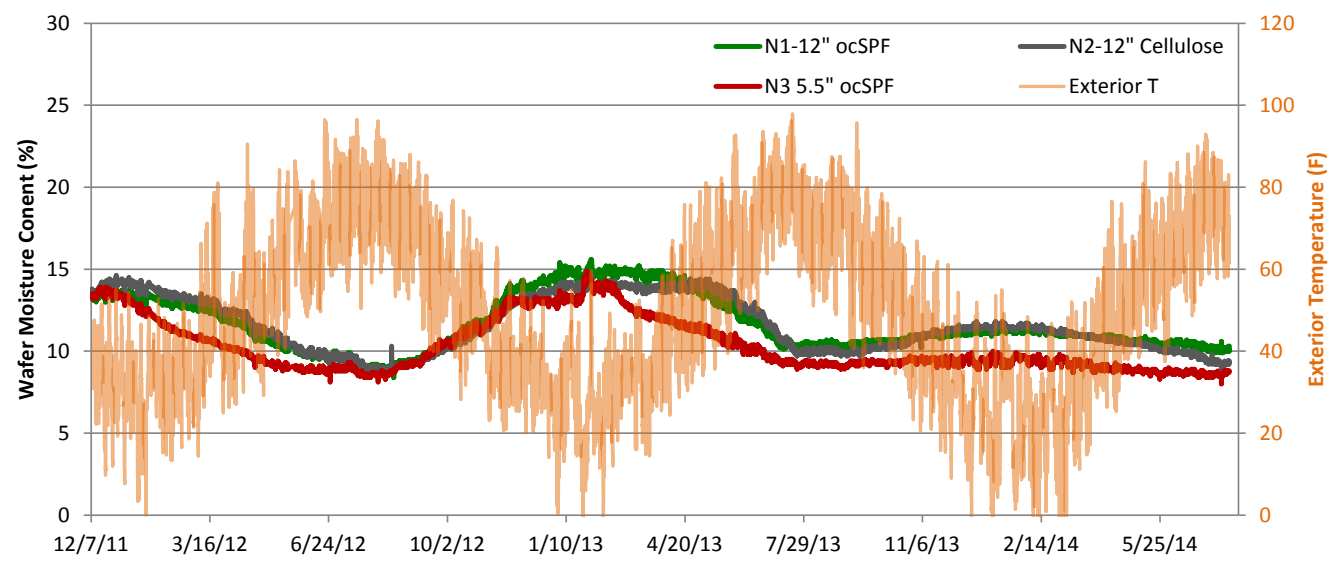

Figure 33. North-facing wall interior framing MCs, with exterior temperature for reference 


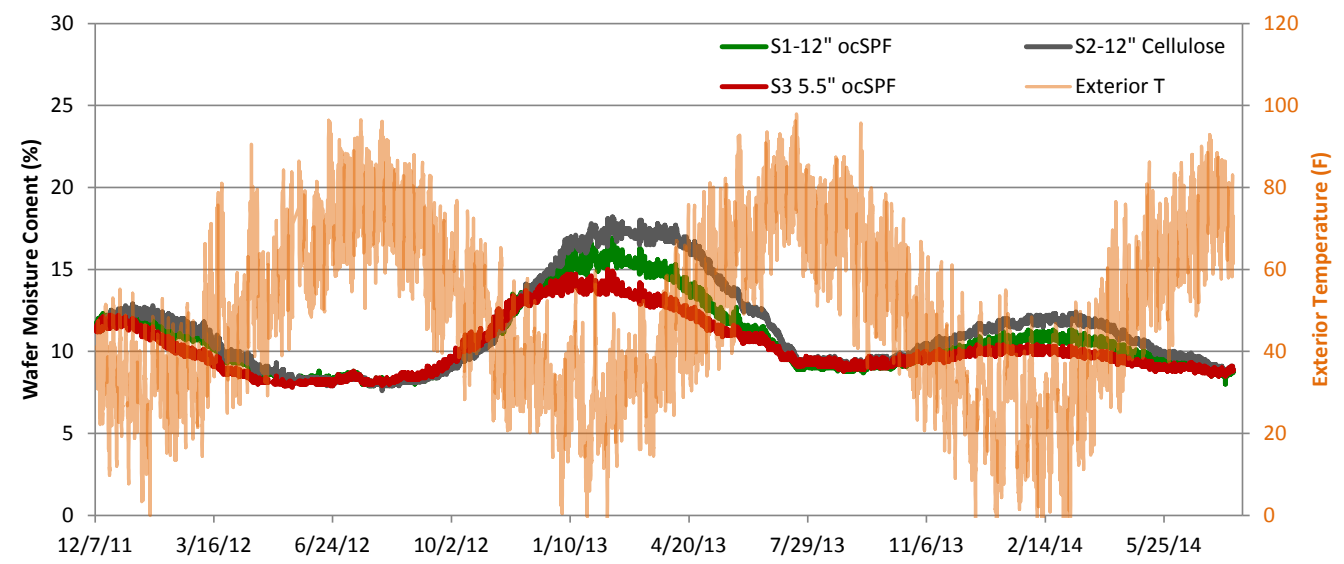

Figure 34. South-facing wall exterior framing MCs, with exterior temperature for reference

The inboard framing MCs were markedly lower than the outboard measurements, given that this side of the framing was warmer. This was especially true for N3/S2 (5-1/2-in. ocSPF), because the interior side framing ran close to interior temperatures because of minimal insulation inboard of the stud edge.

\subsection{Sheathing Temperature Measurements}

The common explanation for the greater risks associated with double-stud walls is that the sheathing is colder, because of the increase in insulation. The data were examined in more detail to determine the magnitude and significance of the temperature difference.

An infrared image at mild outdoor temperatures $\left(50^{\circ} \mathrm{F}\left[10^{\circ} \mathrm{C}\right]\right.$, overcast conditions/little direct solar gain) shows no clear difference between the three test walls (Figure 35). Of course, greater surface temperature differences would be expected in colder conditions. In addition, vinyl siding is a ventilated cladding, and would tend to "mask" sheathing temperature differences.

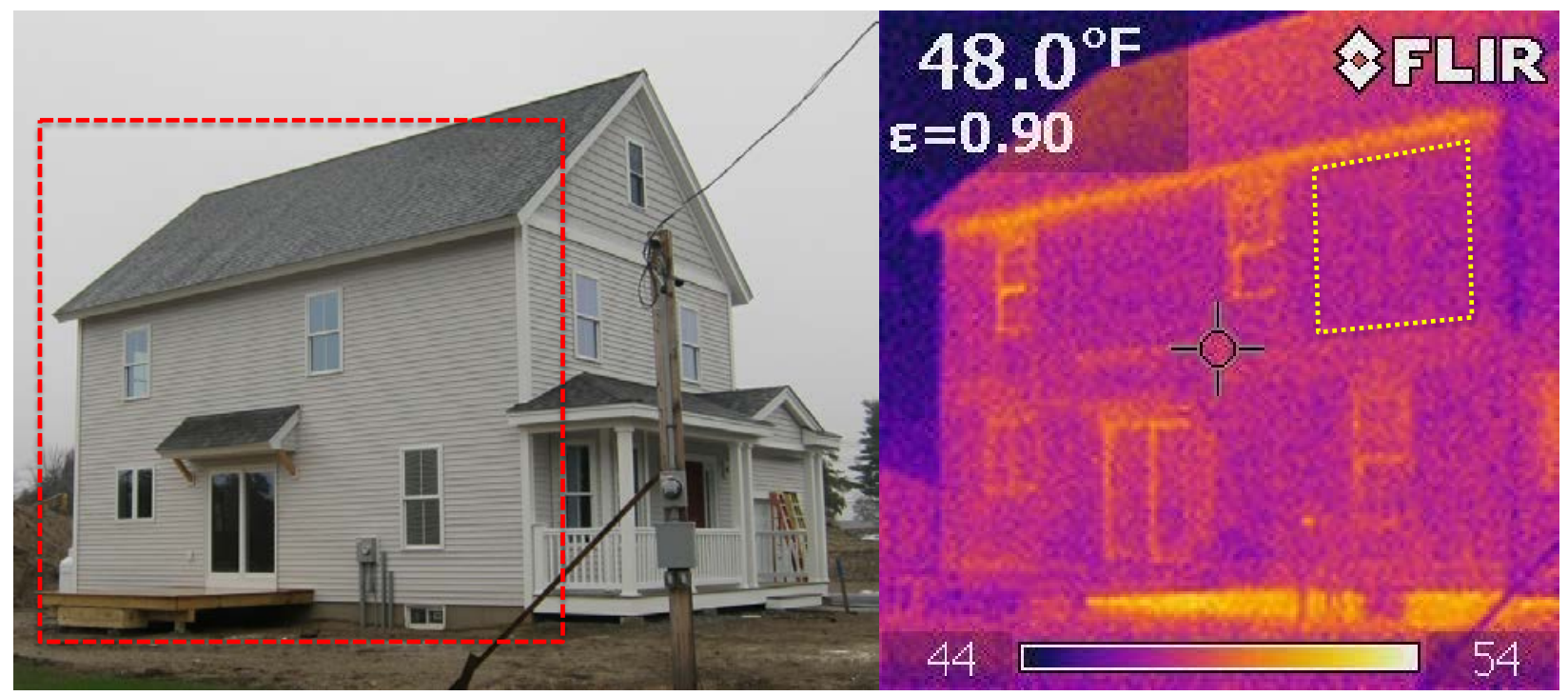

Figure 35 . South-facing wall infrared image; $50^{\circ} \mathrm{F}\left(10^{\circ} \mathrm{C}\right)$ outdoor conditions 
A simple steady-state analysis of the temperature drop through a double-stud wall assembly can be used to calculate the temperature at the interior side of the sheathing. Assuming an outdoor temperature of $7^{\circ} \mathrm{F}$, the temperature difference between 12-in. ocSPF and 5-1/2-in. ocSPF would be $0.8^{\circ} \mathrm{F}\left(0.4^{\circ} \mathrm{C}\right)$. This is a very small difference, and would be seen only under extreme conditions. The data were checked to verify this prediction.

The mid-height sheathing temperature for the north side wall for two winter months (December 2013-January 2014) is shown in Figure 36, with exterior temperature for reference. It is very difficult to differentiate between the walls, so a 2-week period in January was plotted at higher resolution (Figure 37).

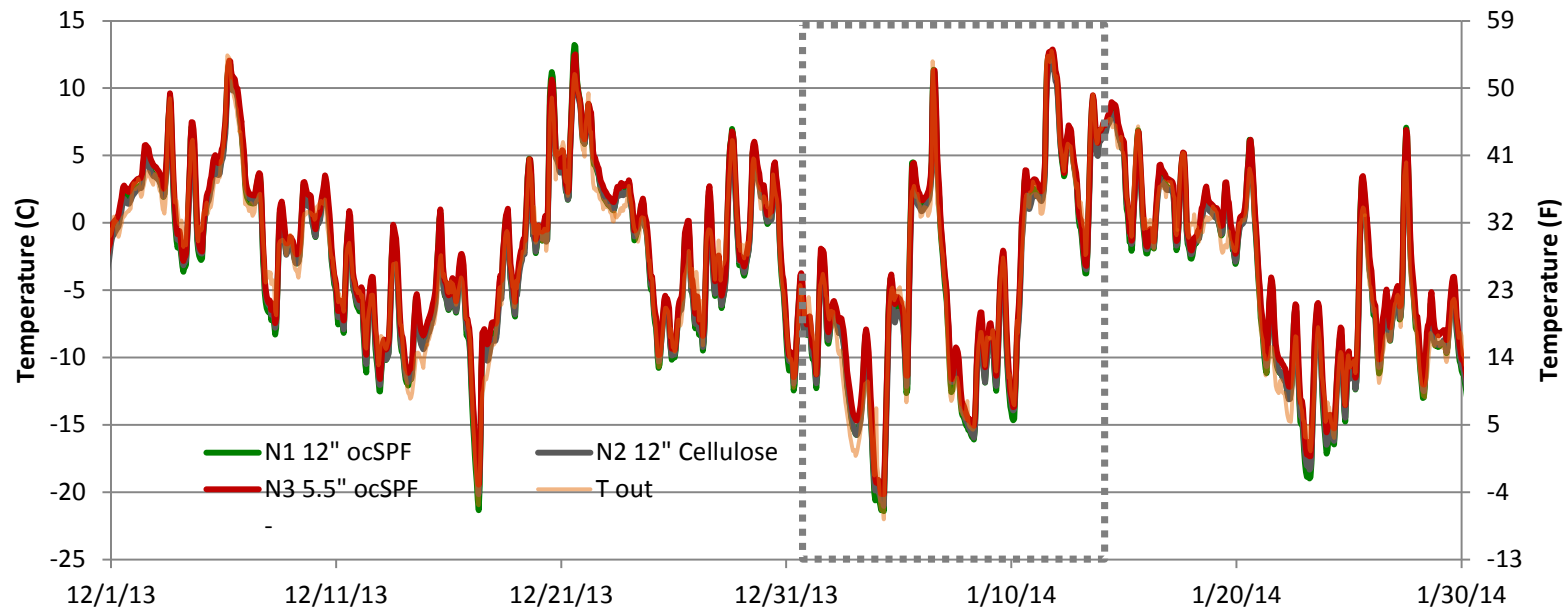

Figure 36. North-facing wall sheathing temperatures, mid-height (December-January)

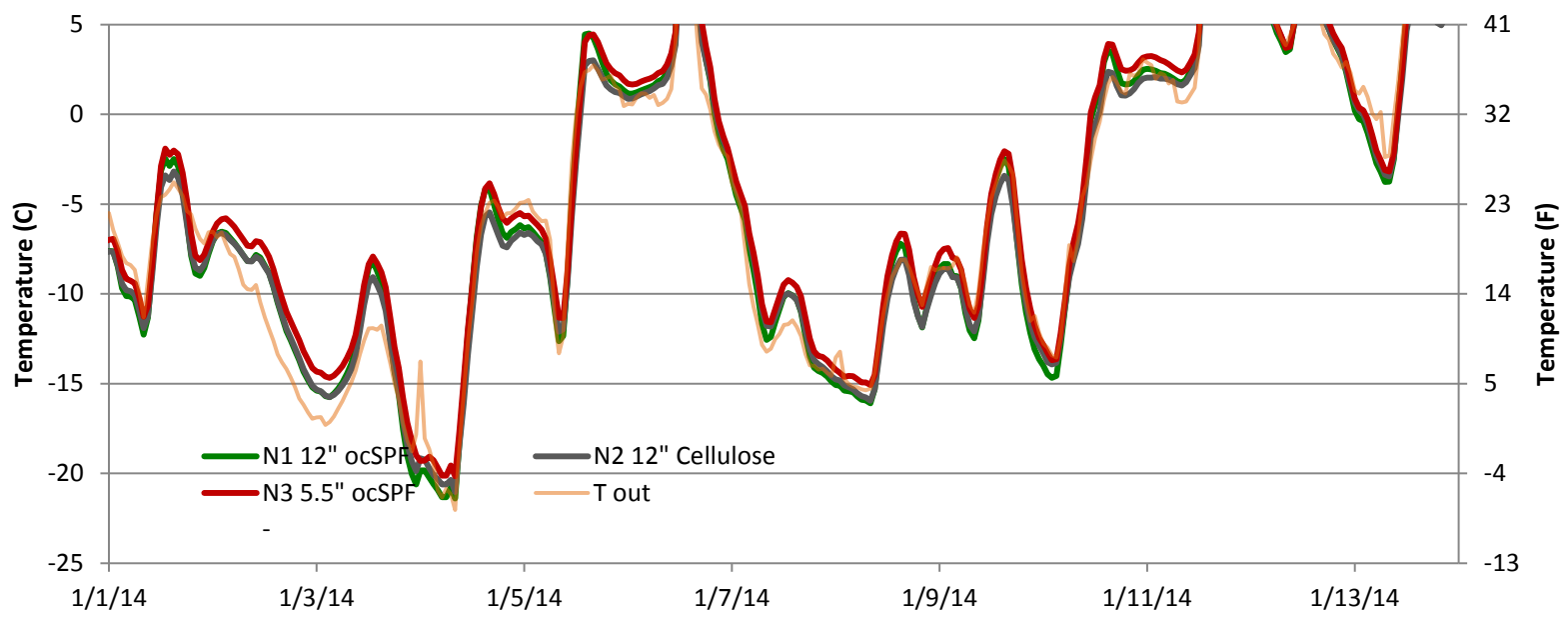

Figure 37. North-facing wall sheathing temperatures, mid-height (January 2 weeks)

The plot appears to show that the 5-1/2-in. ocSPF wall (N3) has slightly higher sheathing temperatures, but the difference is very small - the largest discernable differences are generally about $1^{\circ} \mathrm{F}\left(0.5^{\circ} \mathrm{C}\right)$ or less. 
A larger data set can be examined by plotting the sheathing temperature against outdoor temperature, as shown in Figure 38 for the north-facing middle and upper sheathing sensors. Sheathing that is warmer or colder, on average, should show a pattern of being above or below the $1: 1$ diagonal parity line.
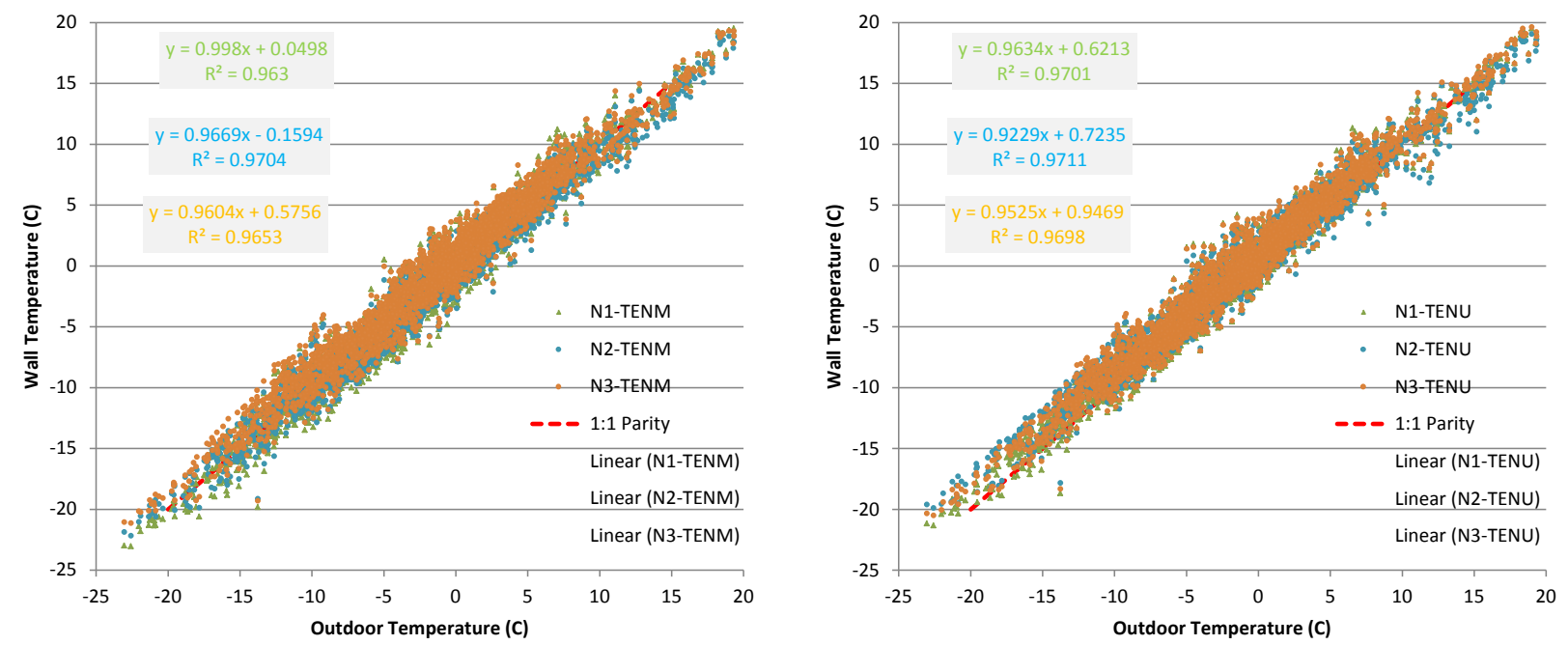

Figure 38. Sheathing temperature versus outdoor temperature, middle and upper north sheathing

However, it is difficult to visualize any clear patterns in the data. A further step was taken of plotting the trendlines for the data (assuming a linear relationship) and calculating sheathing temperature as a function of outdoor temperature. The calculations show inconsistent results, with N2/5-1/2-in. ocSPF not always coldest.

Instead of sheathing temperature being the key metric of importance, the relative amounts of heat/drying energy might be the key factor (per Lstiburek 2008). Doubling the insulation thickness will halve the amount of heat flowing from the interior during the winter, through the sheathing. 


\section{Wall Disassembly and Conditions}

At the conclusion of any enclosure monitoring experiment, a useful step is to open the test assemblies and examine the conditions. It is instructive to understand how the monitored data relate to actual damage or material durability. Therefore, the test walls were temporarily disassembled at the end of the experiment (July 2014). The south wall is shown in Figure 39.
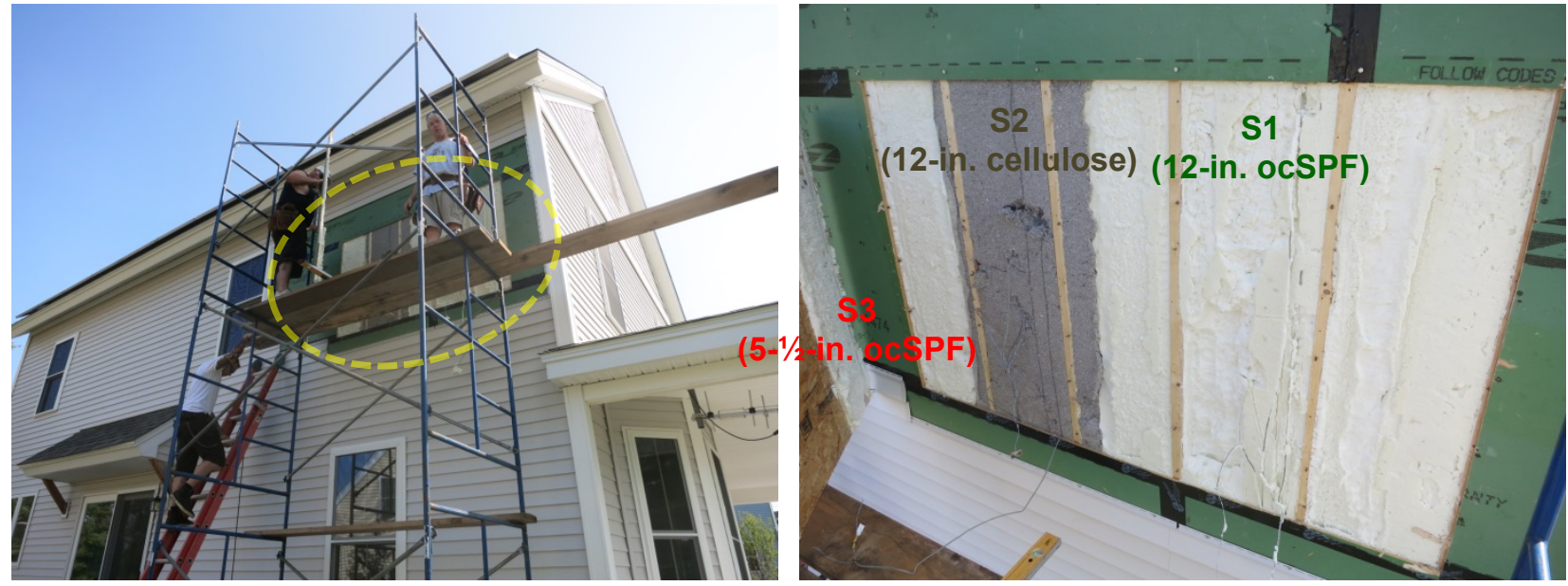

Figure 39. South-facing wall disassembly, showing test bay cavities

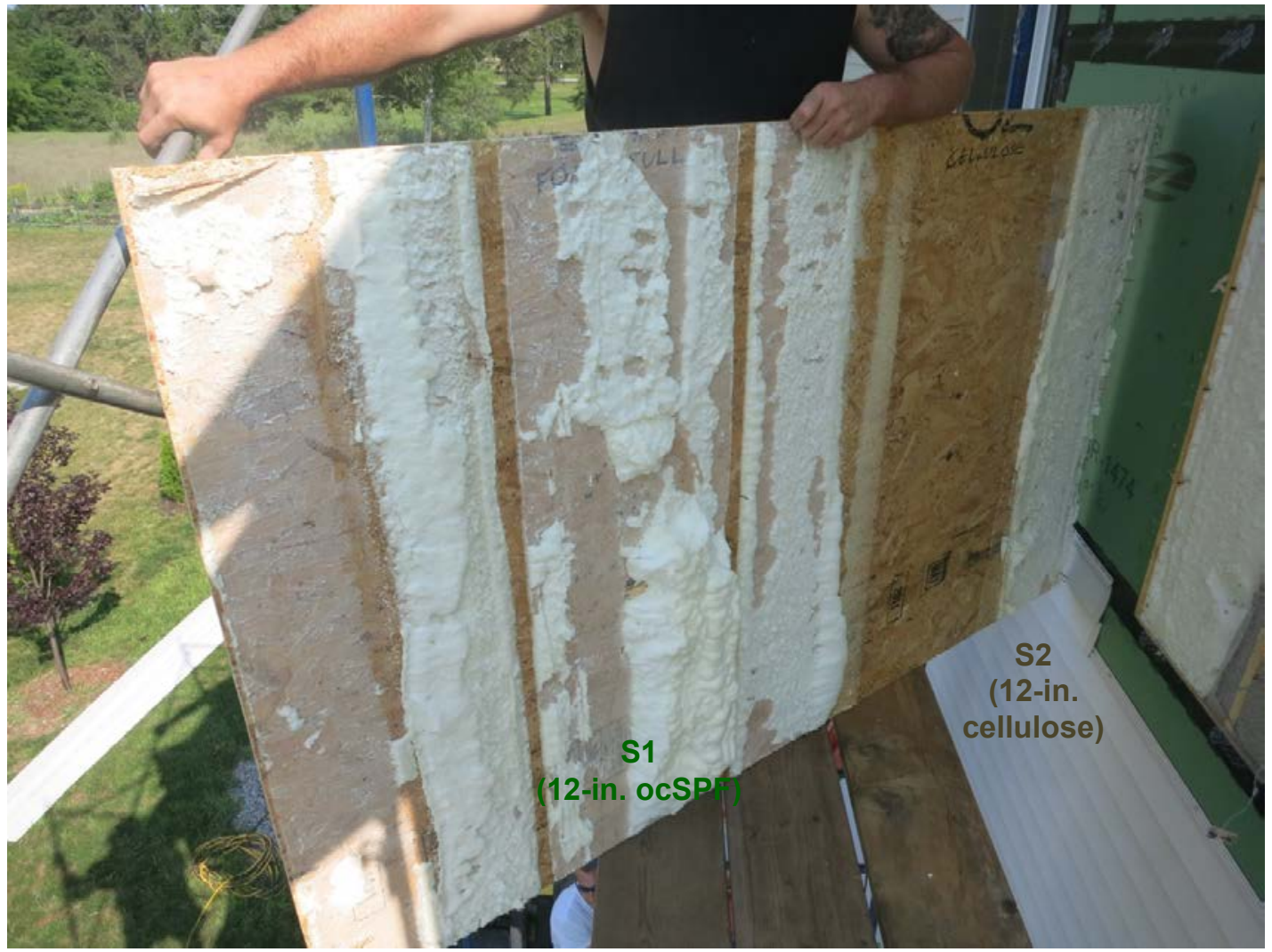

Figure 40. South-facing wall sheathing conditions 
The sheathing was removed, taking some adhered ocSPF with it (causing the visible "divots" in the stud bay foam). The condition of the sheathing was surprisingly good, considering that all measurements indicated liquid water condensation for extended times during the winter, especially in the cellulose wall. There was no visible mold growth, staining, water rundown evidence, or delamination at the sheathing (Figure 40 and Figure 41, left) or at the framing (Figure 41, right). The minor evidence of damage included a slight grain raise at the cellulose wall (compared to the ocSPF walls), and minor rusting of nails and staples. The dense-pack cellulose all remained in place during the disassembly; no evidence of settling was seen at the opening. There was no sign of "caking" of the cellulose, which is regarded as an indication of dried moisture accumulation (Rose and McCaa 1998; Derome 2005). All materials were dry to the touch; no handheld MC measurements were taken, given that all sensors were at dry conditions.
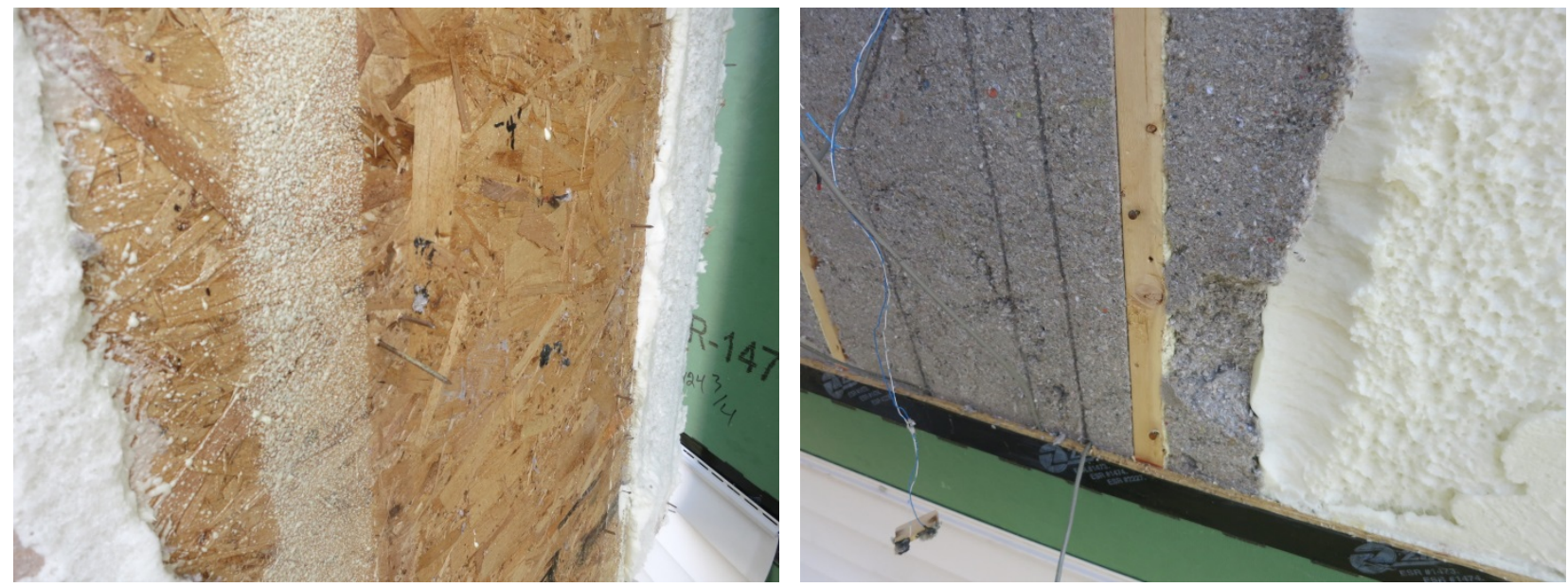

Figure 41. Sheathing and framing conditions at south-facing walls

The north-facing walls were similarly disassembled (Figure 42); these walls were of particular interest, given that monitoring indicated that moisture accumulation was more severe at this orientation.
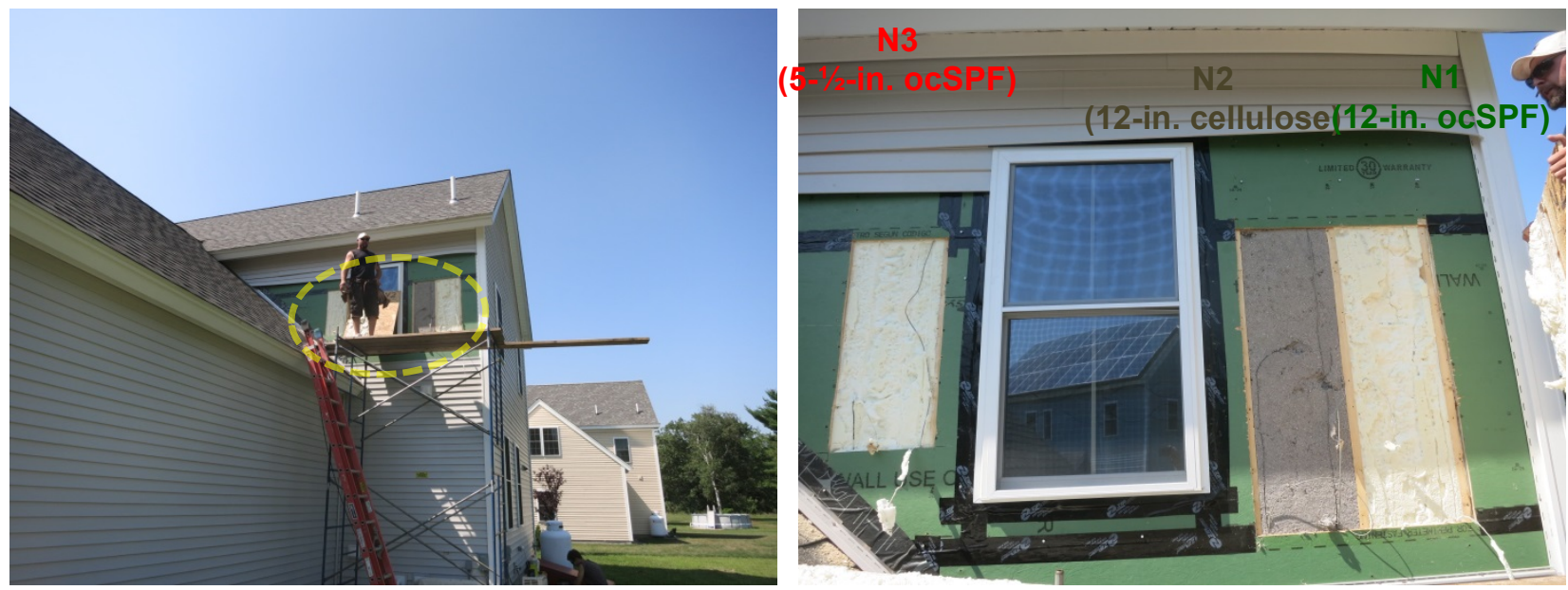

Figure 42. North-facing wall disassembly, showing test bay cavities 
The sheathing, framing, and insulation conditions were again surprisingly intact. Similar to the south wall, no signs of moisture damage or mold were visible; there was a slight grain raise on the cellulose sheathing, as well as some rusted fasteners. All of these observations are consistent with liquid water condensation that dried before significant damage could occur.

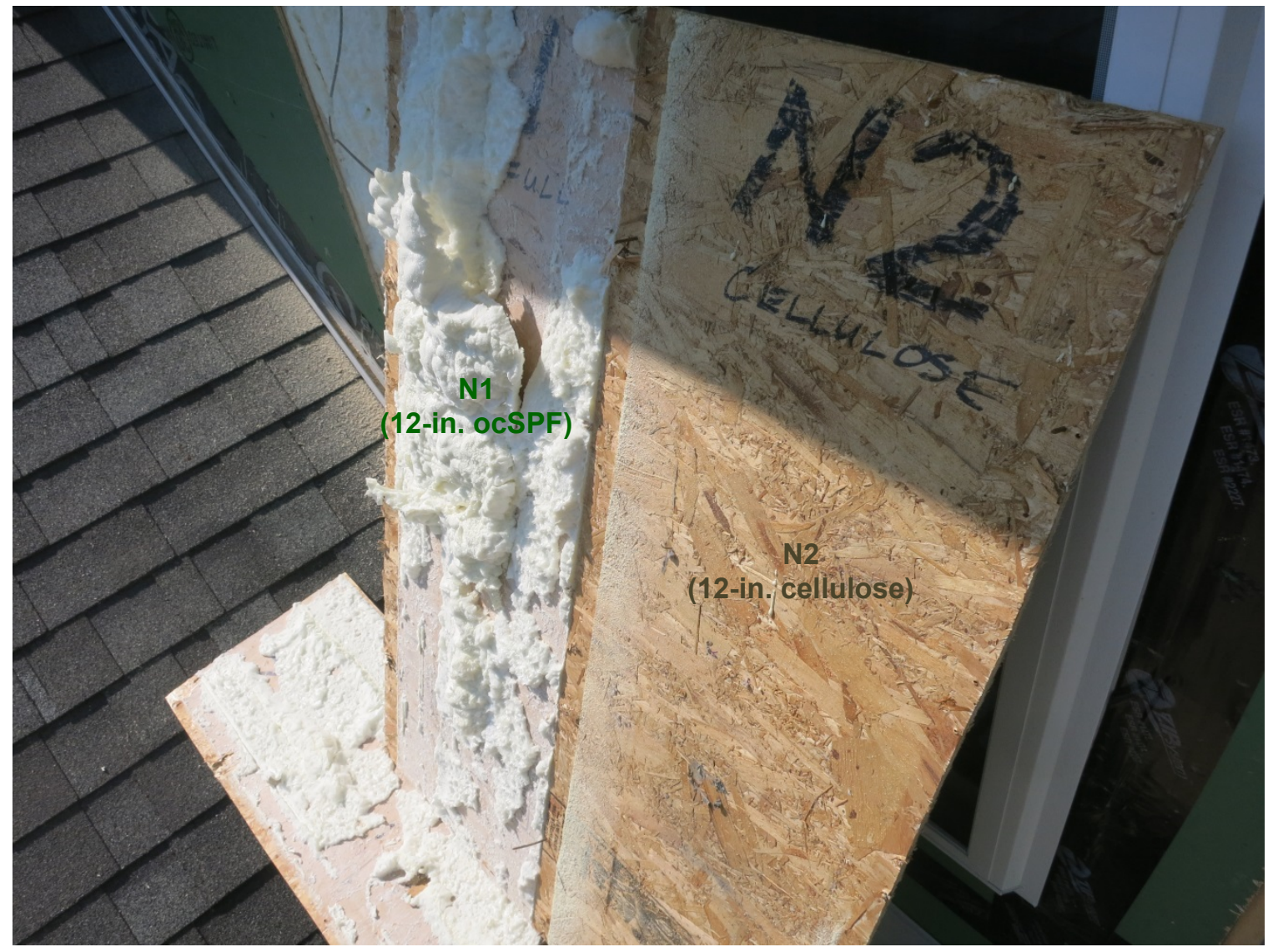

Figure 43. South-facing wall sheathing conditions (12-in. ocSPF/N1 and cellulose/N2)
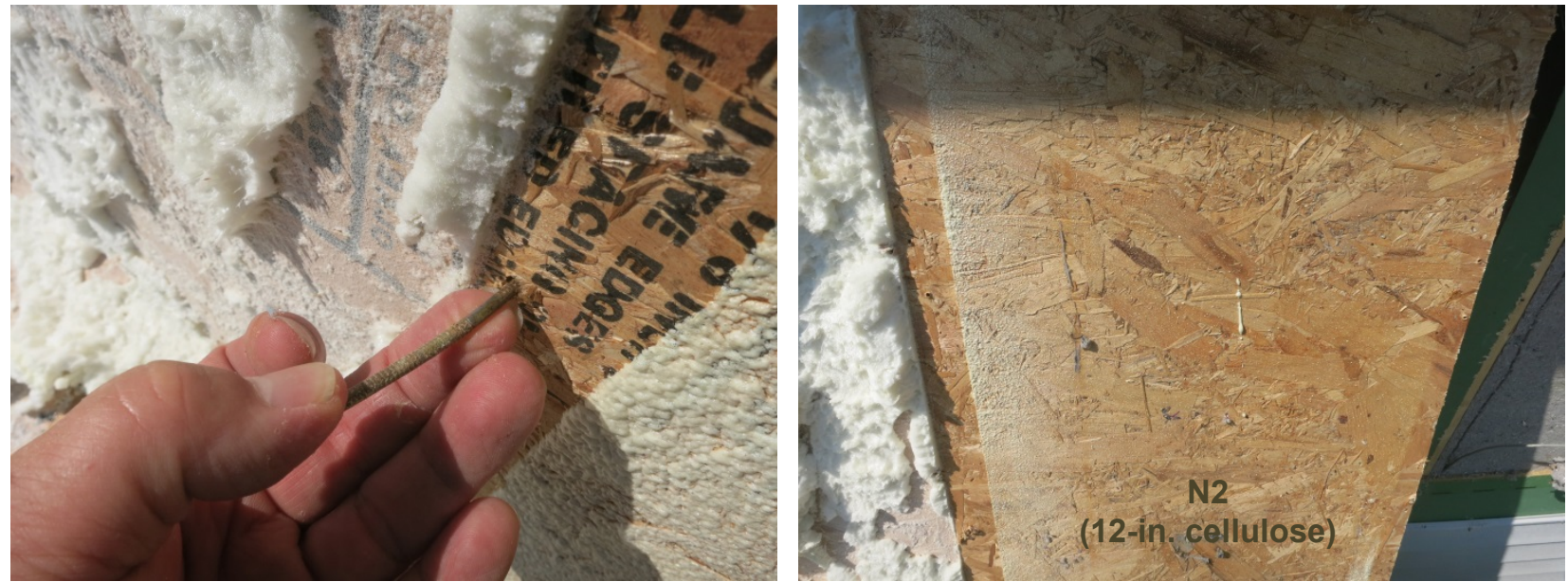

Figure 44. North-facing wall conditions at fastener and sheathing at cellulose bay (N2) 
No evidence was seen of voids or "pockets" in the ocSPF stud bay insulation, which is has been observed at other installations.
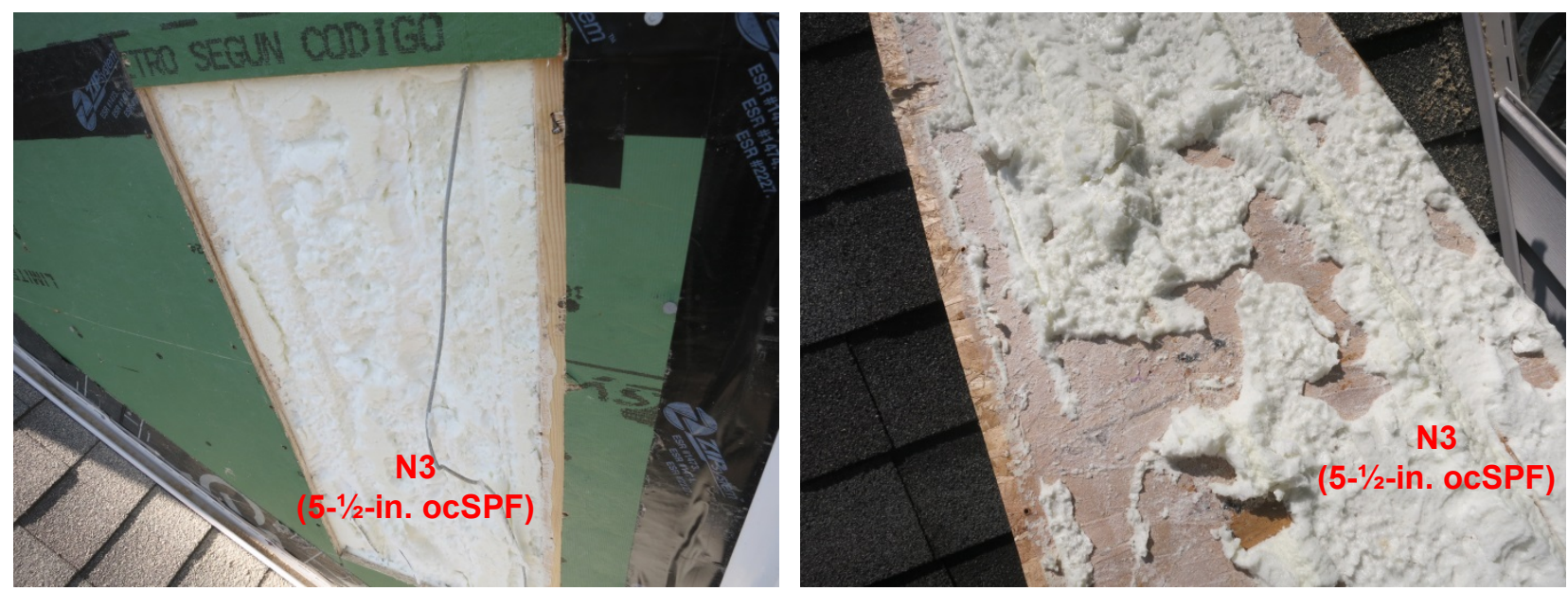

Figure 45. Stud bay cavity and sheathing conditions at 5-1/2-in. ocSPF north-facing wall (N3)

The $\mathrm{MC}$ wafers at the insulation-sheathing interface were also examined during disassembly. Some wafers had slight discoloration consistent with wetting, but no clear signs of mold growth.

No specific mold testing (i.e., tape lifts or air sampling) was conducted during this disassembly; the surfaces were examined with visual inspection only (without a hand lens).

Following this disassembly, the walls were reassembled. The existing sheathing was reused, given the lack of visible damage. 


\section{Analysis and Interpretation}

\subsection{Data Overview}

Given the various measurements and multiple wintertime conditions, the key MCs are summarized in Table 4. Results are provided for the three winters: 2011-2012 (very low interior RH, mild exterior temperatures), 2012-2013 (extremely high interior RH, normal exterior temperatures), and 2013-2014 (normal/low interior RH, and cold exterior temperatures).

The results are given for the six walls, in terms of wintertime peak MC for the sheathing, wafer, and outer sheathing. Sheathing and framing MCs exceeding 20\% are highlighted in red: as discussed below, this is often given as a "safe" level, below which mold growth is impossible. Wafer MCs over 30\% (100\% RH-equivalent) are highlighted in green, which show indications of condensation at the sheathing-insulation interface.

Table 4. Peak Wintertime MCs for Sheathing, Wafer and Outer Framing (Three Winters)

\begin{tabular}{|c|c|c|c|c|}
\hline Wall & Measurement & $\begin{array}{c}\text { Winter 2011-2012 } \\
\text { (low interior RH, } \\
\text { mild exterior T) }\end{array}$ & $\begin{array}{l}\text { Winter 2012-2013 } \\
\text { (high interior RH, } \\
\text { normal exterior T) }\end{array}$ & $\begin{array}{c}\text { Winter 2013-2014 } \\
\text { (low interior RH, } \\
\text { cold exterior T) }\end{array}$ \\
\hline \multirow{3}{*}{$\begin{array}{l}\text { N1, 12-in. } \\
\text { ocSPF }\end{array}$} & Sheathing & $12 \%-15 \%$ & $20 \%-26 \%$ & $15 \%-18 \%$ \\
\hline & Wafer & $25 \%$ & $38 \%$ & $28 \%$ \\
\hline & Outer framing & $15 \%$ & $18 \%$ & $13 \%$ \\
\hline \multirow{3}{*}{$\begin{array}{l}\mathrm{N} 2,12 \text {-in. } \\
\text { cellulose }\end{array}$} & Sheathing & $20 \%-28 \%$ & $25 \%-33 \%$ & $15 \%-23 \%$ \\
\hline & Wafer & $38 \%$ & $50 \%$ & $37 \%$ \\
\hline & Outer framing & $18 \%$ & $26 \%$ & $17 \%$ \\
\hline \multirow{3}{*}{$\begin{array}{l}N 3,5-1 / 2^{-} \\
\text {in. ocSPF }\end{array}$} & Sheathing & $15 \%-20 \%$ & $24 \%-26 \%$ & $15 \%-16 \%$ \\
\hline & Wafer & $22 \%$ & $30 \%$ & $18 \%$ \\
\hline & Outer framing & $16 \%$ & $18 \%$ & $11 \%$ \\
\hline \multirow{3}{*}{$\begin{array}{l}\text { S1, 12-in. } \\
\text { ocSPF }\end{array}$} & Sheathing & $13 \%-14 \%$ & $16 \%-\mathbf{2 0 \%}$ & $12 \%-15 \%$ \\
\hline & Wafer & $18 \%$ & $25 \%$ & $19 \%$ \\
\hline & Outer framing & $14 \%$ & $18 \%$ & $13 \%$ \\
\hline \multirow{3}{*}{$\begin{array}{l}\mathrm{S} 2,12 \text {-in. } \\
\text { cellulose }\end{array}$} & Sheathing & $14 \%-16 \%$ & $17 \%-\mathbf{3 0} \%$ & $12 \%-19 \%$ \\
\hline & Wafer & $31 \%$ & $50 \%$ & $36 \%$ \\
\hline & Outer framing & $16 \%$ & $26 \%$ & $17 \%$ \\
\hline \multirow{3}{*}{$\begin{array}{l}\text { S3, 5-1/2- } \\
\text { in. ocSPF }\end{array}$} & Sheathing & $13 \%-15 \%$ & $19 \%-\mathbf{2 4 \%}$ & $12 \%-15 \%$ \\
\hline & Wafer & $20 \%$ & $25 \%$ & $18 \%$ \\
\hline & Outer framing & $13 \%$ & $20 \%$ & $12 \%$ \\
\hline
\end{tabular}

Sheathing and framing MCs $>\mathbf{2 0} \%$ highlighted (mold growth possible)

Wafer MCs $>30 \%$ highlighted (over $100 \%$ RH-equivalent)

The table summarizes the previous findings: north walls have worse (wetter) performance than south walls, the second (high RH) winter resulted in extremely challenging conditions and high $\mathrm{MCs}$, and the cellulose wall showed consistently higher MCs than either ocSPF wall. In fact, the cellulose wall showed liquid water condensation conditions in all three winters, on both orientations. But as discussed above, every summer, MCs dried down into the safe range in all six walls. 
The sheathing MCs are shown as a range, given the three MC measurements (low/middle/high) at each test wall. This range of MCs might be an accurate reflection of higher/lower spatial MCs. However, it might also reflect differences caused by the composite nature of OSB: OSB wafers are typically manufactured from a mixture of available wood species, which has an effect on the electrical resistance-MC response. Also, a set of moisture pins that spans two discontinuous OSB wafers might have a different electrical response than those driven into a single wafer.

Hygrothermal models are often fine-tuned to match measured data; the fact that there are significant variations among one-dimensionally identical wall sections calls into question the value of extensive model tuning.

\subsection{Assembly Vapor Permeability Properties}

As shown above, the ocSPF walls (both 12-in. and 5-1/2-in.) had lower MCs than the cellulose (12-in.) wall. These materials are both regarded as "vapor open," which allow drying to the interior. All of the walls have a relatively vapor open Class III vapor retarder (latex paint on gypsum board) as the interior vapor control layer.

One difference between these insulation materials is that ocSPF thicker than a certain range (e.g., $4-1 / 2$ in. $)$ meets the requirements for an air barrier material $\left(0.004 \mathrm{cfm} / \mathrm{ft}^{2}\right.$ at $0.3 \mathrm{in}$. w.c. or 0.02 $\mathrm{L} /\left(\mathrm{s} \cdot \mathrm{m}^{2}\right)$ at $75 \mathrm{~Pa}$, per Lstiburek 2005). In contrast, cellulose (including dense-pack cellulose) does not meet the air barrier material requirement, despite providing substantial air leakage reductions in retrofit assemblies (Lstiburek 2010). It is possible that interior-source air leakage into the wall cavity may be playing a role in this difference; however, given the measured airtightness of the house (1.1 ACH 50), the magnitude of the air leakage is likely small.

Another explanation can be found in the vapor permeability of the assembly inboard of the condensing surface (OSB sheathing). Although ocSPF is generally thought of as vapor permeable, at the thickness applied at the double-stud wall here, there is significant vapor resistance. Table 1 shows the vapor permeability of the insulation layer alone, as well as in series with a $10 \mathrm{perm} / 575 \mathrm{ng} /\left(\mathrm{Pa} \cdot \mathrm{s} \cdot \mathrm{m}^{2}\right)$ vapor retarder (Class III vapor retarder), or latex paint on gypsum board.

Table 5. Vapor Permeability of Insulation and Assemblies

\begin{tabular}{c|c|c|c}
\hline Wall ID & Insulation Material & $\begin{array}{c}\text { Vapor Permeability } \\
\text { (Insulation Only) }\end{array}$ & $\begin{array}{c}\text { Vapor Permeability } \\
\text { (Add 10 Perm Class III } \\
\text { Vapor Retarder) }\end{array}$ \\
\hline N1/S1 & 12-in. 0.5 PCF foam & $1.8-2.5$ perms & $1.5-2.0$ perms \\
N2/S2 & 12-in. cellulose & $7.0-10$ perms & $4.0-5.0$ perms \\
N3/S3 & 5-1/2-in. 0.5 PCF foam & $4.0-5.5$ perms & $2.9-3.5$ perms \\
\hline
\end{tabular}

It appears that at the thicknesses applied here, the ocSPF used here provides reasonable vapor control from interior-sourced moisture. Note that the spray foam values are taken from manufacturer's data, so they are not identical to the ASHRAE value stated previously (7.3 perms for 12-in. insulation, both wet and dry cup; ASHRAE 2009a, compared to 1.8-2.5 perms).

The vapor permeance of the latex painted and primed gypsum was not measured; however, measurements at previous sites showed results in the 7-12 perm (dry cup) range, consistent with 
the value used for a Class III vapor retarder (10 perm). Schumacher and Reeves (2007) reported permeance measurements of 8 perms for drywall with two coats of latex paint, and 30 perms for drywall samples finished with a knock-down coating. NAHB Research Center's (2010) testing yielded much higher permeability values, measuring 40 perms for drywall with two coats of latex paint (dry cup).

For reference, the use of a Class III vapor retarder is allowed by code in conventional construction, assuming a vented cladding (ICC 2009). In zone 5, allowable assemblies include vented cladding (such as vinyl siding) over OSB, plywood, fiberboard, or gypsum sheathing. However, a double-stud wall has different behavior than conventional $(2 \times 4$ or $2 \times 6)$ construction.

\subsection{Mold Risks, Moisture Content, and Condensation}

Moisture-related failures of building enclosures are typically defined by risks of mold growth or growth of decay fungi on vulnerable substrates. Traditional guidance is to keep wood MC below 20\%; decay fungi are inhibited below this level (Carll and Highley 1999), with optimum growth occurring in the $25 \%-30 \% \mathrm{MC}$ range. Decay fungi become active at MC levels above $28 \%$ (Straube and Burnett 2005).

As shown by the data summary (Table 4), all OSB wall sheathings exceeded $20 \% \mathrm{MC}$ in winter 2012-2013 (second winter, high humidity); the cellulose walls (N2/S2) had peaks exceeding $30 \%$. These results show that all of the walls, especially the cellulose wall, are at risk of failurebased on monitored data - under those loading conditions.

However, the MCs should be interpreted with temperatures in mind. Biological activity is inhibited at low and high temperatures, so high MCs in midwinter pose less risk than in warmer seasons. Ideal temperatures vary by mold species, but typically, growth is most rapid between $68^{\circ}-95^{\circ} \mathrm{F}\left(20^{\circ}-35^{\circ} \mathrm{C}\right)$, and stops below $41^{\circ} \mathrm{F}\left(5^{\circ} \mathrm{C}\right)$ and above $122^{\circ} \mathrm{F}\left(50^{\circ} \mathrm{C}\right)$. Sustained high MCs at moderate temperatures pose the greatest durability risks. In the collected data, all walls dried to MCs well within the safe range during the summer: the question is whether MCs fell sufficiently before temperatures warmed. This temperature-moisture risk assessment is covered in a more quantitative manner in the following sections.

In addition, the wafer sensors showed that sheathing condensation was occurring at the sheathing-insulation interface in all walls during the second winter, and in the cellulose wall in the third winter. Although high RH conditions are associated with mold and decay, liquid water (i.e., condensation) greatly accelerates degradation of common building materials (Doll 2002). Therefore, the presence or absence of condensation might be considered as another failure criterion.

\subsection{ASHRAE Standard 160 Analysis}

ASHRAE Standard 160 (ASHRAE 2009b) provides guidance on moisture analysis for building envelope design, including the moisture performance evaluation criteria. The failure criteria (defined as the risk of mold growth) were redefined in addendum (a) (ASHRAE 2011), as follows: 
6.1 Conditions Necessary to Minimize Mold Growth. In order to minimize problems associated with mold growth on the surfaces of components of building envelope assemblies, condition shall be met: a 30-day running average surface $\mathrm{RH}<80 \%$ when the 30-day running average surface temperature is between $5^{\circ} \mathrm{C}$ $\left(41^{\circ} \mathrm{F}\right)$ and $40^{\circ} \mathrm{C}\left(104^{\circ} \mathrm{F}\right)$.

Materials that are naturally resistant to mold or have been chemically treated to resist mold growth may be able to resist higher surface relative humidities and/or to resist for longer periods as specified by the manufacturer. The criteria used in the evaluation shall be stated in the report.

As noted earlier, other practitioners (Arena et al. 2013; Arena 2014) have found ASHRAE 160 criteria to be excessively stringent/conservative.

The standard is silent on evaluating failure in terms of material MCs or liquid water condensation (i.e., the results shown earlier in this report). In addition, although ASHRAE 160 refers to materials that are resistant to mold, the standard does not provide any analysis on the relative vulnerablity of materials (e.g., comparing fiberglass, cellulose, or polyurethane spray foam).

The collected data were analyzed using ASHRAE 160 criteria; the RH at the sheathinginsulation interface was calculated from measurements. The calculation used the dew point (absolute air MC) at the outermost stud bay cavity T/RH sensor (roughly $1 / 2 \mathrm{in}$. [12 mm] from the sheathing) and the measured temperature of the sheathing to calculate the interface $\mathrm{RH}$, per Straube and Burnett (2005). Thirty-day running averages were calculated for each hour, and the resulting pass/fail results tabulated. It should be noted that, in a strict intepretation of Standard 160, a single failing hour would constitute an assembly failure.

The results for the north-facing walls are plotted in Figure 46: hours that fail ASHRAE 160 are denoted by points; outdoor temperature and the sheathing temperature (30-day rolling average) are plotted for reference.

The results show that all three walls fail ASHRAE 160 requirements during all three winters, and that the cellulose wall (N2) has the worst performance according to these criteria. In addition, winter 2012-2013 (high humidity winter) has more failing hours: the cellulose wall (N2) fails ASHRAE 160 from mid-September through mid-November, and then April through late June. It is interesting to note that failures occur in the walls in fall and spring. During the winters, sheathing temperatures drop below the $41^{\circ} \mathrm{F}\left(5^{\circ} \mathrm{C}\right)$ lower limit, even though the $\mathrm{RH}$ criterion is exceeded. Overall, based on an ASHRAE 160 analysis, the walls do not dry rapidly enough to avoid problems.

A similar plot was generated for the south-facing walls (Figure 47): on this orientation, failures occurred only during the high-humidity winter (2012-2013). Again, the cellulose wall (N2) had the worst performance, with extended periods exceeding ASHRAE conditions. 


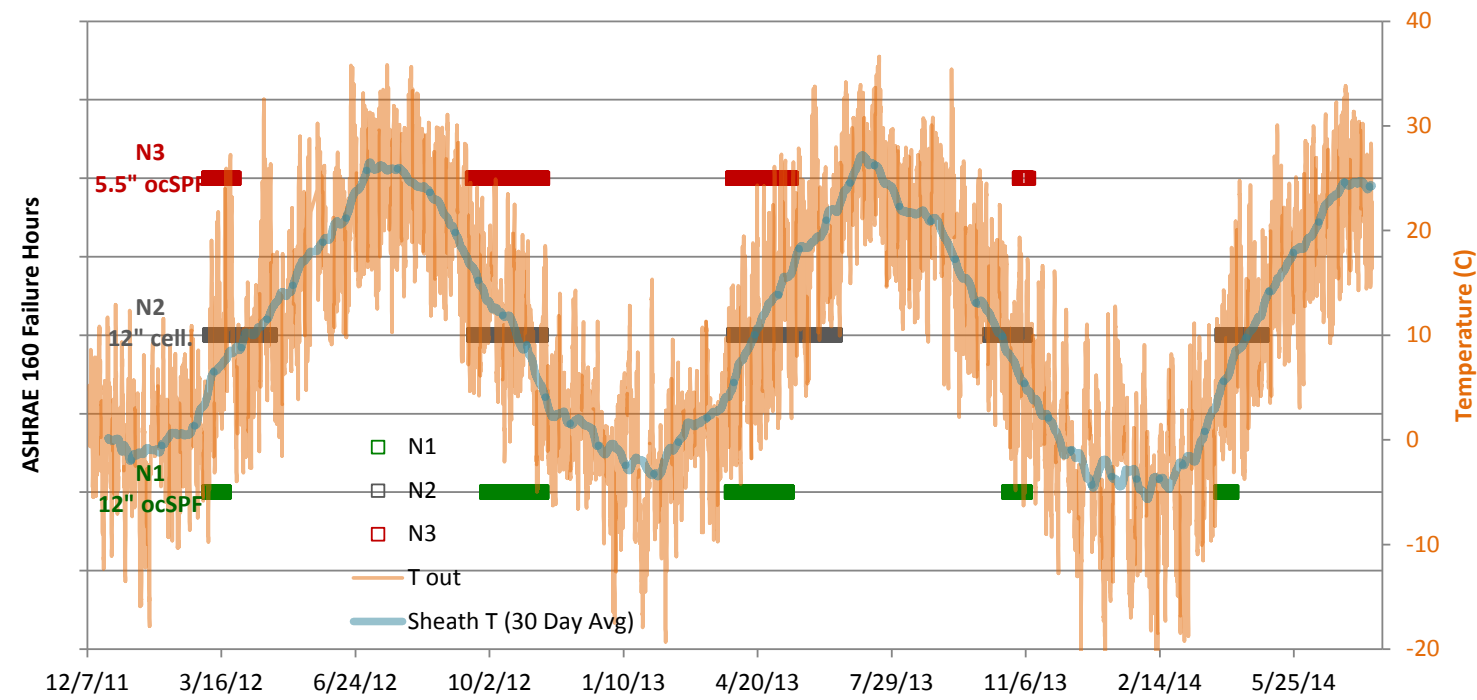

Figure 46. ASHRAE Standard 160 evaluation of north-facing walls, insulation-sheathing interface

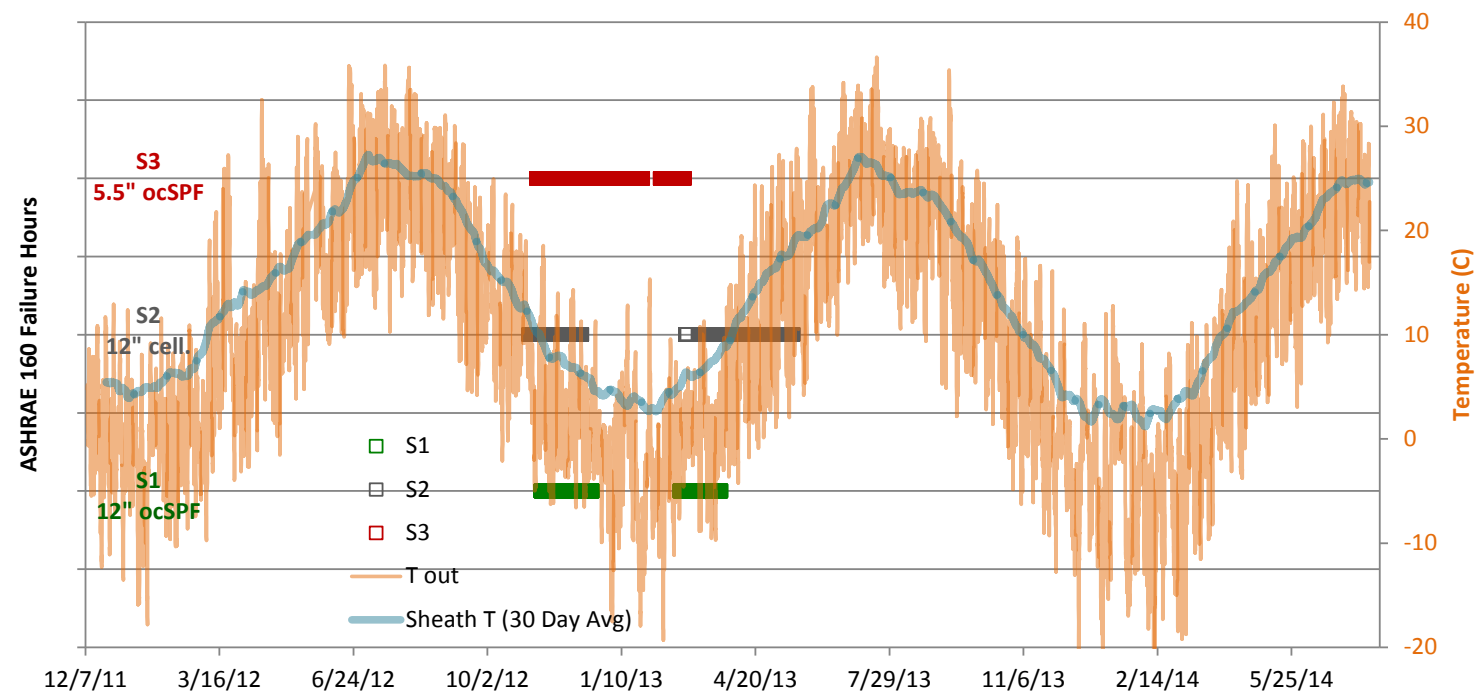

Figure 47. ASHRAE Standard 160 evaluation of south-facing walls, insulation-sheathing interface

The numbers of failing hours for the entire data set were tabulated (Table 6); they are not further broken down into individual winter seasons.

Table 6. Hours and Percent of Monitored Period Failing ASHRAE 160 Criteria

\begin{tabular}{c|c|c}
\hline Wall & \# Failure Hours & \% Time Failure \\
\hline N1, 12-in. ocSPF & 2790 & $12 \%$ \\
N2, 12-in. cellulose & 5484 & $24 \%$ \\
N3, 5-1/2-in. ocSPF & 2913 & $13 \%$ \\
S1, 12-in. ocSPF & 1657 & $7 \%$ \\
S2, 12-in. cellulose & 2646 & $12 \%$ \\
\hline S3, 5-1/2 in. ocSPF & 2273 & $10 \%$ \\
\hline
\end{tabular}


For reference, the 30-day average calculated surface $\mathrm{RH}$ for the north walls is shown in Figure 48. It demonstrates the fact that average surface humidities exeeded $80 \%$ for the entire winter, and for much of the fall and spring. However, the temperature criterion in ASHRAE 160 (temperature too low for mold growth) results in failure hours occurring in fall and spring only. It also shows the greater number of failing hours in the cellulose wall (N2), compared to the ocSPF walls (N1 and N3).

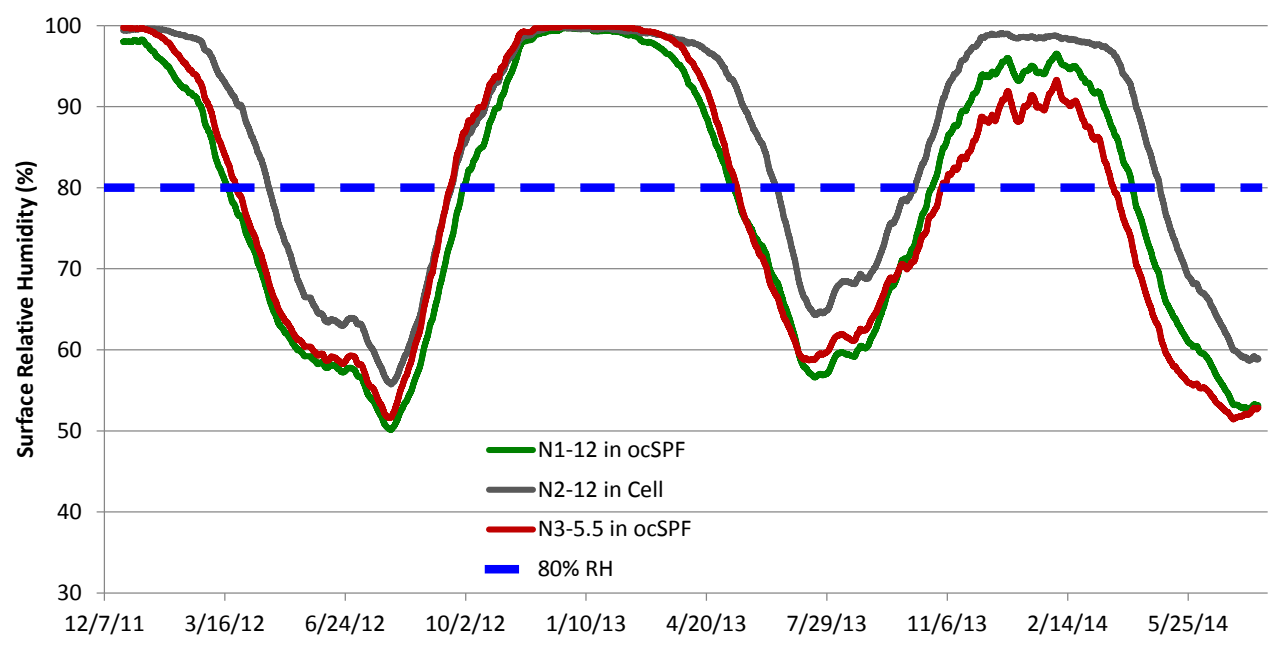

Figure 48. 30-day running average surface $\mathrm{RH}$, north walls

The diurnal cycling of surface RH levels is demonstrated in Figure 49, which plots hourly (not averaged) RH levels at the insulation-sheathing interface, for spring 2013 (March through June). The hours that fail ASHRAE 160 criteria are highlighted as well. Warmer temperatures during the daytime result in lower surface $\mathrm{RH}$ because of warmer sheathing temperatures.

It shows that there are hours when surface RH drops below 80\% that still fail ASHRAE 160 criteria. However, given that the ASHRAE 160 criteria are a 30-day running average, this fact is largely irrelevant.

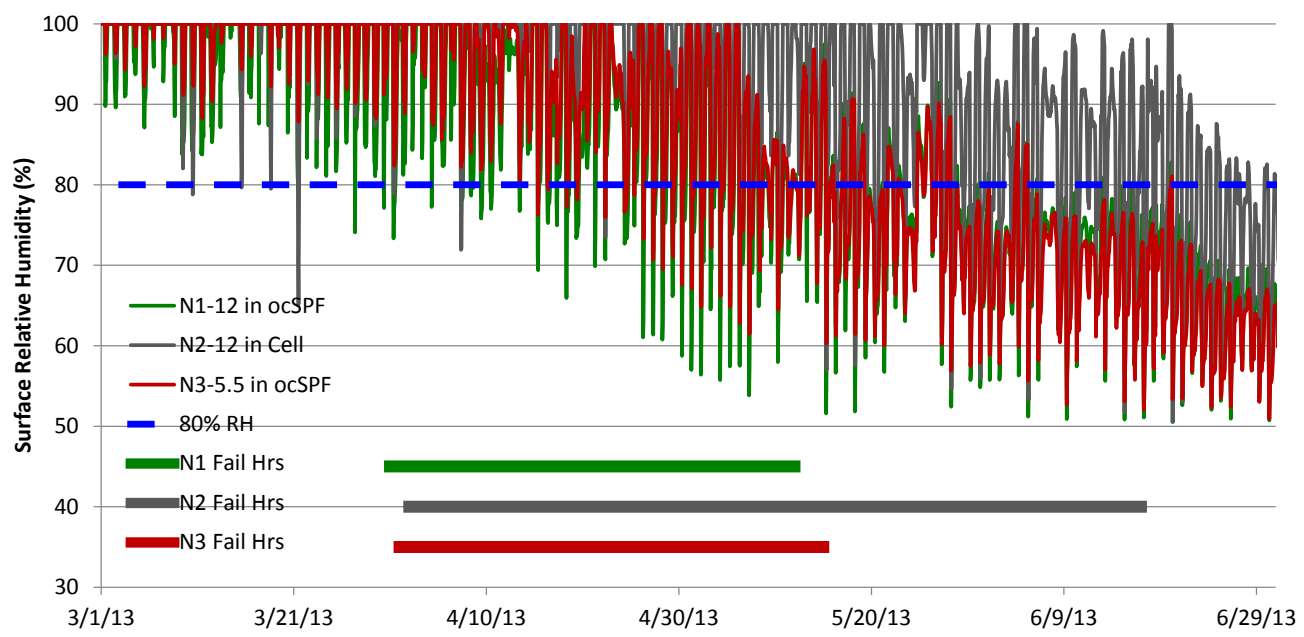

Figure 49. Hourly surface RH, north walls, with ASHRAE 160 failure hours 


\subsection{Temperature-Relative Humidity Plot (Isopleth) Analysis}

Mold risks can also be assessed with a scatter plot of T/RH; this allows quick identification of periods with sufficient moisture and temperatures to incur risk. Isopleth lines, or curves that indicate the minimum T/RH combination to support mold growth, can be plotted as limits. For instance, Viitanen and Ojanen (2007) present the plot shown in Figure 50: the lowest (critical) $\mathrm{RH}$ to sustain mold growth is a function of temperature (the isopleth line shown in green); conditions below this $\mathrm{RH}$ are too dry. Temperatures of $32^{\circ}-122^{\circ} \mathrm{F}\left(0^{\circ}-50^{\circ} \mathrm{C}\right)$ are required for growth as well. Conditions of increasing mold risk (more rapid growth) are shown by the dashed curves in purple.

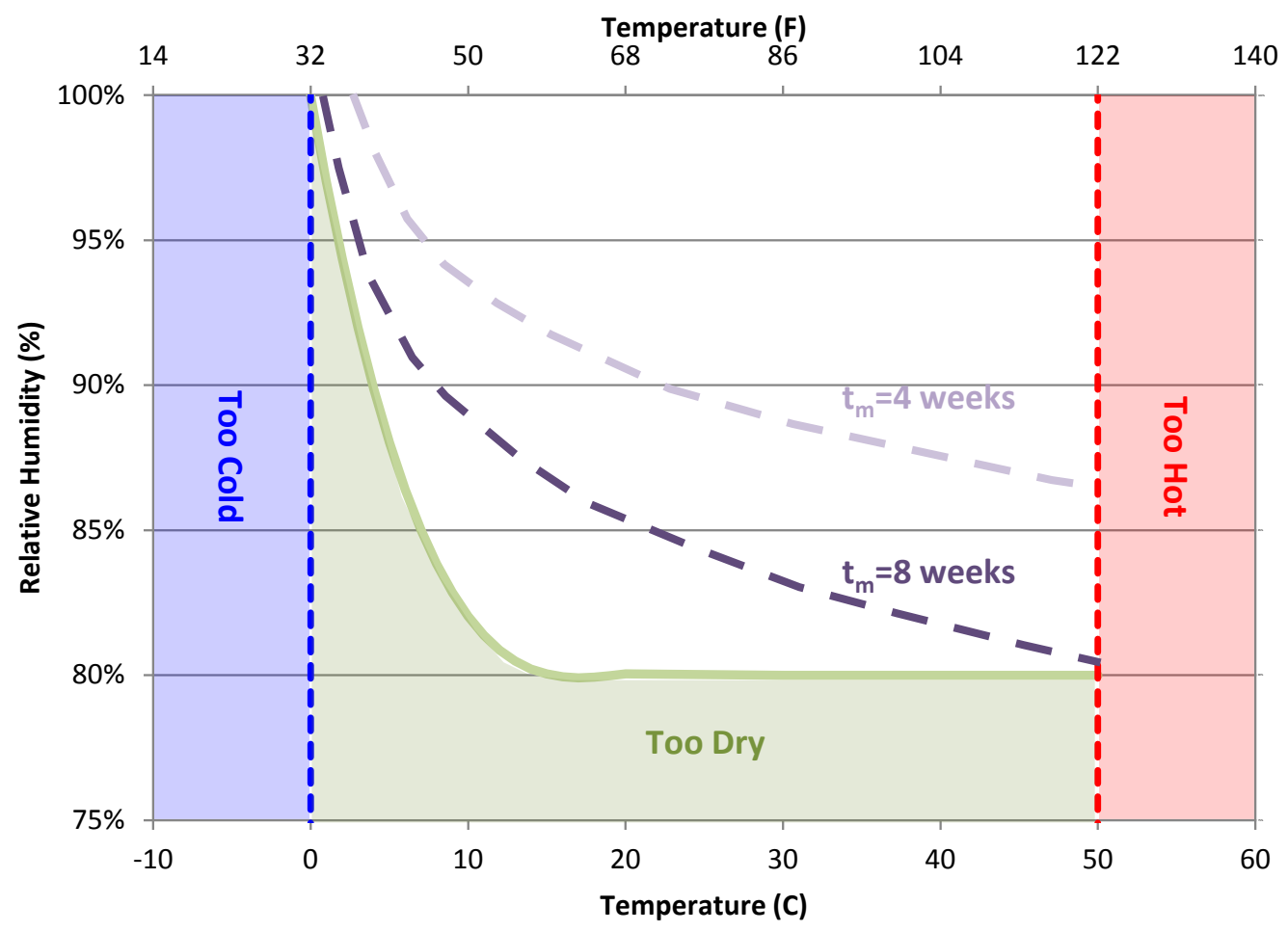

Figure 50. T/RH conditions for mold growth

(Viitanen and Ojanen 2007)

The ASHRAE 160 criteria (RH higher than $80 \%$, temperature between $41^{\circ} \mathrm{F}\left[5^{\circ} \mathrm{C}\right]$ and $104^{\circ} \mathrm{F}$ $\left.\left[40^{\circ} \mathrm{C}\right]\right)$ are also plotted in this manner, superimposed on the Viitanen criteria, in gray in Figure 51.

Another set of mold failure criteria is Sedlbauer's (2004) system of Lowest Isopleth for Mold (LIM) curves for various building material substrates. These limits indicate risk conditions for mold growth, including the LIM $_{\text {Bau }}$ I level (biodegradable materials such as wallpaper, plasterboard) and the LIM $_{\text {Bau }}$ II level (porous substrates such as mineral building materials and some woods). These two curves are plotted in Figure 51, shown in solid gold and brown lines.

Overall, this demonstrates substantial overlap in the various systems of identifying high moldrisk conditions. 


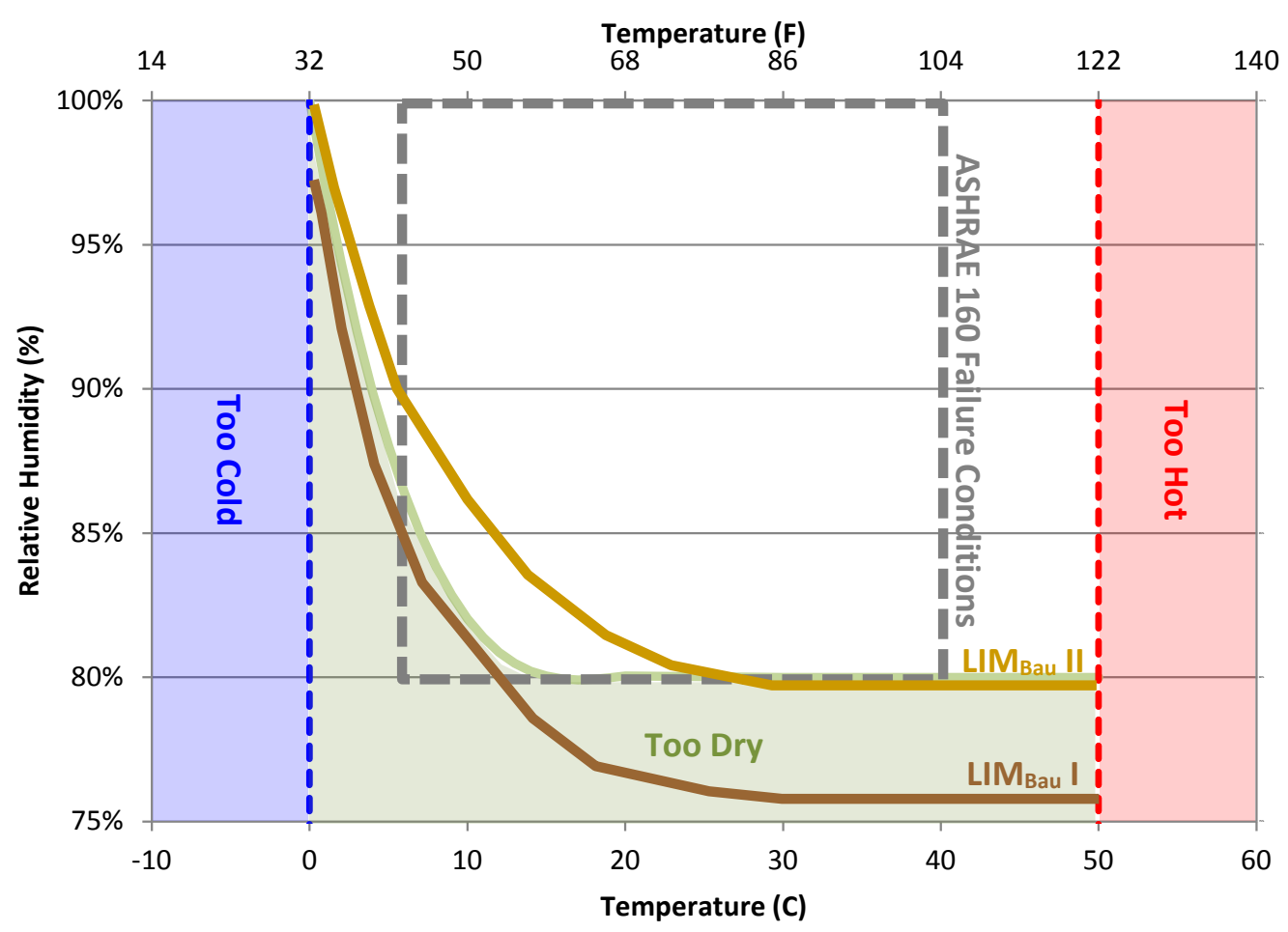

Figure 51. Isopleth example, with Viitanen, ASHRAE 160, and LIM Bau $_{\text {criteria plotted }}$

Data from the high humidity winter (2012-2013) from November through May are plotted on these T/RH scatter plots in the following figures. The temperature and calculated RH (at the insulation-sheathing interface) are used, given that this is the likely substrate/location for mold growth.

The north-facing walls (Figure 52) show many hours with sufficient humidity and temperature to allow mold growth. The ocSPF walls (N1 and N3) have data that are clustered toward the lower risk side of the growth range (immediately to the right of the green curve). However, the cellulose wall (N2) shows a larger number of hours with warmer temperatures and high humidity levels (further to the right of the green curve). This is consistent with the other analysis and measurements described earlier.

The south-facing walls (Figure 53) show a different temperature-RH plot shape caused by solar heating on that orientation. However, as a result, there appear to be more hours spent at higher risk (warmer/high RH) conditions. The cellulose wall (S2) shows many hours at moderate temperatures and very high RHs (95\%-100\%). The ocSPF walls (S1 and S3) have many fewer hours in this high risk range. 

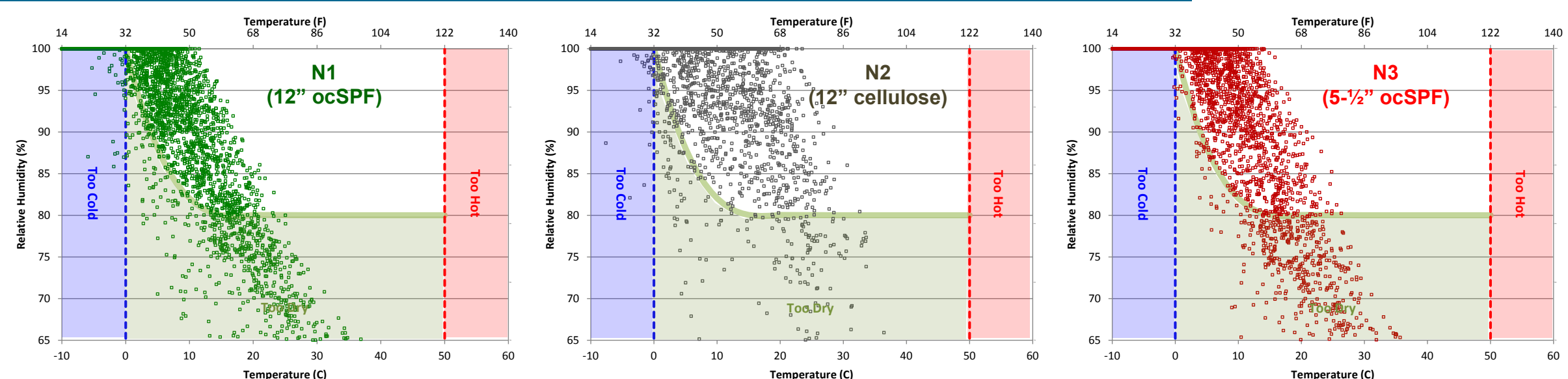

Figure 52. North-facing walls, winter 2012-2013 (November-May) T/RH plots, insulation-sheathing interface
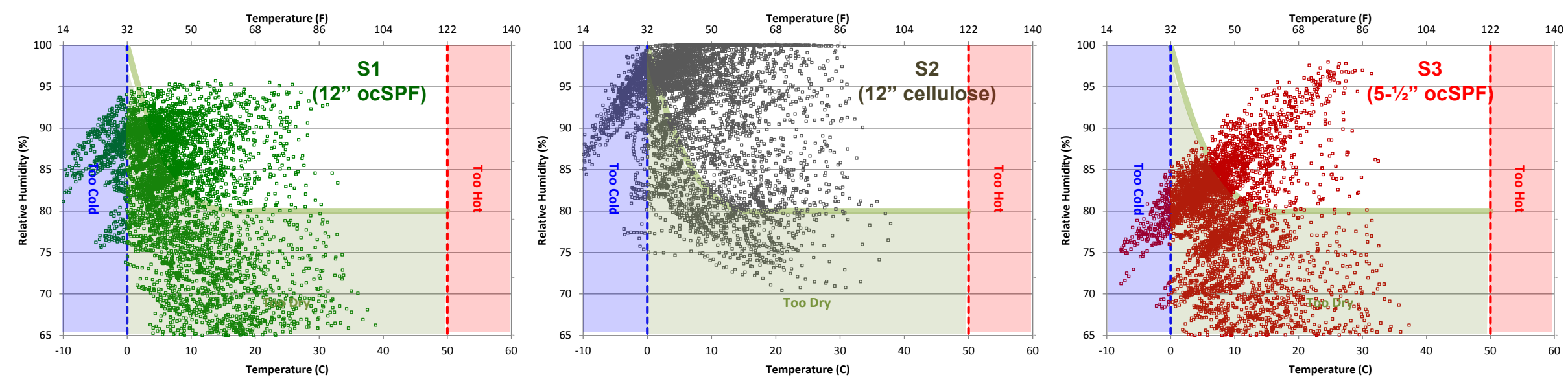

Figure 53. South-facing walls, winter 2012-2013 (November-May) T/RH plots, insulation-sheathing interface 


\subsection{Protective Mechanisms: Overview}

Based on the monitored data, calculations, and analysis, all three walls should be at high risk of failure. High MCs and condensation were measured, especially during the second (high humidity) winter. All of the analytic tools used above indicate that these walls should be failing.

However, disassembly of these walls indicated no sign of significant failure: no visible mold was seen (albeit a nonmagnified assessment), and no significant staining or water rundown was seen in the wall cavity. The most significant signs of damage were slight grain raise of the OSB sheathing surface (in the cellulose walls), and slight rusting of nails and cable staples.

This suggests that the walls, at least in the configurations tested, are far more robust than current analysis tools would indicate; damage was far lower than the monitoring would suggest.

One theory to explain this behavior is that, although the walls underwent significant wetting in the winter, they dried before damage could occur. However, based on ASHRAE 160 analysis and mold isopleths, wet conditions continued into the spring, resulting in conditions warm enough to support mold growth, especially in the cellulose wall.

Another possible explanation lies in the properties of the vulnerable substrate, the OSB sheathing. Fox (2014) notes OSB has some properties that might limit mold risks: the use of wax and adhesive to bind the OSB, the smooth compacted surface, and the higher density (lower porosity) would all tend to reduce moisture uptake, storage, and thus mold risk. In addition, the manufacturer of the OSB used at this site uses only methylene diphenyl diisocyanate (MDI) adhesive, which reduces water uptake. Most OSB manufacturers use a mixture of MDI and phenol formaldehyde adhesives, resulting in higher water uptake at the surface.

However, this contention contradicts many field observations, where OSB is known to be a moisture-vulnerable substrate. Specifically, Lstiburek (2006) notes that OSB is a more vulnerable substrate to mold growth than either plywood or sawn lumber, because faster growing woods and greater exposed surface areas of the strands (flakes) are used. Finally, the lack of visible mold on the wafer (no MDI adhesive or wax) also suggests other mechanisms were at play.

Yet another possibility is that the cavity insulation materials provided a degree of protection to the OSB sheathing surface. Possible mechanisms are discussed in the following sections.

ASHRAE Standard 160 Addendum a (ASHRAE 2011) notes that materials that are naturally resistant to mold, or have been chemically treated to resist mold, might be able to withstand higher RH or longer exposures without damage. It is useful that the standard acknowledges this fact, but without better quantification for a range of materials, the statement is of limited use.

\subsection{Protective Mechanisms: Cellulose Walls}

Cellulose fiber insulation contains borates, which act both as a fire retardant and a preservative. For instance, in the product installed at this site, the cellulose insulation contains $15 \%$ or less (by weight) boric acid and sodium tetraborate pentahydrate; other cellulose insulation manufacturers use ammonium sulfate in this role in conjunction with borates. Previous field observations have provided evidence that these preservatives can migrate into adjacent materials (e.g., sheathing or gyspum board), thus providing them with some protection. 
In addition, cellulose insulation is able to absorb moisture safely, resulting in a moisture storage/buffering effect in an assembly.

Rose and McCaa (1998) observed this type of protective effect in a 3-year in-situ monitoring study of 14 wood frame walls in zone 5A (Champaign, Illinois) with various configurations of cavity insulation, vapor control, and insulation facer attachment. Three walls were configured with only Class III vapor control (latex paint on gypsum board); cavity fill insulation materials were fiberglass batt, blown-in fiberglass, and cellulose (dry-blown behind netting). Interior RH was run at either $50 \%-55 \% \mathrm{RH}$ or $40 \% \mathrm{RH}$ (over multiple winters). These three Class III vapor retarder walls had the highest $\mathrm{MC}$ measurements (both gravimetric and electric resistance) of the test walls. When these three walls were disassembled, the conditions within the cavity were described as follows:

- Fiberglass batt: severe mold growth, evenly distributed on sheathing. Some mold growth on fiberglass.

- Blown-in fiberglass: medium mold growth, even distributed in cavity.

- Cellulose: mild mold growth, severe corrosion on metal fasteners. Caking of cellulose on OSB sheathing.

Although all of these walls failed (i.e., had visible mold growth), these results indicate that cellulose insulation might provide some degree of protection, as evidenced by the milder mold growth under identical boundary conditions. Although cellulose retards airflow, it is not the dominant mechanism at play here. The fact that mold growth is evenly distributed on the sheathing of fiberglass walls indicates that the issue is likely vapor diffusion, as opposed to air leakage (which would manifest as point concentrations of damage).

Carll et al. (2007) monitored eight wood frame walls insulated with sprayed cellulose in a test house in a zone 6A climate (Madison, Wisconsin); wintertime humidities were maintained in the $45 \%-50 \%$ range. A porch soffit was (unintentionally) wetted sufficiently to buckle; however, no mold growth was seen on the wood soffit boards. The authors suggested that the cellulose borate additives might have leached into the wood soffit, providing some protection. Disassembly of a cellulose nontest wall showed mold growth; however, the field observations suggested that the borates might have inhibited the growth of at least some mold species.

Clausen et al. (2009) monitored a wood frame house in zone 6A (Madison, Wisconsin) while maintaining high interior RHs (35\%-50\% through the winter). They observed mold growth at multiple locations, including at the basement rim joist, which was insulated with cellulose and no interior vapor retarder. Mold was found at the interface of the rim joist and insulation (on both materials). The authors reviewed the literature on the use of borates as a preservative. The general conclusion was that they can be effective at certain concentrations against certain species, but not against others.

In the current field research, we found that metal fastener corrosion in the cellulose bays was mild. However, Rose and McCaa (1998) found severe corrosion. The difference is likely the preservative chemistry: in our research, only borate-based cellulose was used, while in the 
Illinois research, ammonium sulfate cellulose was installed. Ammonium sulfate has been linked to greater corrosion damage at high moisture levels.

Overall, the literature suggests that although cellulose treated with borates can increase mold resistance of walls, it is by no means a panacea. The resistance can be overcome with a sufficient loading of moisture. However, it might explain the lack of damage seen in this work.

\subsection{Protective Mechanisms: Open-Cell Spray Polyurethane Foam Walls}

Spray foams in general, and ocSPF (used at this site) appear to provide some resistance to mold growth at the insulation-substrate interface. This has been seen in various instances: for instance, Schumacher and Reeves (2007) measured high moisture contents (20\%-25\%) in roof sheathing in the Pacific Northwest (Vancouver, British Columbia). When a core sample was taken, the sheathing was entirely intact: no signs of mold, decay, structural damage, or water staining were found.

Several theories have been posed for how spray foam might protect the structural sheathing, including:

- Oxygen restriction: the air-impermeable nature of the spray foam might restrict the flow of oxygen to insulation-OSB interface, thus limiting mold growth.

- Flash heating: the installation of spray foam is a highly exothermic process, resulting in high temperatures at the interface. It is plausible that this heating "sterilizes" the substrate surface, killing the mold spores. At that point, the substrate is isolated from innoculation with new spores because of the spray foam.

- Surface treatment (film formation): during application, spray foam forms a film of polyurethane on the substrate, and then expands. It is plausible that this film makes the substrate less amenable to mold growth.

- Capillary redistribution: open-cell foams are known to pass liquid water through the field of the foam. It is possible that the open-cell structure allows for storage of liquid water by capillarity and redistributes the water away from the sheathing.

These theories are discussed in more detail in the following sections:

\subsubsection{Oxygen Restriction}

Mold/fungal growth requires spores, nutrients (substrate), the correct temperature and moisture conditions (discussed above), and air (specifically oxygen) (Clausen 2010). Open cell foam at sufficient thicknesses (e.g., 4-1/2 in. for the ocSPF used at this site) meets the requirements for an air barrier material. Therefore, it seems plausible that the foam restricts oxygen availability to mold spores at the insulation-sheathing interface.

Fungal growth can be inhibited by limited oxygen availability: water-soaked wood, such as piles continuously submerged below the water table, are not vulnerable to decay by wood-decay fungi (Clausen 2010), due to the lack of air/oxygen.

However, Morris (2000) notes that in the context of biodeterioration of wood in structures, oxygen is normally not a limiting factor. For instance, he states that painting or sealing a wood 
surface will not exclude oxygen from the wood. He also notes that wood-rotting fungi are tolerant of low oxygen levels.

The low oxygen requirements are consistent with the food science literature. Miller and Golding (1949) examined the oxygen response of six mold species by varying the partial pressure of oxygen in the growth enclosure atmosphere. They found that mold growth was not significantly inhibited until oxygen concentrations reached $0.3-0.8$ volumes soluble in 1000 volumes of water. Assuming a volumetric calculation, this is equivalent to $300-800$ parts per million (compared to $21 \%$ oxygen by volume in the Earth's atmosphere). They concluded that the oxygen supply must be very low before mold growth inhibition is observed. Furthermore, Brancato and Golding (1951) observed that mold can utilize oxygen dissolved in the substrate/growth medium via absorption through hyphae.

Finally, the structure of ocSPF, compared to ccSPF (Figure 54) suggests that although ocSPF can function as an air barrier, the open cell structure is unlikely to provide a barrier to the slow diffusion of oxygen. However, this matrix would inhibit the spread of mold spores through airborne dispersal.
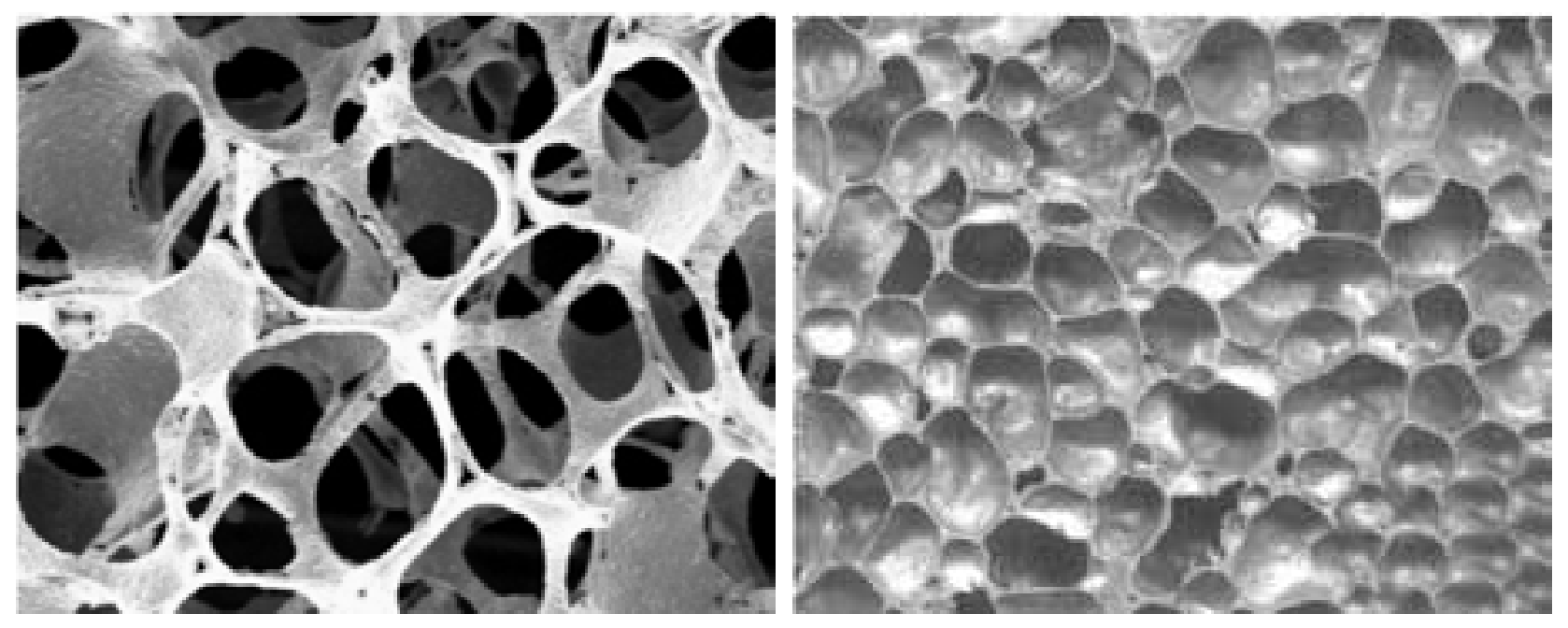

Figure 54. Micrographs of ocSPF (left) and ccSPF (right)

(images courtesy of Spray Polyurethane Foam Alliance)

Based on the literature and these observations, it seems unlikely that the oxygen restriction theory is the active mechanism.

\subsubsection{Flash Heating}

The application of spray foam is an exothermic (heat-generating) process (Figure 55); the foam surface and core temperatures will be a function of ambient temperature and substrate temperature. The spray foam industry warns against spraying foam at thicknesses greater than 2 in. $(50 \mathrm{~mm})$, which can result in trapped heat and excessively high temperatures, thus resulting in poor installation quality and (in extreme cases) fire risks. BASF (2001) warns that ccSPF sprayed excessively thick (4-6 in. [102-152 mm]) can reach temperatures of $200^{\circ}-300^{\circ} \mathrm{F}\left(95^{\circ}-\right.$ $150^{\circ} \mathrm{C}$ ). The Spray Polyurethane Foam Alliance (SPFA 1994) warns that spray foam should not be exposed to temperatures higher than $200 \mathrm{~F}\left(95^{\circ} \mathrm{C}\right)$ in service. 


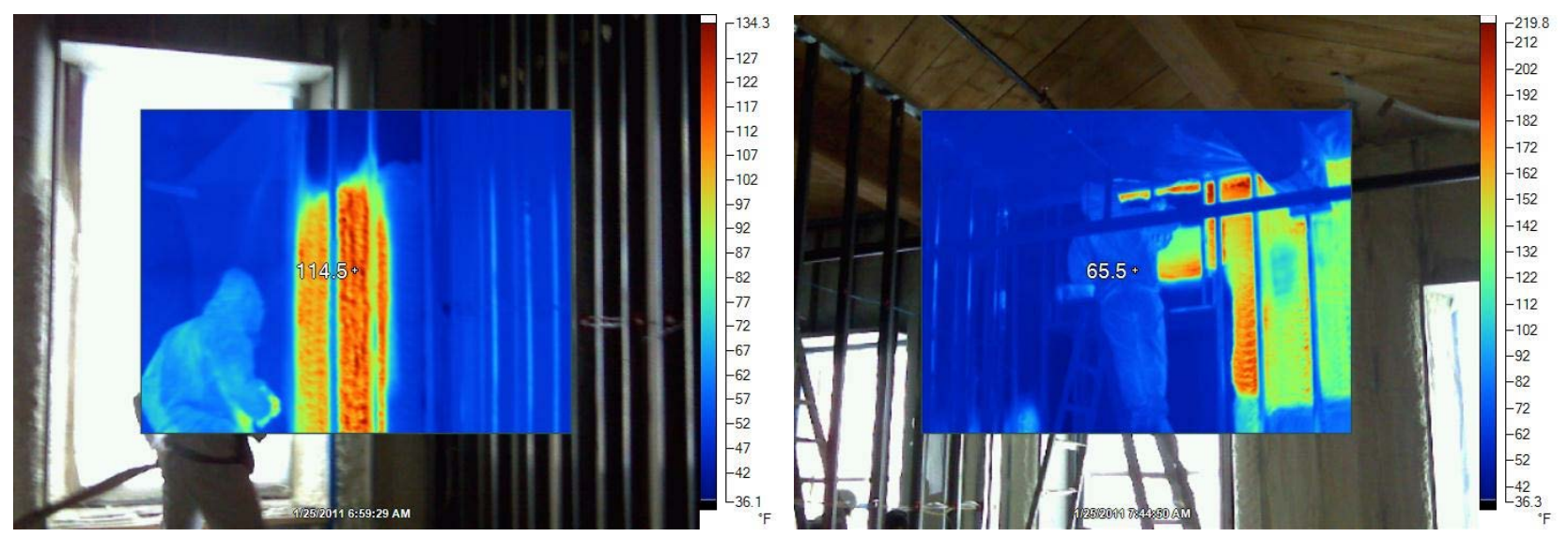

Figure 55. Infrared images of ccSPF application on a mass masonry substrate

These temperatures can be compared with time and temperature exposures required to kill molds (Domsch et al. 1980), as shown in Table 7. Several of the species are stated in terms of "thermal death point," or the shortest length of time required to kill all test microbes at a specified temperature.

Table 7. Sterilization Temperatures Required for Various Mold Species

(Domsch et al. 1980)

\begin{tabular}{c|c|c|c|c}
\hline Genus/Species & Temperature & Time & Growth Medium & Condition \\
\hline Aspergillus niger & $145^{\circ} \mathrm{F}\left(63^{\circ} \mathrm{C}\right)$ & $25 \mathrm{~min}$ & Apple juice & Thermal death point \\
\hline Alternaria alternata & $145^{\circ} \mathrm{F}\left(63^{\circ} \mathrm{C}\right)$ & $25 \mathrm{~min}$ & Apple juice & Thermal death point \\
Aspergillus fumigatus & $145^{\circ} \mathrm{F}\left(63^{\circ} \mathrm{C}\right)$ & $25 \mathrm{~min}$ & $\mathrm{n} / \mathrm{a}$ & "Tolerates up to" \\
Chaetomium globosum & $\begin{array}{c}131^{\circ}-135^{\circ} \mathrm{F} \\
\left(55^{\circ}-57^{\circ} \mathrm{C}\right)\end{array}$ & $10 \mathrm{~min}$ & $\mathrm{n} / \mathrm{a}$ & Thermal death point \\
Cladosporium herbarum & $145^{\circ} \mathrm{F}\left(63^{\circ} \mathrm{C}\right)$ & $30 \mathrm{~min}$ & Apple juice & Thermal death point \\
Stachybotrys chartarum & $\begin{array}{c}122^{\circ}-140^{\circ} \mathrm{F} \\
\left(50^{\circ}-60^{\circ} \mathrm{C}\right)\end{array}$ & $30 \mathrm{~min}$ & Soil & Thermal death point \\
\hline
\end{tabular}

Although these temperatures are within the likely range for spray foam application, it seems doubtful that these high sterilization temperatures would be consistently maintained for such long periods. For instance, wintertime application of foam on a nonthermally massive structural sheathing (e.g., OSB) would quickly shed heat to the exterior. On the other hand, these timetemperature requirements are likely on the conservative side, given the requirement to kill microbes in food products.

Overall, it appears unlikely that flash heating is the active mechanism, although it could be plausible, if shorter exposures to high temperatures significantly reduce mold viability.

\subsubsection{Surface Treatment (Film Formation)}

The spray foam industry posits that when SPF is applied, it forms a thin, dense layer of polyurethane on the substrate. This layer might act as a barrier between the substrate (which would be the source of food and possibly oxygen for the mold) and the mold spores. In other words, it might make the substrate surface less amenable to mold growth. 
Bomberg and Lstiburek (1998) note that polyester and polyurethane foams will not normally support mold growth, including testing of burial of foam in soil. Pure polyurethane is not known to be a food source for mold; in addition, unreacted additives or reaction byproducts could also render the foam matrix less conducive to mold growth. However, no further literature was found to support or refute the theory of surface treatment effects.

\subsubsection{Capillary Redistribution}

ocSPF structure allows the passage of bulk liquid water, as demonstrated in Figure 56.
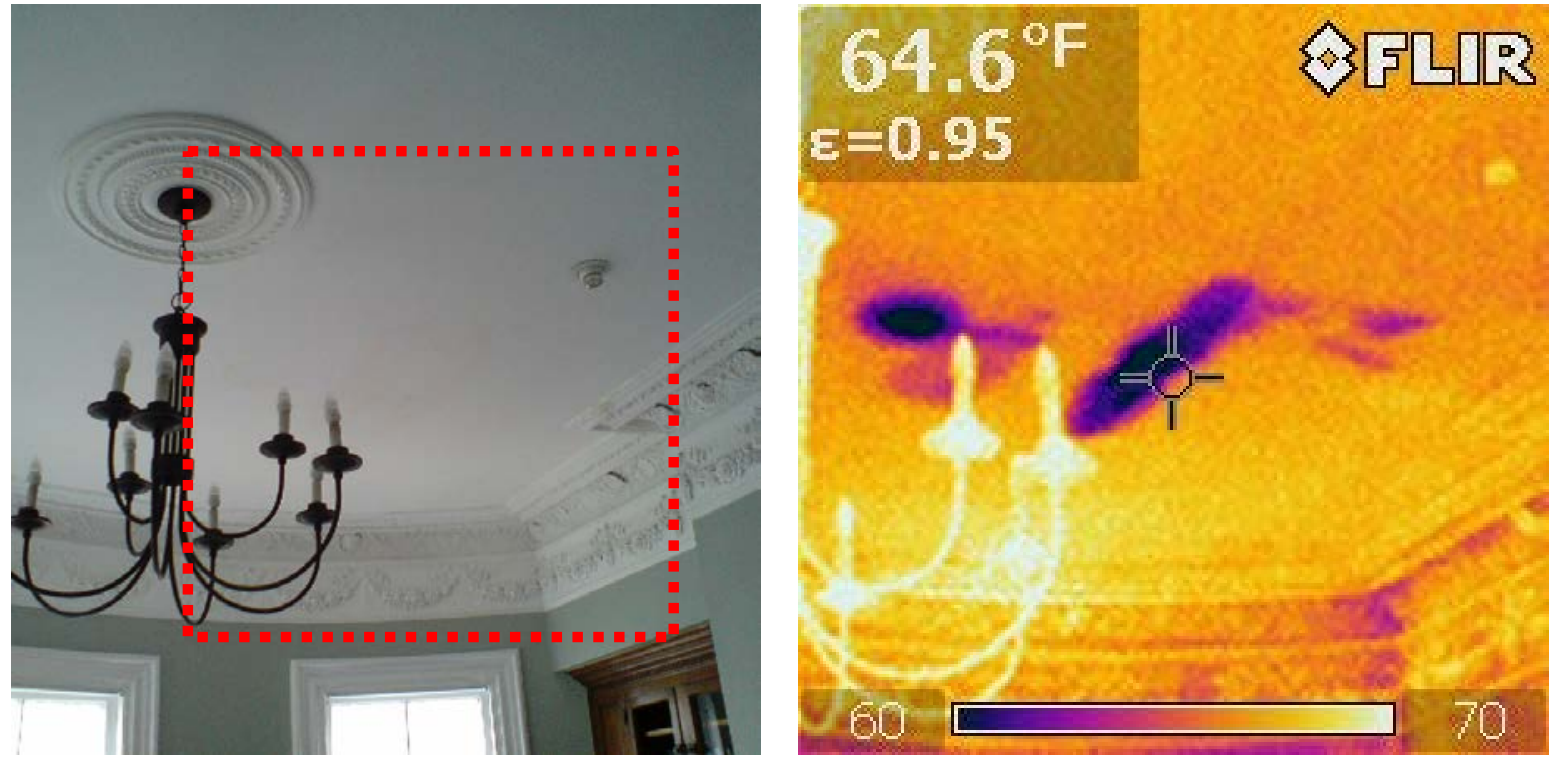

Figure 56. Bulk water leakage through ocSPF, visible at interior

In addition, the open cells should store some water because of capillarity. Safe storage of moisture is a useful attribute for the durability of building enclosure assemblies (Straube and Burnett 2005; Lstiburek 2006).

As a bounding exercise, the capillary uptake that would be associated with the pore size found in spray foams can be calculated. Bomberg and Lstiburek (1998) give a range of cell diameters for several spray polyurethane foam products; they range from $250-500 \mu \mathrm{m}$. Using the equation from Straube and Burnett (2005), the capillary pressure can be calculated as 150-300 Pa (0.6-1.2 in. w.c.). Inches of water column would reflect the height that water would rise vertically in the foam material, but only if the cells were open for capillarity. This suggests that there could be significant storage of water in an ocSPF product. Note that the theory of capillary redistribution would apply to ocSPF only, and not to ccSPF.

However, no further literature was found to support or refute this theory. 


\section{Conclusions and Further Work}

\subsection{Conclusions}

The following conclusions can be drawn from this research project:

- Under "normal" interior conditions in a zone 5A climate (functioning ventilation system, wintertime RH 10\%-30\%), ocSPF walls (both 12 -in. and 5-1/2-in.) with latex paint as interior vapor control (nominally Class III, but possibly more vapor open) showed low risk; all sheathing MCs remained lower than $20 \%$. However, the 12 -in. cellulose wall had MCs exceeding $20 \%$ on the north side. In addition, the cellulose wall sheathing-insulation interface had high RH conditions.

- Under high interior humidity loading (nonfunctional ventilation system, $40 \%-50 \%$ interior RH in a zone 5A climate), all test walls showed MCs and sheathing-insulation interface RHs well into the high risk range. The cellulose walls showed particularly high MCs (sheathing over 30\%), while the ocSPF walls showed MCs in the $18 \%-25 \%$ range. In addition, the monitoring showed evidence of liquid water condensation (which can result in quick degradation) in all walls, the condensation was substantial in the cellulose walls. These condensation issues occurred on both north and south sides.

- In all walls, during each summer after a winter of wetting, moisture levels fell well into the safe range.

- Based on the difference between these two winters, it is clear that interior RH can have a tremendous effect on the performance of enclosure systems, in terms of interstitial condensation risks, when using more vapor-open interior finishes such as latex paint. A more vapor-closed interior layer (e.g., Class II vapor retarder, 1-0.1 perm) would be less vulnerable to interior RH conditions, albeit with a reduction in inward drying.

- The high interior RH was due to airtightness ( $\pm 1 \mathrm{ACH} 50$ construction), high occupant density (family of four), and a nonfunctioning ventilation system. When the ventilation system was put into service, interior RH was brought back to a reasonable level, demonstrating the vital importance of a functional mechanical ventilation system. Given that current energy-efficient construction can now consistently reach these airtightness levels, the risks of high interior RH are greater.

- The ocSPF walls showed consistently lower MCs and interface RH levels than the cellulose walls. Although air leakage cannot be eliminated as a possibility, it is likely that at the thicknesses applied, the ocSPF provided reasonable vapor control (1.5-3.5 perms when combined with Class III latex paint) under normal loading conditions.

- The 12-in. ocSPF wall generally showed higher MCs than the 5-1/2-in. ocSPF wall, but the difference was not dramatic. The common explanation for the greater risks associated with double-stud walls is that the sheathing is colder because of the increase in insulation. The data did not show a substantial difference in sheathing temperatures: instead, the relative amounts of heat/drying energy passing through the sheathing are likely more important than the sheathing temperatures, when comparing typical insulation levels with "super-insulated" assemblies. 
- The collected data were analyzed in terms of ASHRAE Standard 160 criteria (tabulating hours with RH and temperatures that support mold growth), using the calculated surface $\mathrm{RH}$ at the sheathing-insulation interface. All north-facing walls failed through all three winters; in particular, there were large numbers of failure hours during the high humidity winter (2012-2013). On the south side, all three walls failed during the high humidity winter, but passed during other winters.

- When sheathing-insulation interface temperatures and RHs for the high humidity winter are plotted, many hours show risk conditions above the mold risk isopleth lines (high humidity and sufficient temperature for mold growth).

- When the walls were disassembled at the conclusion of the experiment, the sheathing and framing showed remarkably little evidence of wetting damage or mold growth. No visible mold growth (unmagnified) or evidence of staining or water rundown was found. The damage was limited to some limited grain raise of the interior surface of the OSB at the cellulose wall, and slight corrosion of fasteners and staples.

- Based on the monitored data, calculations, and analysis, all three walls should have been at high risk of failure; the analytic tools used indicate that these walls should have failed. However, disassembly showed that the walls were essentially undamaged by the monitored moisture exposure. This suggests that the walls, at least in the configurations tested, were far more robust than current analysis tools would indicate. This is additional evidence that the failure criteria in ASHRAE Standard 160 are overly conservative. Various theories were proposed on what protective mechanisms might be at work in these assemblies; one possible explanation was that the OSB used at this site has low moisture absorption because of adhesive formulation.

- The cellulose walls are likely protected by borate preservatives (which inhibit mold) and the ability to safely store moisture. However, the literature shows that although boratetreated cellulose can have significant mold-inhibiting effects, it is not a panacea. If the moisture loading is sufficiently high, mold will grow.

- The protective mechanism of the ocSPF wall was not clear. Proposed theories included restriction of oxygen to the sheathing-insulation interface, flash heating of the surface during spray foam application (thus sterilizing the interface), coating of the substrate surface with a polyurethane film (thus rendering the wood inaccessible to mold), and capillary redistribution of moisture. Based on resources in the literature, the oxygen theory seems unlikely, given the low oxygen requirements of mold. Similarly, the flash heating theory seems unlikely: the time required to sterilize samples is longer than would occur during installation. Surface treatment and capillary redistribution seem to be plausible explanations; however, no conclusions can be drawn as to whether they are actually the active mechanism without further research.

\subsection{Recommendations for Construction}

Based on the monitoring, it appears that both ocSPF and cellulose double-stud walls will experience exceedingly high moisture levels in zone 5A, during high interior wintertime $\mathrm{RH}$ loadings $(40 \%-50 \% \mathrm{RH})$, with a Class III vapor retarder (latex paint). However, disassembly demonstrated that the walls appeared to be largely unaffected by this wetting. But, for the purposes of recommendations for industry, a more conservative approach is warranted. This is 
particularly true because it appears that these specific test walls were protected by some mechanisms of the cavity fill insulation or sheathing. This degree of safety cannot be guaranteed in slightly different assemblies (e.g., slightly more vapor permeable ocSPF, slightly more moldsensitive or vapor-closed OSB sheathing).

The cellulose walls clearly showed the highest moisture accumulation: the use of interior vapor control more restrictive than Class III (latex paint) is recommended. Other practitioners (NAHB 2010) have found latex paint on gypsum board with vapor permeability much higher than Class III (40 perms, versus 10 perm requirement). A Class II vapor retarder (1-0.1 perm; e.g., variable permeability membrane or vapor retarder paint) will reduce moisture risks to more reasonable levels. However, it is entirely likely that many double-stud walls insulated with cellulose with only Class III vapor control perform well. A Class I vapor retarder (polyethylene) is not recommended because it completely eliminates inward drying.

The ocSPF walls had less moisture accumulation than the cellulose walls; it is a marginal judgment call whether a Class II vapor retarder is needed or warranted. The ocSPF material, at the thickness applied, provides reasonable vapor control (2.0-2.5 perms in 12-in.). The use of a Class II vapor retarder would definitely be conservative, but the double-stud walls insulated with ocSPF have a history of providing excellent performance in this builder's houses.

These recommendations are based on this field research in zone 5a; in colder climate zones (zone 6 or 7), different materials or assemblies might be required.

As discussed earlier, a functional mechanical ventilation system is critical for enclosure durability in modern high performance construction in cold climates, especially if more vapor permeable interior finishes are used. Given the greater risks in high performance constructionas demonstrated in this project (airtightness, high occupancy, inoperative ventilation) — erring on the conservative side for wall design may be prudent.

As demonstrated in the literature and recent research (Fox 2014), insulation outboard of the sheathing substantially reduces risks of interstitial condensation from interior-sourced air leakage, or vapor flow (with more vapor-open interior finishes such as latex paint). Exterior insulated walls have much higher intrinsic moisture safety than thick cavity walls such as double-stud walls.

\subsection{Further Work}

The builder involved in this research project (Transformations, Inc.) is currently pursuing a NYSERDA grant to perform long-term (3-year) moisture monitoring of double-stud walls with cellulose insulation in Northampton, Massachusetts. Given the budget provided by NYSERDA ( $\$ 2,000$ per house), only limited monitoring can be conducted. Building Science Corporation suggested that the maximum scope within that budget might be tracking of interior and exterior conditions, and periodic (monthly or bimonthly) spot checks of sheathing conditions with a handheld moisture meter.

Another area worth further study is the mechanisms that reduce mold risks when using ocSPF and cellulose cavity insulations. Specifically, quantifying their increased resistance to mold growth would be useful for expanding the failure threshold used in standards such as ASHRAE 
160. In particular, the mechanism at work in the ocSPF wall could be studied with climate chamber and benchtop laboratory testing. For instance, the "flash heating" theory could be tested by comparing viable mold spore counts before and after spray foam installation. The capillary storage theory could be tested by saturating the sheathing-insulation interface in a climate chamber and performing gravimetric MC measurements to demonstrate storage capacity. Micrographs of the foam-substrate interface might provide more information on whether the "surface film" effect is significant. 


\section{References}

Arena, L.; Owens, D.; Mantha, P. (2013). "Measured Performance of an R-40 Double-Stud Wall in Climate Zone 5A." Buildings XII Conference Proceedings. Atlanta, GA: American Society of Heating, Refrigerating and Air-Conditioning Engineers, Inc.

Arena, L. (2014). “ASHRAE 160: Modeling and Measured Data.” Building America Expert Meeting 2014: Guidance on Modeling Enclosure Design in Above Grade Walls. Accessed January 2015: http://www.buildingscience.com/documents/bareports/ba-1403-guidancemodeling-enclosure-design-above-grade-walls-expert-meeting/view.

ASHRAE. (2009a). 2009 ASHRAE Handbook-Fundamentals. Atlanta, GA: American Society of Heating, Refrigerating and Air-Conditioning Engineers, Inc.

ASHRAE. (2009b). ANSI/ASHRAE Standard 160-2009: Criteria for Moisture-Control Design Analysis in Buildings. Atlanta, GA: American Society of Heating, Refrigerating and AirConditioning Engineers, Inc.

ASHRAE. (2011). ANSI/ASHRAE Standard 160-2009: Criteria for Moisture-Control Design Analysis in Buildings: Addendum a. Atlanta, GA: American Society of Heating, Refrigerating and Air-Conditioning Engineers, Inc.

BASF. (2001). "WALLTITE® - Polyurethane Spray Application Guide.” Accessed January 2015: http://www2.basf.us/basf-canada/productsheets/walltite/wltspray-E.pdf.

Bergey, D.; Ueno, K. (2011). "New England Net Zero Production Homes.” 2011 ASHRAE Annual Conference, Montreal, QC, Canada, June 25-29, 2011.

Bomberg, M.; Lstiburek, J. (1998). Spray Polyurethane Foam in External Envelopes of Buildings. Boca Raton, FL: CRC Press.

Brancato, F.; Golding, N.S. (1951). "Gas Requirements of Molds: The Importance of Dissolved Oxygen in the Medium for Germination and Growth of Several Molds." North W. Sci. 27 33-38.

Carll, C.G.; Highley, T.L. (1999). "Decay of Wood and Wood-Based Products Above Ground in Buildings. Journal of Testing and Evaluation 27(2):150-158.

Carll, C.; TenWolde, A.; Munson, R. (2007). "Moisture Performance of a Contemporary WoodFrame House Operated at Design Indoor Humidity Levels.” Buildings X Conference Proceedings. Atlanta, GA: American Society of Heating, Refrigerating and Air-Conditioning Engineers, Inc.

Clausen, C.; Glaeser, J.; Glass, S.; Carll, C. (2009). Occurrence of Mold in a Two-Story WoodFrame House Operated at Design Indoor Humidity Levels. Forest Products Laboratory General Technical Report FPL-GTR-186. Madison, WI: USDA Forest Products Laboratory. 
Clausen, C. (2010). Wood Handbook: Wood as an Engineering Material - Chapter 14, Biodeterioration of Wood. General Technical Report. FPL-GTR-190, Madison, WI: U.S. Department of Agriculture, Forest Products Laboratory.

Coldham, B. (2010). "Six Proven Ways to Build Energy-Smart Walls." Fine Homebuilding Magazine, January 2010, pp. 68-73. Newtown, CT: Taunton Press.

Cushman, T. (2014). "Studying Moisture in Fat Walls." Journal of Light Construction, June 2014, pp.37-38. Washington, DC: Hanley-Wood LLC.

Derome, D. (2005). "Moisture Accumulation in Cellulose Insulation Caused by Air Leakage in Flat Wood Frame Roofs." Journal of Thermal Envelopes \& Building Science, Vol. 28, No. 3January 2005.

Doll, C.S. (2002). Determination of Limiting Conditions for Fungal Growth in the Built Environment, PhD Thesis, Harvard School of Public Health.

Domsch, K.; Gams, W.; Anderson, T. (1980). Compendium of Soil Fungi. New York: Academic Press/Harcourt Brace Jovanovich, Publishers.

Fox, M. (2014). "Hygrothermal Performance of Highly Insulated Wood Frame Walls With Air Leakage: Field Measurements and Simulations." Master of Applied Science Thesis, Ryerson University. Accessed January 2015: http://newbuildscanada.ca/wpcontent/uploads/2013/06/Michael-Fox-M-A-Sc-Thesis-May7.pdf.

Glass, S.V.; Zelinka, S.L. (2010).Wood Handbook: Wood as an Engineering Material Chapter 4, Wood as an engineering material. General Technical Report. FPL-GTR-190, Madison, WI: U.S. Department of Agriculture, Forest Products Laboratory.

Glass, S.V. (2013). Hygrothermal Analysis of Wood-Frame Wall Assemblies in a Mixed-Humid Climate. Research Paper FPL-RP-675. Madison, WI: U.S. Department of Agriculture, Forest Service, Forest Products Laboratory.

Holladay, M. (2013). "Musings of an Energy Nerd: Monitoring Moisture Levels in Double-Stud Walls." Green Building Advisor.com. Accessed January 7, 2014: http://www.greenbuildingadvisor.com/blogs/dept/ musings/monitoring-moisture-levelsdouble-stud-walls.

ICC. (2009). International Residential Code for One-And Two-Family Dwellings. Country Club Hills, IL: International Code Council.

Ireton, K. (2013). "The Future of Housing in America." Fine Homebuilding Magazine, Spring/Summer 2013, pp. 74-79. Newtown, CT: Taunton Press.

James, W.L. (1988). Electric Moisture Meters for Wood. General Technical Report FPL-GTR-6. Madison, WI: U.S. Department of Agriculture, Forest Service, Forest Products Laboratory. 
LePage, R.; Schumacher, C.; Lukachko, A. (2013) Moisture Management for High R-Value Walls. (Building America Report - 1316). Accessed January 9,

2014: http://www.buildingscience.com/documents/bareports/ba-1316-moisture-management-forhigh-r-value-walls/view.

Lstiburek, J.W. (2005). "Understanding Air Barriers.” ASHRAE Journal 47:24-30, July 2005. Atlanta, GA: American Society of Heating, Refrigerating and Air-Conditioning Engineers, Inc.

Lstiburek, J.W. (2006). “The Mold Explosion: Why Now?” Fine Homebuilding Magazine, December 2006, pp. 71-75. Newtown, CT: Taunton Press.

Lstiburek, J.W. (2008). "Building Sciences: Energy Flow Across Enclosures.” ASHRAE Journal 50:60-65. Atlanta, GA: American Society of Heating, Refrigerating and Air-Conditioning Engineers, Inc.

Lstiburek, J.W. (2010). “Building Sciences: Don't Be Dense.” ASHRAE Journal 52:54-57. August 2010. Atlanta, GA: American Society of Heating, Refrigerating and Air-Conditioning Engineers, Inc.

Miller, D.; Golding, N.S. (1949). "The Gas Requirements of Molds v. The Minimum Oxygen Requirements for Normal Growth and for Germination of Six Mold Cultures." Journal of Dairy Science, Volume XXXII, February, 1949 Number 2.

Morris, P.I. (2000). “Understanding Biodeterioration of Wood in Structures.” Forintek and British Columbia Building Envelope Council.

NAHB Research Center. (2010). Moisture Performance of Wood-Based Sheathing on Exterior Walls Clad With Absorptive Materials. Report prepared for U.S. Forest Products Laboratory and U.S. Department of Housing and Urban Development. Accessed January

2015: http://www.toolbase.org/pdf/casestudies/moistureperformancewoodbasedsheathing.pdf.

Rose, W.; McCaa, D. (1998). “Temperature and Moisture Performance of Wall Assemblies With Fiberglass And Cellulose Insulation." (pp. 133-144). Proceedings: Thermal Performance of the Exterior Envelopes of Buildings VII. (ISBN 1-883413-70-2). Atlanta, GA: American Society of Heating, Refrigerating and Air-Conditioning Engineers, Inc.

Schumacher, C.; Reeves, E. (2007). "Field Performance of an Unvented Cathedral Ceiling (UCC) in Vancouver." Buildings X Conference Proceedings. Atlanta, GA: American Society of Heating, Refrigerating and Air-Conditioning Engineers, Inc.

Sedlbauer, K. (2004). Prediction of Mould Fungus Formation on the Surface of and Inside Building Components. PhD Thesis, Fraunhofer Institute for Building Physics, 2004.

SPFA. (1994). "Spray Polyurethane Foam for Residential Building Envelope Insulation and Air Seal.” SPI Stock Number AY 112. Fairfax, VA: Spray Polyurethane Foam Alliance. 
Straube, J.; Onysko, D.; Schumacher, C. (2002). "Methodology and Design of Field Experiments for Monitoring the Hygrothermal Performance of Wood Frame Enclosures." Journal of Thermal Envelope and Building Science 26(2): 123-151.

Straube, J.; Smegal, J. (2009). Building America Special Research Project: High-R Walls Case Study Analysis (Building America Report 0903). Accessed January

2015: http://www.buildingscience.com/documents/bareports/ba-0903-building-america-specialresearch-project-high-r-walls.

Straube, J.F.; Burnett, E.F.P. (2005). Building Science for Building Enclosure Design. Building Science Press: Westford, MA.

Tauer, J. (2012). “Installing Dense-Pack Cellulose.” Journal of Light Construction, October 2012. Williston, VT: Hanley Wood, LLC.

Ueno, K.; Straube, J. (2008) "Laboratory Calibration and Field Results of Wood Resistance Humidity Sensors.” Proceedings of BEST 1 Conference, Minneapolis, June 10-12, 2008.

Ueno, K.; Wytrykowska, H.; Bergey, D. (2013). Partnering to Build Net-Zero Energy Houses in Massachusetts. Accessed January

2015: http://www.buildingscience.com/documents/bareports/ba-1303-new-england-net-zeronew-construction-evaluations/view. Somerville, MA: Building Science Corporation.

Viitanen, H.; Ojanen, T. (2007). "Improved Model to Predict Mold Growth in Building Materials.” Buildings X Conference Proceedings. Atlanta, GA: American Society of Heating, Refrigerating and Air-Conditioning Engineers, Inc.

Wagner, R. (2012). "Energy Smart Details: Double-stud walls.” Fine Homebuilding Magazine, June/July 2012, pp. 82-83. Newtown, CT: Taunton Press. 
buildingamerica.gov 